\title{
5. CHRONOSTRATIGRAPHY AND ECOSTRATIGRAPHY OF CRETACEOUS FORMATIONS RECOVERED ON DSDP LEG 47B, SITE 398
}

\author{
J. Sigal, Institut Français du Pétrole, Rueil-Malmaison, France
}

\section{INTRODUCTION}

Hole 398D is located $200 \mathrm{~km}$ off the coast of Portugal (west of Oporto), in a small bathyal platform on the lower continental rise on the southern margin of Vigo Seamount. The hole was drilled on the western flank of a deep northeast-southwest trough in a region considered part of the continental passive margin of the eastern North Atlantic. Drilled in a water depth of 3910 meters, the hole bottomed at 1740 meters and was cored almost continuously downwards from Core $19(585 \mathrm{~m})$, with especially good recovery, in the Mesozoic series between Core $41(800 \mathrm{~m})$ and the basal Core 138 .

This report attempts to date the formations encountered between 800 meters and the bottom of the hole at 1740 meters (Figure 1), and to reconstruct their sedimentary history. Sampling and methods have been organized accordingly.

We sampled extensively because of the unique opportunity afforded by the sequential nature of the deposits, in order to provide a statistical basis for these studies. Multiple samples were obtained from the same or a similar lithologic interval in a sequence; certain sequences were closely sampled several times. A total of 1073 samples was collected.

The various components, organic and inorganic, found in the washed residues (on a 63-micron sieve) were estimated semiquantitatively as to their concentration (absent, trace, rare, common, abundant, and very abundant) and their frequency (sporadic, frequent, and permanent). This applies to calcareous benthos $(\beta)$, agglutinated benthos (AP), planktonics $(\pi)$, radiolarians (Rad), quartz, and mica. A more elementary scale (absent, present, abundant) was used for some other components (organic debris, aptychus, inoceramus, fish remains, plant debris, pyrite, and glauconite). Only the "presence" of ammonites, ostracodes, or spicules was noted. Lastly, the hydrochloric acid reaction of small fragments of sediments discerned under the microscope was tested (calcareous, argillo-calcareous, and noncalcareous).

All these data have been entered on the left (Column B) and the right (Columns $\mathrm{H}, \mathrm{J}$ ) sides of a large stratigraphic range chart (Chart $1 \mathrm{~A}$, microfiche in back pocket, this volume). On its left border (Column A), this chart provides a complete listing of the samples examined. In the middle of this chart, the identified species and/or genera were recorded in the stratigraphic order of their first occurrence (with a larger black dot if particularly abundant). From left to right: the first column (Column C) corresponds to the so-called "primitive arenaceous foraminifers" (AP), which are generally considered residual forms after dissolution processes beneath the CCD; the second large column (Column D) corresponds to the main or most interesting species which serve to establish the biozonation and the age; the third column (Column E) corresponds to a certain number of genera which were not noted in the true biostratigraphic Columns D or C, but whose presence serves to reconstitute the biocoenoses; some of them, on the left side of Column E, also belong to the residual agglutinated group. Two other columns give the results of the analysis of the foraminiferal assemblages (F) and the sedimentary lithofacies $(G)$.

Foraminiferal assemblages were classified according to the presence, absence, or predominance of their three main components: $\beta, \pi$, and AP (as noted above). To visualize the nature of these assemblages and to shorten our text, we propose the following abbreviations:

\begin{tabular}{|c|c|c|c|c|c|}
\hline & & & Assemblages & & $\begin{array}{c}\text { Kinds of } \\
\text { Assemblages }\end{array}$ \\
\hline \multirow{2}{*}{$\beta \geqslant \mathrm{AP}$} & \multicolumn{2}{|r|}{$\pi \neq 0$} & $\mathrm{~A} / \beta$ & & \multirow{2}{*}{$\mathrm{T} / \beta$} \\
\hline & \multicolumn{2}{|r|}{$\pi=0$} & $\mathrm{~A} / \beta^{\prime}$ & & \\
\hline \multirow{2}{*}{$\mathrm{AP}>\beta$} & $\beta=0$ & $\left\{\begin{array}{l}\pi \neq 0 \\
\pi=0\end{array}\right.$ & $\begin{array}{l}\mathrm{A} / \mathrm{PAP} \\
\mathrm{A} / \mathrm{AP}^{\prime}\end{array}$ & & \multirow{2}{*}{$\mathrm{R} / \mathrm{AP}$} \\
\hline & $\beta \neq 0$ & $\left\{\begin{array}{l}\pi \neq 0 \\
\pi=0\end{array}\right.$ & $\begin{array}{l}\mathrm{A} / \mathrm{AP} \beta \\
\mathrm{A} / \mathrm{AP} \beta^{\prime}\end{array}$ & & \\
\hline \multirow{2}{*}{$\mathrm{AP}=\beta=0$} & $\pi \neq 0$ & $\begin{array}{l}\operatorname{Rad} \neq 0 \\
\operatorname{Rad}=0\end{array}$ & $\begin{array}{l}\mathrm{A} / \mathrm{P} 1 \\
\mathrm{~A} / \mathrm{P} 2\end{array}$ & $\mathrm{~A} / \mathrm{P}$ & \multirow{2}{*}{$\begin{array}{l}\text { without } \\
\text { benthos }\end{array}$} \\
\hline & $\pi=0$ & $\begin{array}{l}\operatorname{Rad} \neq 0 \\
\operatorname{Rad}=0\end{array}$ & $\begin{array}{l}\mathrm{A} / \mathrm{Az} 1 \\
\mathrm{~A} / \mathrm{Az} 2\end{array}$ & $\mathrm{~A} / \mathrm{Az}$ & \\
\hline
\end{tabular}

where, $\mathrm{A}=$ assemblage, $\mathrm{T}=$ turbidite, $\mathrm{R}=$ residual, $\mathrm{P}=$ plankton, and $\mathrm{Az}=$ azoic.

Some sedimentary units (I to V) or sub-units will be discussed in the ecostratigraphy section of this report. The designation of sedimentary units and sub-units described in this report are unique to this study and do not apply to the designations provided by the shipboard sedimentologists. These sedimentary units comprise lithologic entities (here called lithoterms) which were partially described onboard ship and upon which we further elaborated at Lan.ont-Doherty Geological Observatory. The different lithoterms in a given unit roughly correspond to the successive intervals, which are usually distinguished in a sedimentary graded sequence. They have been designated differently, depending on the different units $(1,2,3 \ldots$. I, II, III . . . , A, B, C. . .). In the caption of Column G of Chart 1A (back pocket, this volume), these letters and Arabic or Roman numbers have been inserted from one unit to 


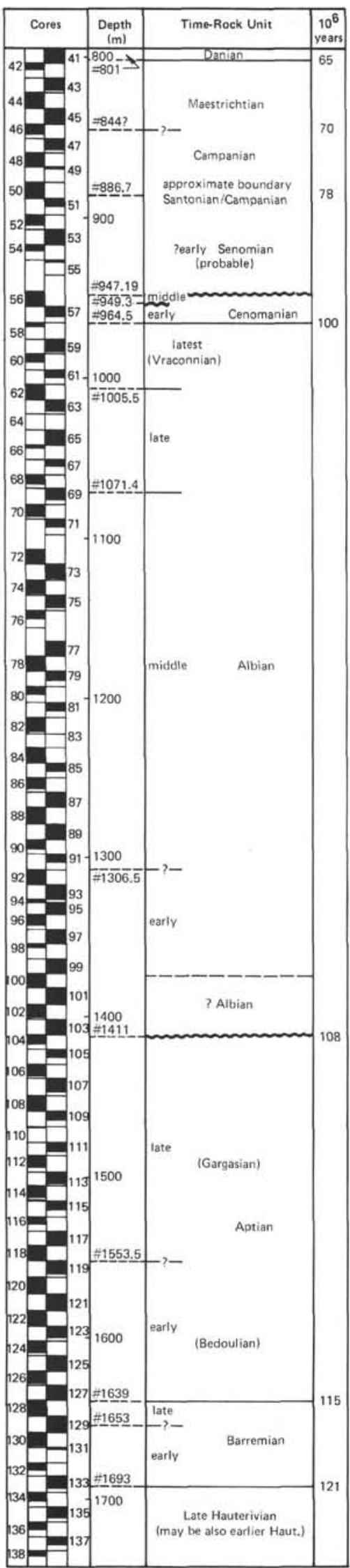

Figure 1. Chronostratigraphic column from Hauterivian to Danian, DSDP Hole 398D. another, keeping in mind that they designate successive homologous deposits. Of course, the final lithoterm, which is equivalent to the upper interval of a sequence, is not exactly identical lithologically if we compare two different units, e.g., Unit I from Cores 138 to 131 (Figure 2) and Sub-units IIa and IIb from Cores 130 to 117 (Figure 3), particularly according to the respective position of the ocean floor and the CCD. However, in this example, whether rich or poor in carbonate, its geological meaning remains the same, i.e., the deposit corresponding to the upper interval of a sequence. In Chart 1A, such homologous lithoterms have been put in vertical superposition from unit to unit.

The analytical results of foraminiferal content and lithologic nature (Columns $F$ and $G$, respectively, in Chart 1 at the end of this volume) have been synthesized in two smaller, more convenient tables. The first one (Table 1, in back pocket, this volume) is a conventional stratigraphic range chart for guide fossils. In the second one (Table 2 , in back pocket, this volume) symmetric curves depict the variations, core by core, of the average amount of the different faunal components, i.e., calcareous benthos, residual benthos, and planktonics, according to their position in the lower (transported sediments) or upper parts (hemipelagites) of the sedimentary sequences. Table 2 also indicates amount

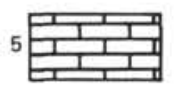

"pelagic" nannofossil-radiolarian limestone in beds of 10 to $30 \mathrm{~cm}$ gradational upper and basal contacts

massive, intensely burrowed, current scours

white to light gray, or bluish white

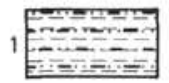

mudstone to claystone, sometimes very argillaceous

mostly laminated, sometimes cross-bedded

frequently burrowed, sometimes graded

frequently splintered

dark to dark gray

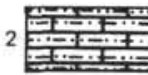

turbiditic mudstone to limestone

fine stratified beds of light-colored debris

sometimes burrowed

light gray to greenish gray

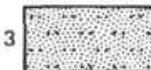

clastic terrigenous quartzose sandstone to siltstone generally well-stratified,

coarse structure, organic debris, gravels of Lithoterm 5

dark gray to greenish gray

Figure 2. Lithologic sequence of reference for Cores 138 to 131 of Hole $398 D$.

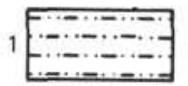

mudstone or claystone, carbonate-depleted, "hemipelagic" homogeneous or slightly burrowed dark gray, black, or greenish black

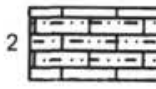

mud-chip sand- to silt-size mudstone carbonate-rich

frequently burrowed

light gray to light olive-gray

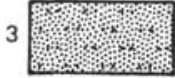

terrigenous quartzose sandstone to silty mudstone graded to cross-bedded

limestone fragments, organic debris, mudclasts gray to multicolored

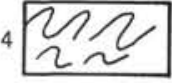

mud flows and debris flows

usually no grading, slump or chaotic structures enclosed packs of Lithoterms 1 to 3

Figure 3. Lithologic sequence of reference for Cores 130 to 117 of Hole $398 D$. 
of radiolarians, plant debris, and pyrite. The presence of aragonitic epistominas, perceptible traces of dissolution on Epistomina shells and on other foraminifers, and reworked material are also reported.

The values indicated by the "curves" or zig-zag lines on Tables 1 and 2 can be considered neither singly nor as a calculated exact datum for a given sample or core. Similarly, the "curves" themselves cannot be interpreted as continuous expressions of the various values which a given organic or inorganic component would assume successively. As indicated above, the amount of a given component has been estimated only in a semiquantitative manner and has not been measured or calculated. Moreover, because of the repetitive character of the strata, these successive estimated values for a given component do not refer to sediments which might have been deposited under similar geological conditions. As has been explained, the samples have been taken repeatedly in either similar or different lithoterms. As a consequence, the "curves" do not link together successive homologous values, rather they link successive values which follow each other in no particular order. Thus, these "curves" must be interpreted in a statistical manner, as an expression of overall evolutive tendencies.

The remainder of this report is divided into two subject areas: chronostratigraphy and ecostratigraphy of Lower Cretaceous formations. The first section comprises biostratigraphical findings (Figure 1, Table 1); the second section discusses the relationship between faunal assemblage and lithology (Figures 2 through 6, Table 2). This report concludes with a synthesis for the geological and sedimentary evolution at the drill site.

Laboratory techniques involved washing the sediment samples with $\mathrm{H}_{2} \mathrm{O}_{2}+$ ammonium, cleaning with Calgon, and screening with a 63-micron sieve. Microphotographs were made with a scanning microscope (CAME BAX) by Mr. M. Bisiaux under the supervision of Mme. M.-Th. Chenebaux (French Petroleum Institute).

\section{CHRONOSTRATIGRAPHY}

Foraminiferal assemblages were collected from the upper Hauterivian to the top of the Upper Cretaceous. Because of the nature and structure of the deposits, the stratigraphic succession observed does not contain the complete set of biozones which is usually distinguished during this time span (see Introduction, this volume).

First, the nature of sediments (pelagic deposits, mainly produced below the CCD) does not favor the preservation of microfossils; accordingly, many guide fossils are reported as absent, especially among planktonic species.

Secondly, the structure of the sediments (heterogeneous, owing to their turbiditic origin, with flow deposits and graded sequences, or with a permanent diffuse and sorted supply) is responsible for the incongruous composition of the assemblage or for its rapid change from bed to bed.
Thus attention must always be focused on these qualitative alterations in the sediments to determine which species of these allochthonous populations have actually been reworked from older deposits.

In summary, however, the disturbance to an orderly biozonal progression has been less dramatic than might have been expected. Some foraminifers, as well as other microfossils (e.g., Calpionellids), undoubtedly have been reworked, however they are rare compared with the bulk of the collected microfossils. The latter certainly have been displaced; nevertheless, their natural vertical arrangement does not seem to have been disturbed to the extent that their chronostratigraphic succession has become unrecognizable.

In this section, stages or substages and their boundaries will be analyzed and the text will be restricted to the chronostratigraphic zoning. Consequently, we have dealt with only a small part of the collected foraminifers. The more important species are shown on five photographic plates.

\section{Lower Cretaceous Series}

\section{The Oldest Level: Upper Hauterivian}

The age of the basal beds was not established utilizing foraminifers; the age determination is based on Hauterivian macrofossils, as determined by Professor O. Renz (this volume). Nevertheless, late Hauterivian is suggested by the planktonic foraminifers, which appear as early as Core 133 . In all probability, the sediment facies would have been suitable for their existence from Core 138 upward. It is generally accepted that planktonics did not appear before late Hauterivian. The rate of sedimentation at the bottom of the hole suggests that somewhat older levels in the Hauterivian may have been reached, but this is not substantiated paleontologically.

Some of the most important species here in the hole appear earlier in the Valanginian ( $\dagger$ ) and frequently continue at least into the Barremian $(*)$. The following species can be mentioned:

*Trocholina infragranulata Noth, 1951 (Plate 1, Figure 19)

†*Trocholina molesta Gorbatchik, 1959 (Plate 1, Figures 8 and 9)

Bigenerina gracilis Antonova, 1964 (Plate 1, Figures 8 and 9)

*Ammobaculites cf. reophacoides Bartenstein, 1952 (Plate 1, Figure 16)

*Marssonella ouachensis Sigal, 1952 (Plate 1, Figure 21)

*Lingulina loryi (Berthelin, 1880) (Plate 1, Figure 17)

Lingulina loryi var. gorringei Maync, 1972 (Plate 1, Figure 18)

$\dagger^{*}$ Lenticulina ouachensis Sigal, 1952 (Plate 1, Figure 22)

$\dagger^{*}$ Lenticulina ouachensis var. multicella Bart., Bettenst., and Bolli, 1957 (Plate 1, Figure 23) 
$\dagger^{*}$ Lenticulina eichenbergi Bartenstein and Brand, 1951 (Plate 1, Figure 20)

$\uparrow$ Marginulina schreiteri (Eichenberg, 1935)

†Conorboides hofkeri (Bartenstein and Brand, 1951).

Other noteworthy species or specific groups are as follows: Spiroplectinata n. sp. 138, Gubkinella graysonensis (Tappan, 1940); the first exemplars of "Discorbis" and Gavelinella, Haplophragmoides cf. grandis (Romanova, 1955); Vidalina bulloides Antonova 1964; various Lagenids which were listed by $\mathrm{H}$. Bartenstein and T. Neagu; and lastly, some representatives of Polymorphinidae.

From the bottom of the hole upward, agglutinated foraminifers are well represented and particularly recall the assemblage described by $\mathrm{H}$. Bartenstein for DSDP Leg 27: Hyperammina sp. p. (H. gaultina ten Dam, 1950 [Plate 1, Figure 3]; $H$. sp. 1 Bartenstein, 1974 [Plate 1, Figure 4]; etc.); Hippocrepina depressa Vasicek, 1947 (Plate 1, Figure 5); Ammodiscus sp. p. (A. infracretaceus Akimetz, 1966, etc.); Glomospira sp. p. (G. gordialis [Jones and Parker, 1860] [Plate 1, Figure 10]; G. charoides [Jones and Parker, 1860] [Plate 1, Figure 12]); Glomospirella sp. p. (G. multivoluta [Romanova, 1955] [Plate 1, Figure 14]); Reophax cf. minutissima Bartenstein and Brand, 1951 (Plate 1, Figure 2); Bigenerina gracilis Antonova, 1964; Spirillina neocomiana Moullade, 1961 (Plate 1, Figure 13); and Haplophragmoides sp. p. However, in the Hauterivian interval, they do not correspond to the "primitive arenaceous," residual (undissolved) abyssal inhabitants, since they participate in the overall benthic association belonging to sediments deposited above the CCD.

\section{Hauterivian/Barremian Boundary}

This boundary cannot be properly traced with the help of foraminifers, and is located (based on ammonites) between Cores 136 and 130 . The boundary has been placed in Core 133 (i.e., Sample 133-5, 64-66 cm), where planktonic foraminifers first appear; actually, Hedbergella sigali Moullade, 1966, appears somewhat earlier, in the uppermost Hauterivian, whereas $H$. tuschepsensis Antonova, 1964, has been described within Barremian and lower Aptian sediments.

\section{Barremian (Cores 133 pars to 128)}

This stage has been effectively characterized with the help of Ammonites and a group of foraminifers. Nevertheless, few of them are confined to this stage (i.e., Discorbis agalarovae Antonova, 1964, and Clavihedbergella eocretacea Neagu, 1975). Many species come from the Hauterivian, some of which continue later into the Aptian ( $\dagger$ ), as indicated below.

$\dagger$ Ammobaculites reophacoides Bartenstein, 1962

†Spirillina neocomiana Moullade, 1961

$\dagger$ Trocholina infragranulata Noth, 1951

Trocholina molesta Gorbatchik, 1959

$\dagger$ Marssonella ouachensis Sigal, 1952

$\dagger$ Lingulina loryi (Berthelin, 1880)

Lingulina loryi var. gorringei Maync, 1972 $\dagger$ Lenticulina ouachensis Sigal, 1952

$\dagger$ Lenticulina ouachensis var. multicella Bart., Bett., and Bolli, 1957

Gubkinella graysonensis (Tappen, 1940) (Plate 1, Figure 29)

Neobulimina inversa Antonova and Gnedina, 1964 (Plate 2, Figure 17)

$\dagger$ Hedbergella sigali Moullade, 1966 (Plate 1, Figures 27 and 28)

Hedbergella tuschepsensis Antonova, 1964 (Plate 1, Figures 25 and 26).

Lastly, the following species begin in this stage and continue into the Aptian:

Lamarckina (?) asteriaformis Kuznetsova and Antonova, 1964 (Plate 2, Figures 7 and 8)

Gavelinella barremiana Bettenstaedt, 1952 (Plate 2, Figures 5 and 6)

Hedbergella aptica (Agalarova, 1951) (Plate 2, Figures 13 and 14)

Hedbergella aff. planispira auct. (Plate 2, Figures 1 and 2)

Hedbergella tardita Antonova, 1969 (Plate 2, Figures 11 and 12).

The planktonic foraminiferal association is far richer than indicated on these lists. They include many small new species belonging to Hedbergella and Globigerinelloides, and some species more-or-less similar to the open forms listed in the Barremian stratotype (Guillaume and Sigal, 1965).

A singularity must be emphasized, which consists of abundant and short-lived (mainly Core 128) Opthalmidiidae (mainly Opthalmidium tricarinatum var. marginatum [Wisniowsky, 1890], which was mentioned by Neagu in the Rumanian lower Neocomian).

A relatively precocious appearance of Gavelinella barremiana must be underlined. This species generally begins approximately in the middle part of the Barremian. However, the distinction from some Discorbis in Hole 398D is not clear-cut. We would be tempted to put the lower/upper Barremian boundary in Core 129, i.e., at the $\mathrm{MCi} 13 / \mathrm{MCi} 14$ boundary (first Hedbergella aptica). This boundary is always difficult to determine, particularly when the guide fossil Conorotalites bartensteini var. aptiensis is missing, as is true at Site 398 (where it appears high in the section), and when the other varieties of the same species are also missing.

The "residual" agglutinated group is still homogeneous, and the same species as before are found here.

\section{Barremian/Aptian Boundary}

This boundary was not satisfactorily located between Cores 128 and 127, since the Bedoulian group of planktonic species begins its main development somewhat higher (Core 122), probably because of sedimentological conditions or poor preservation.

In other respects, Hedbergella similis Longoria, 1974, whose appearance is generally set at the lower limit of the Aptian, co-exists in the hole with Barremian ammonites (see Introduction, this volume). In this case, the scale must be slightly amended, relative to the boundary between Zones MCi 15 and MCi 16 . 
As usual, the boundary is slightly transgressed by some species like Lenticulina ouachensis var. multicella, Epistomina caracolla (Plate 2, Figures 9 and 10), Discorbis agalarovae. The case of Spirillina neocomiana is more questionable, even apart from its synonymy with Vidalina bulloides (Agalarova, 1951) or with the Globospirillina group of Antonova, 1964. The upper limit of the range of this species generally coincides more-or-less with the boundary under discussion, but at Site 398 it is found far higher in the Bedoulian, if we consider its sporadic continuation in the Gargasian and its isolated presence in the middle Albian to be irregular (also evidenced by other accompanying reworked species and turbiditic conditions).

\section{Aptian (Cores 127 to 103 or 100)}

The following group of species suggests an early Aptian (Bedoulian) age, because of either their continuation (as discussed above) or their first appearance:

Hedbergella aptica (Agalarova, 1951)

Hedbergella quadricamerata Antonova, 1964 (Plate 2, Figure 19)

Hedbergella tardita Agalarova, 1964 (Plate 2, Figures 11 and 12)

Hedbergella semi-elongata Longoria, 1974

Hedbergella similis Longoria, 1974 (Plate 2, Figures 15 and 16)

Globigerinelloides (Blowiella) blowi (Bolli, 1959) (Plate 2, Figure 20)

Globigerinelloides duboisi (Chevalier, 1961) (Plate 2, Figure 23)

Globigerinelloides gottisi (Chevalier, 1961) (Plate 2, Figure 21)

Neobulimina egojani Antonova, 1964 (Plate 2, Figure 22)

"Bolivina" kuznetsovae Antonova, 1964 (Plate 3, Figure 2)

The discrepancy we find with the $\mathrm{MCi} 17-\mathrm{MCi} 18$ zonal succession is probably due to sampling or sediment sorting, or to depositional conditions. Alternately, a short stratigraphic break could be present at the base of the Aptian. Other noteworthy species are as follows:

Vidalina bulloides (Agalarova, 1951)

Marssonella subtrochus Bartenstein, 1962

Lenticulina gr. collignoni Espitalié and Sigal, 1963

Lenticulina gr. ambanjabensis id.

Astacolus deilmanni Kęmper, 1963

Epistomina alveata Espitalié and Sigal, 1963 (Plate 2, Figure 18)

"Bolivina aptica" Tajrov, 1961 (Plate 3, Figure 1)

Neobulimina media Antonova, 1964

Hedbergella kugleri (Bolli, 1959)

Hebergella $\mathrm{cf}$. planispira sp. auct.

Conorotalites bartensteini var. aptiensis Bettenstaedt, 1952

and various Lagenidae, Anomalinidae, and Gavelinellidae

The following species come from older intervals and may be considered as not having been reworked, as previously noted:
Lenticulina ouachensis var. multicella Bart., Bettenst. and Bolli, 1957

Epistomina caracolla (Roemer, 1841) (Plate 2, Figures 9 and 10)

Discorbis agalarovae Antonova, 1964

Neobulimina boliviniformis Antonova and Kalugina, 1964

Spirillina neocomiana Moullade, 1961

The following other Neocomian species are normally found in this substage:

Ammobaculites reophacoides Bartenstein, 1952

Marssonella ouachensis Sigal, 1952

Trocholina aptiensis Iovtcheva, 1962 (Plate 2, Figure 27)

Trocholina friburgensis Guillaume and Reichel, 1957

(Plate 2, Figure 26)

Trocholina infragranulata Noth, 1951

Lenticulina ouachensis Sigal, 1952

Gavelinella barremiana Bettenstaedt, 1952

Epistomina laticostata Antonova, 1964

Lamarckina asteriaformis Antonova, 1964

Hedbergella sigali Moullade, 1966

Hebergella tuschepsensis Antonova, 1964

The belated appearance (Core 113) of Globigerinelloides maridalensis (Bolli, 1959) is noteworthy (Plate 3, Figure 8).

The Bedoulian/Gargasian boundary seems to occur between Cores 119 and 118, judging from the upper limit of such species as Hebergella tuschepsensis and $H$. sigali, and the possible existence of two poorly preserved exemplars of Hastigerinella bizonae Chevalier, 1961 (Sample 117-6, 76-78 cm).

The late Aptian substage (Gargasian and theoretically Clansayesian) is greatly enlarged, for it corresponds to the beginning of the high sequential levels which characterize Sub-unit IIc (with "macrosequences") and precedes the "dark shales" series. Thus, we can expect to trace more easily the succession of biozones, given that the required microfossils exist.

The lowest zone, the Cabri zone (MCi 19), was not firmly established for lack of its guide species Schackoina cabri Sigal, 1952. Nevertheless, the following observations enabled recognition of this zone which is localized in Cores 118 to 113 :

last occurrence of Hebergella aptica (Agalarova, 1951)

last occurrence of Hedbergella similis Longoria, 1974 last occurrence of Hedbergella semi-elongata Longoria, 1974

continuation of Hedbergella triangulata Antonova, 1964 (Plate 3, Figure 7)

occurrence of Globigerinelloides escheri (Kaufman, 1865) (Plate 3, Figure 9)

occurrence of Hedbergella $\mathrm{cf}$. kuhryi Longoria, 1974 occurrence of Hedbergella gargasiana Moullade, 1961 (Plate 3, Figures 3 and 4)

The Ferreolensis zone (MCi 20) and Algerianus zone (MCi 21) are no longer characterized by their guide species. They must exist in Cores 112 to 109 pars: 
Globigerinelloides ferreolensis (Moullade, 1961) was belatedly first observed in Core 109 (Plate 3, Figure 12). Moreover, only some less evolute or young forms, perhaps referable to $G$. algerianus Cushman and ten Dam, 1948, were found. Additionally, some exemplars seem to belong to G. macrocamerata Longoria, 1974, which is restricted to the last zone mentioned.

The Trochoidea zone (MCi 22) is well characterized; Hedbergella trochoidea (Gandolfi, 1942) was found from the middle of Core 109 upward (Plate 3, Figures 10 and 11). Forerunners, with a large shell, coarsely perforated and pustulose, are present below Core 109. They can be related either to $H$. hispaniae Longoria, 1974 , or to "pre-trochoidea" forms, in accordance with observations made in northern Africa and recorded by M. Moullade in southeastern France.

Ticinella bejaouaensis Sigal, 1966, was not found. Consequently, the Bejaouaensis zone (MCi 23) cannot be defined. Nevertheless, some forms belonging to the group of $H$. trochoidea occur as early as Core 107, with more numerous chambers, a depressed spire, and large umbilical cavity (Plate 3, Figures 14 and 15). Only the indispensable supplementary apertures are missing, in accordance with observations made in northern Africa and southeastern France by the same authors. Such variants probably belong to Globigerinids, described as Praeglobotruncana rohri by Bolli, 1959. The coexistence of such forms with Nedbergella trochoidea, Planomalina cheniourensis Sigal, 1952 (Plate 3, Figure 13), and Globigerinelloides barri (Bolli, Loeblich, and Tappan, 1957) (Plate 3, Figure 20) suggests that we have not yet reached the Clansayesian substage. Since the samples come from the large slump in Cores 105 and 104 , we assume either that their occurrence was contemporaneous with the slumping or that the bulk of the material was displaced soon after its original deposition. We should point out that true reworked material occurs in the cores.

Besides the preceding guide fossils, the upper Aptian deposits yield a characteristic assemblage, composed of benthic forms, such as:

numerous species of Lagenidae, Gavelinella, Gyroidina, well known since Reuss (Hils and Gault)

Spiroplectinata group of davidi Moullade, 1961

Saracenaria spinosa Eichenberg, 1935

Eponides morani Tappan, 1957

Eurycheilostoma sp. p. (close to robinsonae and grandstandensis described by Tappan, 1957, from Alaska) (Plate 3, Figures 18 and 19)

"Bolivina" kuznetsovae Antonova, 1964 (Plate 3, Figure 2)

"Bolivina" textilarioides (Reuss, 1863)

Conorotalites brotzeni var. rumanus Neagu, 1965

and some representatives of the family Pleurostomellidae (Pleurostomella obtusa Berthelin, 1880 as early as Trochoidea zone, Ellipsodimorphina sp.). Affinities with the Canadian realm also are noticeable.

Residual agglutinated forms are especially prominent from Core 119 upward, since they may henceforth compose the entire foraminiferal content of the samples. The assemblage is not fundamentally different: the same Hyperammina, Hippocrepina, Glomospira, and Ammodiscus as below, as well as Ammodiscus cretaceus (Reuss, 1845), Mjatljukella gaultina (Berthelin, 1880), and Rothina silesica Hanzlikova, 1966; for a relatively short time-rock interval, Verneuilinoides group of subfiliformis Bartenstein, 1952 (Plate 3, Figure 6) and Bigenerina variabilis (Vasicek, 1947) (Plate 3, Figure 5) were found.

Reworked species are undeniable, either because they are now found too far from their usual time range, or because redeposition is indicated by the nature of the sediment itself (turbiditic lower sequential intervals, debris flows, Calpionellids-bearing pebbles). These forms include Pseudonodosaria group of mutabilis (Reuss, 1863), P. group of humilis (Roemer, 1841), some small Hedbergellas (cf. sigali, cf. semi-elongata), Dorothia ouachensis, Lenticulina ouachensis var. multicella, and the more frequently observed and previously discussed Spirillina neocomiana. The last species is encountered mainly in Cores $118,117,112$, 108, 105, 104, and 103, as indicated in Table 1.

Aptian/Albian Boundary, With a Possible Stratigraphic Break

From the foregoing, it follows that the uppermost part of the Aptian has not been paleontologically characterized. Between the Trochoidea zone and the next ammonites of the Mamillatum zone (which is not the lowest one in the Albian), the sediment sequence appears to be thin, especially if we consider the sedimentation rate at that time. If we assume that the age of the large flow in Cores 105 and 104 is approximately determined by the youngest microfossils found, this boundary occurs somewhere in Cores 103 to 100 . We could not attain any greater precision with foraminiferal determinations, since planktonics are missing and benthics are sporadic, uncommon, and generally belong to wide-ranging species without well-defined limits. One of the guide-species frequently utilized for the Aptian/ Albian boundary (Pleurostomella subnodosa Reuss, 1860 ) cannot be used for this site because its first occurrence is very late, while $P$. obtusa (sometimes considered as its macrospheric counterpart) appears in the hole as early as the Trochoidea zone.

The thinness of the sediments, which should encompass the Clansayesian substage and basal Albian (i.e., MCi 23) and perhaps also part of the Trochoidea zone (part of $\mathrm{MCi} 22$ ), suggests a stratigraphic break. The break might be related to general diastrophic events which resulted in the large allochthonous slump in Cores 105 and 104, and in the definitive development of the "dark shales." For greater convenience and convention, the boundary is placed between Cores 104 and 103 .

\section{Albian (Cores 103 or 100 to 58)}

The thick series dated as Albian (including Vraconian) yielded a characteristic assemblage of foraminifers. Planktonics belong to the common forms which are usually found in the Mesogean realm, although their specific composition and abundance vary greatly. Benthics show a great similarity to the Mesogean microfauna, either Mediterranean (especially 
from northern Africa and southeastern France or Spain, from where they have been well described) or from other areas (we find some species described or listed in California or India). Nevertheless, some affinity exists with more northern realms, e.g., with the classic Gault formations as concerns Lagenidae, or with Alaskan areas as concerns some other species or genera. During the Albian, many benthic foraminifers were distributed in a wide geographic belt, including various Lagenidae, many species of Gavelinellidae, Pleurostomellidae, Verneuilinidae, especially Pseudoclavulina gaultina var. carinata Neagu, 1962 (Plate 4, Figure 7), and Osangularia utaturensis (Sastry and Sastri, 1966) (syn. O. california Dailey, 1970) (Plate 3, Figures 21 and 22) or O. insigna Dailey, 1970 (Sample 59-6, 11-13 cm). These are well represented in Hole 398D.

These benthic assemblages were transferred from the outer shelf or the upper-middle slope toward deeper areas below the CCD. A detailed study of successive samples reveals multiple alternations of very different assemblages which represent either "autochthonous" associations of residual microfossils or mixed assemblages, depending on the amount and degree of preservation of the redeposited calcareous material.

Thus, at least during a large part of the stage, some difficulties were encountered in establishing the zonal stratigraphy, because of the impoverishment or the sporadic occurrence of the microfauna. Only from Core 70 or 69 upward (i.e., approximately at the base of the upper Albian) did favorable sedimentological conditions prevail. Rich or sometimes exuberant benthic and planktonic associations allowed a detailed stratigraphic zonation to be established in this interval.

Chronologically, we cannot assert that the first occurrence of Hedbergella planispira (Tappan, 1940) in Sample 94-4, 30-32 cm (Plate 3, Figures 23 and 24) determines the $\mathrm{MCi} 23 / \mathrm{MCi} 24$ boundary (i.e., the middle part of the lower Albian); the microfauna are poor and sporadic at this level. The same unreliability prevails for the MCi $24 / \mathrm{MCi} 25$ boundary (i.e., near the base of the middle Albian), according to the presence of species like Hedbergella rischi Moullade, 1973, in Sample $82-1,51-53 \mathrm{~cm}$ or Ticinella primula Luterbacher, 1963, in Sample 86-2, 38-40 cm (Plate 4, Figures 5 and 6). For the lower/middle Albian boundary, we accept that it occurs in Cores 92 to 91 , according to the ammonites.

The position of the middle/upper Albian boundary (or $\mathrm{MCi} 25 / \mathrm{MCi} 26$ ) is placed at the first occurrence of Biticinella breggiensis (Gandolfi, 1942) in Sample 69-2, $89-91 \mathrm{~cm}$ (Plate 4, Figure 11), and just before the first occurrence of Ticinella praeticinensis Sigal, 1966, (Plate 1, Figures 14 and 15). The first occurrence of Rotalipora ticinensis (Gandolfi, 1942) in Sample 65-1, 135-137 cm (Plate 4, Figures 19 and 20) approximately defines the middle part of the upper Albian (Dipoloceras cristatum Zone), just before the last Rotalipora praeticinensis in Sample 65-1, 58-60 cm.
The MCi 26/MCi 27 boundary corresponds to the last occurrence of Biticinella breggiensis in Sample 60-3, $13-15 \mathrm{~cm}$; it is preceded as usual by the first occurrences of Rotalipora balernaensis Gandolfi, 1957 in Sample 62-2, 148-150 cm (Plate 4, Figures 22 and 23) and Planomalina buxtorfi (Gandolfi, 1942) in Sample 61-1, $120-122 \mathrm{~cm}$ (Plate 4, Figures 27 and 28), whereas Rotalipora apenninica (Renz, 1936) occurs somewhat belated in Sample 60-1, 6-8 cm (Plate 4, Figures 29 and 30).

The upper Albian/Vraconian boundary corresponds to the first occurrence of the above-mentioned species $R$. balernaensis and $P$. buxtorfi, or more precisely at the end of the evolution lineage Globigerinelloides caseyi (Bolli, Loeblich, and Tappan, 1957) (Plate 4, Figure 21), Globigerinelloides praebuxtorfi (Wonders, 1975) (Plate 4, Figure 26) leading to $P$. buxtorfi, which is well documented at Site 398.

The upper limit of Rotalipora ticinensis in Sample 59-3, 103-105 $\mathrm{cm}$ approximately defines the middle part of the Vraconnian (or the boundary between the Mortoniceras perinflatium and Turrilites hugardianus zones).

Lastly, the upper limit of the Albian can be located at the base of Core 57, with the first occurrence of Rotalipora globotruncanoides Sigal, 1948 (Plate 4, Figures 8 and 9) and Thalmanninella brotzeni Sigal, 1948 (Plate 4, Figures 10 and 11), and with the diversification of the Schackoina cenomana group (Plate 4, Figures 2 through 7) (S. cenomana [Schacko, 1897]; $S$. cenomana var. bicornis Reichel, 1948; S. gandolfii id.; $S$. moliniensis id.; $S$. pentagonalis id.; and $S$. cf. primitiva Tappan, 1940). Incidentally, we observed a short-living manifestation of $S$. cf. cenomana s. str. (Plate 4, Figure 18) in Sample 65-5, 135-137 cm, approximately in the middle part of the late Albian s. str. (which is earlier than usual). It was found in a few samples, where it occurs together with a very enigmatic form which seems to correspond to an uncoiled Hedbergella (see Plate 5, Figures 19 to 25), and probably belongs to the planispira group.

Late Albian and Vraconian planktonics are diversified and we found almost all the guide fossils of stratigraphic significance. We noticed that Ticinella roberti is nearly absent; Ticinella raynaudi Sigal, 1966, and $T$. primula are uncommon; only one exemplar of Favusella washitensis (Carsey, 1926) was found. The small-sized planktonics are very numerous and diversified: Hedbergella planispira (Tappan, 1940), $H$. globigerinelloides (Subbotina, 1949) (Plate 4, Figures 3 and 4), Globigerinelloides ultramicra and G. modesta (Bolli, 1959) (Plate 3, Figures 26 and 27) constitute only a small part of the total amount. There are probably many new species (few chambered, or with digitate chambers) or variants (e.g., a subsymmetrical form of G. modesta).

The bulk of the residual agglutinated forms remains the same, with some exceptions such as the extinction of 
Verneuilinoides gr. subfiliformis and Bigenerina variabilis very early in the stage (Core 99) and the extinction of Rothina silesica (Core 71).

\section{Cenomanian (Cores 57-56 pars)}

The layers which can be assigned to the Cenomanian are thin (Core 57 and Samples 56, CC to 56-2, 23-24 $\mathrm{cm}$ ), although the uppermost beds (Samples 56-3, 3-5 $\mathrm{cm}$ to $56-2,23-24 \mathrm{~cm}$ ) cannot be dated with the help of foraminifers which are missing there. The upper limit has been placed at a lithologic change (texture, color).

The Cenomanian is probably incomplete. The first Cenomanian levels, up to the base of Core 56, seem to pursue the Vraconian without change, with the same lithology and microfauna (the persistence of Planomalina buxtorfi is noteworthy). A subdivision in the lower Cenomanian can be made with the first occurrence of Rotalipora montsalvensis Mornod, 1950 in Sample 56-6, 105-107 cm (Plate 5, Figures 13 and 14). This delimitation involves a thin lower part of the lower Cenomanian.

Similarly, a short interval separates this form from the first exemplars of Rotalipora cushmani (Morrow, 1934) in Sample 56-3, 45-47 cm (Plate 5, Figures 15 and 16 ) and $R$. reicheli Mornod, 1950, in Sample 56-3, 76-77 $\mathrm{cm}$ (Plate 5, Figures 17 and 18 ) which probably correspond to a young level in the middle Cenomanian.

It seems that Core 56 belongs to a renewed sequential regime and, consequently, that the microfauna may have been displaced if not reworked. Corrosion and probable solution traces are perceptible, especially from Section 56-5 upward; microfaunal assemblages do not look like those in the underlying beds (less homogeneous, impoverished?); clasticity has increased since Core 59. The middle Cenomanian assemblages come from thin calcareous intercalations, with debris and small rounded pebbles, which are very different from the surrounding, more argillaceous sediment which has few or no microfossils upward from Sample 56-2, 119 $\mathrm{cm}$.

The shortness of the Cenomanian series could result, of course, from condensed sedimentation. However it seems that major perturbations with reworked material and perhaps stratigraphic breaks were important during this long time interval, which is dated only twice by renewed microfaunal assemblages.

Middle Cenomanian deposits are overlain by strata which seemingly belong to the early Senonian. This large hiatus at the top of Core 56 is probably genetically related to well-known worldwide events which particularly have been investigated in the North Atlantic (Bartlett and Smith, 1971; Hart and Tarling, 1974; Hart, 1976).

\section{Upper Cretaceous Series}

Several units can be distinguished in the sedimentary column above the stratigraphic break in Core 56 .

\section{Unit 1: From Samples 56-2, $19 \mathrm{~cm}$ to 50-6, $15-17 \mathrm{~cm}$}

Its upper limit corresponds to the first occurrence of calcareous benthic and planktonic foraminifers (which are lacking below, with the exception of some reworked exemplars). This first unit is paleontologically characterized by an agglutinated assemblage.

This assemblage seems to be homogeneous from bottom to top; the more important species or genera are as follows:

Praecystammina cf. globigeriniformis Krasheninnikov, 1973

Ammodiscus cf. rotalarius Loeblich and Tappan, 1949 or cretaceus (Reuss, 1845) in Krashen, 1974.

Hyperammina? sp.

cf. Bathysiphon nodosariaeformis Subbotina, 1950

Glomospira corona Cushman and Jarvis, 1928

Glomospira tortuosa Eicher, 1960

Glomospirella (Mjatjukella) gaultina (Berthelin, 1880)

Hormosina ovulum (Grzybowski, 1901)

Reophax sp. cf. R. bohemicum (Perner, 1897)

Trochammina cf. böhmi Franke, 1928

Trochammina cf. gyroidinaeformis var. altiformis Cushman and Renz, 1946

Paratrochamminoides corpulentus Krasheninnikov, 1973

Paratrochamminoides intricatus Krasheninnikov, 1973

Haplophragmoides molestus Krasheninnikov, 1973

Haplophragmoides aff. herbichi Neagu, 1968 or linki Nauss, 1947

Haplophragmoides decussatus Krasheninnikov, 1973

Ammobaculites sp.

Verneuilinoides $\mathrm{cf}$. perplexa (Loeblich, 1946)

Uvigerinammina sp. $\mathrm{p}$.

Spiroplectammina cf. steinekei Finlay, 1939

Recurvoides cf. pseudosymmetricus Krasheninnikov, 1974

Such an assemblage strongly suggests that it is "residual" and represents the benthic part which escaped dissolution beneath the CCD. Many of its components have no stratigraphic value and are encountered in the Upper Cretaceous and the lower Eocene. Nevertheless, some species are important, i.e., Praecystammina $\mathrm{cf}$. globigeriniformis, Recurvoides $\mathrm{cf}$. pseudosymmetricus, Haplophragmoides molestus, $H$. decussatus, Trochammina cf. böhmi?, Paratrochamminoides intricatus, and $P$. corpulentus. If we compare this assemblage with recent studies by V. A. Krasheninnikov on material from Legs 20 and 27, we can propose a Senonian age, probably Santonian or Campanian.

This determination is significant because it means that a large stratigraphic break extends between the middle Cenomanian and "middle" Senonian. This must be considered as a working hypothesis, because we must not forget that agglutinated foraminifers are facieslinked forms.

In this interval, a few samples yield some calcareous forms which are poorly preserved and sometimes have solution marks. They have probably been displaced and come from older sediments, mainly from the Cenomanian. The following species were found:

Gavelinella sp. p. (Samples 54-2, 104-106 cm, and $54-1,99-101 \mathrm{~cm}$ ) 
Gyroidina mauretanica Carbonnier, 1952 (Samples $51-2,66-68 \mathrm{~cm})$

Hedbergella cf. modesta (Bolli, 1959) (Sample 51-2, $66-68 \mathrm{~cm}$ )

Globigerinelloides sp. (Sample 52, CC)

Rotalipora apenninica (Renz, 1936) (Samples 53-2, $141-143 \mathrm{~cm}$, and $51-3,99-101 \mathrm{~cm})$

Globotruncana imbricata Mornod, 1950 (Sample $53-2,141-143 \mathrm{~cm})$

Some agglutinated forms are perhaps reworked from late Cenomanian or Turonian deposits, e.g., Haplophragmoides cf. herbichi Neagu, 1968 (in Samples 52, CC; $52-4,143-145 \mathrm{~cm}$; and 52-4, 39-41 cm).

The micropaleontological monotony in the specific composition of the agglutinated residual assemblage is compensated for by some varying features within this interval. Finally, the agglutinated assemblage itself is quantitatively variable, i.e., absent or very rare at the base (Cores 56 and 55), becoming common later (Core 54 ) and progressively abundant (Cores 53 and 52), then suddenly disappearing or again becoming very rare (Cores 51 and 50 pars).

Similarly, the reaction of sediment fragments to $\mathrm{HC} 1$ as seen under the microscope changes in the course of Core 52 , from dominantly negative below to positive above; then it remains positive upward, until the calcareous or chalky sediments of the upper Senonian. The structure of the sediment also seems to be modified (frequency and length of the rhythmic sequences, color, texture). Within this stratigraphic interval, another break concerns the radiolarians which disappear from Core 55 or 54 upward.

All these features at Site 398 probably reflect, on our microscopic scale, the existence of more widespread geologic phenomena.

Unit 2: From Samples 50-6, 15-17 cm to 41-5, 140-142 cm

Henceforth, calcareous species of foraminifers (benthic as well as planktonic) are present and numerous. The first pertinent samples (especially Samples 50-6, $15-17 \mathrm{~cm}$ to $50-2,16-18 \mathrm{~cm}$ ) are chronostratigraphically important. Diagnostic species are as follows (besides numerous forms belonging to Pleurostomella, Discorbis, Epistominella, Bulimina, and Gümbelina):

Spiroplectammina gr. dentata (Alth, 1850)

Buliminella pusilla (Brotzen, 1936)

Aragonia gr. paynei (Morrow, 1934) - ouezzanensis (Rey, 1955)

Globotruncana linnei (d'Orbigny, 1839)

Globotruncana cf. cachensis Douglas, 1966

Globotruncana fornicata Plummer, 1931

Globotruncana stuartiformis Dalbiez, 1955

This sample therefore can be placed in the middle Senonian; it belongs at least to the uppermost Santonian. This oldest age is corroborated by Sample 50-2, $16-18 \mathrm{~cm}$, whose maximum age is lowermost Campanian, based on the presence of Globotruncana concavata (Brotzen, 1936).

From Sample 50-6, 15-17 cm to the top of Core 45, the foraminiferal assemblage vary slightly; benthics are generally numerous, more so than planktonic forms. Solution marks are perceptible, particularly on the latter. Among the more important species are the following:

Spiroplectammina gr. dentata (Alth, 1850)

Spiroplectammina regularis Hofker, 1957

Eouvigerina aculeata (Ehrenberg, 1854)

Pseudouvigerina plummerae Cushman, 1927

Bolivinita eleyi Cushman, 1927

Bolivinita $\mathrm{cf}$. selmensis Cushman, 1933

Bulimina kickapooensis Cole, 1938

Buliminella pusilla (Brotzen, 1936)

Reussella szajnochae var. praecursor de Klasz and Knipscheer, 1955

Reussella szajnochae (Grzybowski, 1896)

Bolivina kalinini Vasilenko and Mjatljuk, 1947

Aragonia ouezzanensis (Rey, 1955)

Bolivinoides decorata (Jones, 1886)

Bolivinoides miliaris Hiltermann and Koch, 1950, var.

Bolivinoides pustulata Reiss, 1954

Neoconorbina supracretacea (Schijfsma, 1946)

Gavelinella whitei (Martin, 1954)

Stensiöina pommerana Brotzen, 1936

Nuttallinella florealis (White, 1928)

Nuttallinella texana (Cushman, 1938)

Nuttallinella spinea (Cushman, 1938)

Osangularia cordieriana (d'Orbigny, 1840)

Osangularia velascoensis (Cushman, 1925)

Conorotalites subconica (Morrow, 1934)

Pullenia jarvisi Cushman, 1936

Gümbelina costulata Cushman, 1938

Globotruncana arca (Cushman, 1926)

Globotruncana cf. arcaformis Maslakova, 1974

Globotruncana cachensis Douglas, 1966

Globotruncana caliciformis (J. de Lappar, 1918)

Globotruncana convexa Sandidge, 1932

Globotruncana elevata (Brotzen, 1936)

Globotruncana fornicata Plummer, 1931

Globotruncana linnei (d'Orbigny, 1839)

Globotruncana rugosa (Marie, 1941)

Globotruncana stuartiformis Dalbiez, 1955

Globotruncana tricarinata (Quereau, 1893)

Hedbergella $\mathrm{cf}$. loetterlei (Nauss, 1947)

Globigerinelloides ehrenbergi (Barr, 1962)

Planomalina rowei Barr, 1962

Planomalina yaucoensis Pessagno, 1960

The age of this assemblage is Campanian. The boundary with the Santonian is characterized by the coexistence, in two close samples, of Globotruncana concavata and $G$. stuartiformis. The top of the stage is not well documented because of the absence of $G$. calcarata (Cushman, 1927). Nevertheless, the presence of some exemplars similar to Bolivinoides draco and the first occurrence of Nuttallinella spinea suggest that Core 47 is still very upper Campanian.

Some previously listed agglutinated species persist in the Campanian (i.e., Glomospira corona, G. tortuosa, Glomospirella sp., Recurvoides cf. subglobosus, and Ammodiscus cf. cretaceus). 
At the top of Core 45, we observed some Globotruncana very close to $G$. caliciformis, as well as probably G. stuarti (J. de Lappar., 1918). Core 44 provides the first occurrence of G. citae Bolli, 1951; Bolivina incrassata Reuss, 1851; Osangularia lens Brotzen, 1940; and advanced forms of Reussella szajnochae. These sediments were deposited during the Maestrichtian.

From Core 44 to Sample 41-6, 38-40 cm, the following species belong to a Maestrichtian assemblage:

Ammodiscus sp.p

Glomospira corona Cushman and Jarvis, 1928

Glomospira tortuosa Eicher, 1960

Haplophragmoides spp

Trochammina sp.

Pseudoclavulina clarata (Cushman, 1926)

Arenobulimina obliqua (d'Orbigny, 1840)

Arenobulimina cytherea Marie, 1941

Aragonia ouezzanensis (Rey, 1955)

Bulimina kickapooensis Cole, 1938

Reussella szajnochae (Grzybowski, 1896)

Bolivina incrassata Reuss, 1851

Gavelinella whitei (Martin, 1954)

Osangularia lens Brotzen, 1940

Nuttallinella spinea Cushman, 1938

Globotruncana arca (Cushman, 1927)

Globotruncana caliciformis (J. de Lappar., 1918)

Globotruncana citae Bolli, 1951

Globotruncana contusa (Cushman, 1926)

Globotruncana falsostuarti Sigal, 1952

Globotruncana fornicata Plummer, 1931

Globotruncana fundiconulosa Subbotina, 1953

Globotruncana stuarti (J. de Lappar., 1918)

Globotruncana stuartiformis Dalbiez, 1955

Globotruncana tricarinata (Quereau, 1893)

Planomalina yaucoensis Pessagno, 1960

In Samples 43-3, 17-19 cm; 43-2, 133-136 cm; and $43-1,31-33 \mathrm{~cm}$, the uppermost Maestrichtian is characterized by the following newly introduced species:

Gümbelina costulata Cushman, 1938

Ventilabrella glabrata (Cushman, 1938)

Pseudotextularia elegans (Rzehak, 1891)

Racemigümbelina fructicosa (Egger, 1899)

Reussella szajnochae (Grzybowski, 1896) var.

Globotruncana mayaroensis Bolli, 1951

Globigerinella messinae Brönnimann, 1952

Globigerinella messinae var. subcarinata Brönnimann, 1952

Noteworthy is the abundance here of Heterohelicidae, which in previous cores were sporadic or absent.

From Sample 43-1, 31-33 cm upward, the stratigraphic interpretation is difficult. Between Samples $43-2,74-76 \mathrm{~cm}$ and $41-6,38-40 \mathrm{~cm}$, the main Maestrichtian species are still present (some persist into the lowermost Eocene), but they are accompanied by small Globigerinids, some of which are similar if not identical to the so-called Eoglobigerina. The last Globotruncana, Osangularia lens, and Nuttallinella spinea were observed in Sample 41-6, 38-40 cm.

Up to Sample 41-2, 33-35 cm, the same Globigerinid association continues, whereas some Cretaceous species are still encountered as impoverished and sporadic as- semblages, with the exception of some samples from Section 41-2 which yield abundant forms (particularly the late Maestrichtian Heterohelicidae). The first occurrence of Chilogümbelina occurs in Sample 41-5, 52-54 $\mathrm{cm}$.

In summary, the Maestrichtian stage ends with Sample $41-6,38-40 \mathrm{~cm}$, giving way to the first Danian level with reworked Maestrichtian fauna. The latter are particularly present in Section 41-2, especially between Samples 41-2, 49-51 cm and 41-2, 33-35 cm. It should be emphasized that these layers are intensely disturbed and separate two series of different textures and colors. They were interpreted onboard ship (when drilling, i.e., downward) as representing the Tertiary/Cretaceous boundary because of the sudden appearance (downward) of Maestrichtian assemblages.

These layers with very small Globigerinids correspond to our genuine "small-Globigerina zone." They are followed (from Sample 41-2, 34-36 cm upward) by a second Danian level with a multitude of somewhat larger "small Globigerinids," typical forms of the Eugubina zone. The last sample examined (Sample 41-1, $132-134 \mathrm{~cm}$ ) still belongs to this zone.

\section{ECOSTRATIGRAPHY OF LOWER CRETACEOUS FORMATIONS}

This section introduces the relationships between faunal assemblages and the sediments containing them, for the purposes of determining the general trends in their evolution and perhaps reconstructing the sedimentary milieus.

The following ecostratigraphic interpretation has been based mainly on a distinction between transportedredeposited and autochthonous-residual foraminiferal assemblages. Other criteria were likewise involved, such as specific composition, lithologic nature, and sedimentary components, as well as plant content and other associated organisms and organites.

The transported-redeposited assemblages comprise benthic species with calcareous (and agglutinated) shells and are interpreted as originally having been deposited on shelf or slope areas. Sometimes evidence of predation is present. They were then buried in such a condition (milieu, terrigenous supply, speed of accumulation) that the shells have been at least partly preserved, even when deposition took place beneath the CCD (Arrhenius, 1963).

Transported assemblages are generally a composite group of species which lived in different areas (e.g., see Pujos-Lamy, 1973). This will be more thoroughly examined later, along with the paleontological study of the benthic species. The planktonic forms must be considered separately since they are essentially oceanic and, consequently, do not have the same history when found together with benthic ones.

The autochthonous-residual assemblages concern species with non-calcareous (i.e., agglutinated) shells ("deep-water Rhabdammina-fauna" of Brouwer, 1965; "Astrorhizidae-Ammodiscidae taxocoenosis of oceanic type" of Saidova, 1965). Schematically, these assemblages have long been considered (Rzehak, 1887) as 
thriving in deep and relatively cold water (Pokorny, 1960; Saidova, 1965a, b; Brouwer, 1965; Hiltermann, 1968). Nevertheless, this interpretation has not been unanimously accepted (Stainforth, 1952; Pflaumann, 1967). Such assemblages are now generally considered to be the result of two main processes. First is a relative enrichment, such as an adaptative response of specialized "microaerophile" living associations, coupled with the lack of competition due to a severe environment for calcareous species (Le Calvez, 1956). Secondly is a residual assemblage (niche diversification, selective preservation) through diagenetic dissolution ensuing from a reducing environment, which especially occurs below the CCD.

Appropriate studies of outcropping flysch series have enabled us to understand how such specific observations made in an isolated hole can be applied to regional fossil-life conditions and paleogeographic settings (Ksiazkiewicz, 1961; Brouwer, 1965; Hiltermann, 1968, 1975; Hesse, 1975, 1975; Hesse and Butt, 1976; Sliter, 1975; Van Stuijvenberg, Morel, and du Chene, 1976; among the recent literature).

The estimation of the depth of the CCD has resulted in a prolific literature on two subjects. First is the plotting of crestal depth versus age (or its log) curve, which facilitates constructing the approximately depth of deposition (e.g., see Berger, 1972; Berger and Winterer, 1974; Veevers, 1977). Second is the search for specific factors which could have either disturbed this global environmental evolution or developed local conditions. Thus, in the case of Hole 398D, the required depth for carbonate solution could have occurred shallower because of the vast influx of organic matter-rich sediments delivered from either terrigenous sources, or high phytoplankton or zooplankton surface productivity.

In addition to foraminifers, other organisms are present. Radiolarians are particularly frequent, abundant, and diversified. Ostracodes are poorly and sporadically represented (around 60 exemplars were found). Lastly, ammonites (see Renz, this volume) were encountered at different levels, sometimes abundantly. They are noteworthy as to their preservation (nacreous colored shells); this fact, considering the nature of the enclosing sediment (carbonate-depleted clay or dark shales), remains unexplained. A protective effect of the conchioline layers in the textural pattern of the shell might be an avenue of future research work, as was suggested by Mme. G. Termier and as it is presently in progress by Prof. Ch. Grégoire.

Other organic debris are fairly abundant (aptychus, inoceramus) or rare (belemnites, rhyncholites), to which varying amounts of shell fragments must be added (gastropods, pelecypods, echinoids). The washed residues are frequently rich in debris or fish teeth, together with various spicules (mainly sponges, also gorgonids, ascidids); their study by a specialist is desirable.

Analysis of these data enabled successive diagrams of ecostratigraphic units (November 1976, December 1976, March 1977) to be drawn. They satisfactorily coincide with other lithological and sedimentological subdivisions which have been proposed.

The data which are available for such ecostratigraphic analysis are shown on the detailed log of Chart 1A (at the back of this volume), sample by sample, as they were observed in the 63 -micron sieved residues. These data enabled us to develop a sedimentary history.

In this way, several cored interval (Units I to V, with sub-units) were progressively delineated to trace the evolutionary stages of the sedimentary basin at the drill site. In the following pages, these intervals will be described, first with the help of a comparative analysis of the data, to determine some basic categories, either micropaleontologically (assemblages) or lithologically (lithoterms). They will then be described by trying to discern the correlations which could exist between the assemblages and the elementary sequential intervals. Figures 2 through 6 provide an illustration and a definition of the lithoterms for each unit. Additionally, Tables 3 through 11 correlate assemblage frequencies with each lithoterm in the different cores.

The detailed log (Chart 1A) visually depicts some important features, including the following:

1) The location of the large slump in Cores 105 and 104 in the empty space which occurs in the AP (Column $\mathrm{C}$ and left side of Column E, Chart 1A) and, conversely, the "populating"' with calcareous species (in Column D and right side of Column E).

2) The relationship of Core 103 to the slump in Cores 104 and 105, and not to the overlying "dark shales" (as can be seen in Column B, Chart 1A), although this core already belongs to the later facies lithologically (Column $\mathrm{J}$ for pyrite) and partially biologically (Column $\mathrm{H}$ for radiolarians and plant debris, and Column B for AP).

3) Conversely, the forewarning of the giant slump (Cores 104 and 105) as early as Core 110, is exemplified by frequent "peaks" on curves related to $\beta$ or $\pi$ (Column B), without any synchronism with similar features concerning AP (same column), as can be expected because these parameters define a calcareous supply in an "autochthonous" residual community.

4) Such a synchronism is, on the contrary (Column B) between Cores 138 and 131, when the distinction between $\beta$ and AP is no longer or not yet valid in the midst of a unique association which was deposited above the CCD.

5) An "intermediary" stage (Cores 130 to 121) between these extreme sedimentary regimes. It is individualized by the obliteration of the residual AP in favor of $\beta$ and $\pi$.

6) Lastly, the growing clasticity (Column J) in the upper cores.

This study is an example of the difficulty experienced when abundant data is available and when we want to coordinate them into conventional, but perhaps too simplistic schemes. The data themselves are not without some limitations. For instance, there is the already mentioned distinction between $\beta$ and residual AP, depending on the position of the CCD in relation to the ocean 
floor. Like a feed-back effect, the $\beta / A P$ distinction serves to determine the depth of the CCD which, in turn, limits the validity of this distinction. Another limiting factor is the validity of extrapolating of dissolution criteria back into the Early Cretaceous, as these criteria are based on Recent or late Tertiary populations (Sliter, 1975; Sliter et al., 1975; Thunell, 1976; Sliter, 1974).

Such limitations are of less concern when they involve the statistical utilization of data in helping to define the sedimentary evolution. Thus, we took numerous samples. However, the large number of samples also causes a problem, for we rapidly reach the level where the data are so numerous that we cannot succeed in incorporating them in simple schemes. The clearest example is in deciphering whether the drill site was above or below the CCD when the seemingly pelagic sediments of Unit V were deposited.

\section{Unit I: From Cores 138 to 131}

The first unit of lithologic formations corresponds to "marly-calcareous" alternating series, resulting from a repetitive or rhythmic succession of compact massive calcareous and soft laminated marly layers with a low sedimentation rate ( 7 to $8 \mathrm{~m} / \mathrm{m}$.y.). Each pair simulates a graded sequence whose final interval should be formed by a lime facies with calcareous nannofossils and radiolarians. The other beds are composed of fine laminae which, if they are sufficiently closely samples, yield predominantly varying organic or mineral comnents, depending on the kind of selective enrichment they underwent during re-depositional processes.

Note that $A / \beta$ (and $A / \beta^{\prime}$ after planktonics have appeared in Core 133) are the only assemblages to be represented and that, conversely, R/AP s. str. cannot exist as a consequence of deposition shallower than the CCD.

The lithological sequence we refer to involves four lithoterms (Figure 2). The uppermost one (No. 5) forms the skeleton of Cores 138 to 131; the lowermost one (No. 3 ) is relatively poorly represented; Nos. 1 and 2 are the most common. We attempted to determine the originating lithologic term for laminated sediment; this is specified by an arrow above the Arabic number in Chart 1A.

\section{Organogenic Components}

$\alpha$ Microfauna: As mentioned above, only $\mathrm{A} / \beta$ from the beginning (and later $A / \beta^{\prime}$ ) can be present; in the same way, $\mathrm{A} / \mathrm{Az}$ (and later $\mathrm{A} / \mathrm{P}$ ) represent impoverished assemblages.

Benthos: Fairly abundant, often poor, and rarely very abundant; $\beta$ is statistically more abundant in laminae having originated from Lithoterms 2 or 3 . Lagenidae and agglutinated species essentially, from the slope or external shelf; some of the agglutinated foraminifers are the ones which will later form the residual assemblages R/AP underneath the CCD.
Plankton: Generally poor; numerous samples are devoid of $\pi$ (whence a large amount of $\mathrm{A} / \beta^{\prime}$ and $\mathrm{A} / \mathrm{Az}$ ).

Radiolarians: Variable quantitatively, more frequently abundant in the lower cores; simple, globular, ellipsoidal, or conical forms only. They are mainly recrystallized.

$\beta$ Macrofauna: Shell fragments are frequent and varied (gastropods, pelecypods, echinids, ammonites), particularly in the lower cores, but never very abundant in the other cores. Aptychus and inoceramus are especially noteworthy. Debris was encountered only in Lithoterms 2 and 3. Fish debris are frequent, sometimes abundant. Spicules are sporadic and rare.

$\gamma$ Plant debris: Frequent, but moderately represented, increasing upwards.

\section{Inorganic Components}

Clasticity: Weak, except some samples at the top where abundant quartz and mica are related to Lithoterm 3. Noteworthy is the abundance of both mica and plant debris in the same sample, a feature frequently observed later.

Pyrite: Frequent, sometimes abundant, decreasing upwards.

Glauconite: Frequent in the upper part and related to $\mathrm{A} / \beta$ in Lithoterms 2 and 3.

Hydrochloric test: Dominantly calcareous or semicalcareous.

\section{Assemblage-Lithofacies Relationships (Table 3)}

The feasibility of $A / \beta$ by itself (and later $\left(A / \beta^{\prime}\right)$ is again emphasized. $\mathrm{A} / \mathrm{AP} \beta$ or $\mathrm{A} / \mathrm{AP} \beta^{\prime}$ correspond here to internal variations within the former assemblages, seeing that AP does not exhibit the meaning ("residual") it will possess higher up in the series, when sedimentation takes place beneath the CCD. Cores 138 and 137 exhibit only $\mathrm{A} / \beta$; assemblages without benthos (A/P, A/Az) occur subsequently.

Assemblages $A / \beta$ and $A / \beta^{\prime}$ are coupled with Lithoterms 2 and 3 ; they show some variety depending on the component, i.e., clastic material, bioclastic remains or micropebbles made up by Lithoterm 5 , which prevails singly or in pairs. In this last case, more detailed sampling would probably enable us to separate differently enriched beds; the thickness of the sampled section becomes a significant discriminating factor.

Lithoterm 1 seems to be characterized by the presence of layers where radiolarians have been concentrated; moreover, it frequently yields $\mathrm{A} / \mathrm{Az} 1$ or $\mathrm{A} / \mathrm{Az2}$.

Assemblage $\mathrm{A} / \mathrm{P}$ or $\mathrm{A} / \mathrm{Az}$ is encountered in every lithoterm. Such a feature seems to be normal in the upper interval of the sequences (the most decanted Lithoterm 5) or in the basal interval (Lithoterm 3) with dominating clasticity.

Laminations generally can easily be derived from a given lithoterm; nevertheless, the co-existence of two main components suggests a composite origin (for instance samples 3, 4, 9 on Chart 1A) unless the sampling is too inclusive. 
TABLE 3

Various Dominant Organic and/or Inorganic Assemblages and Their Frequency in Cores 138 to 131 of Hole 398D

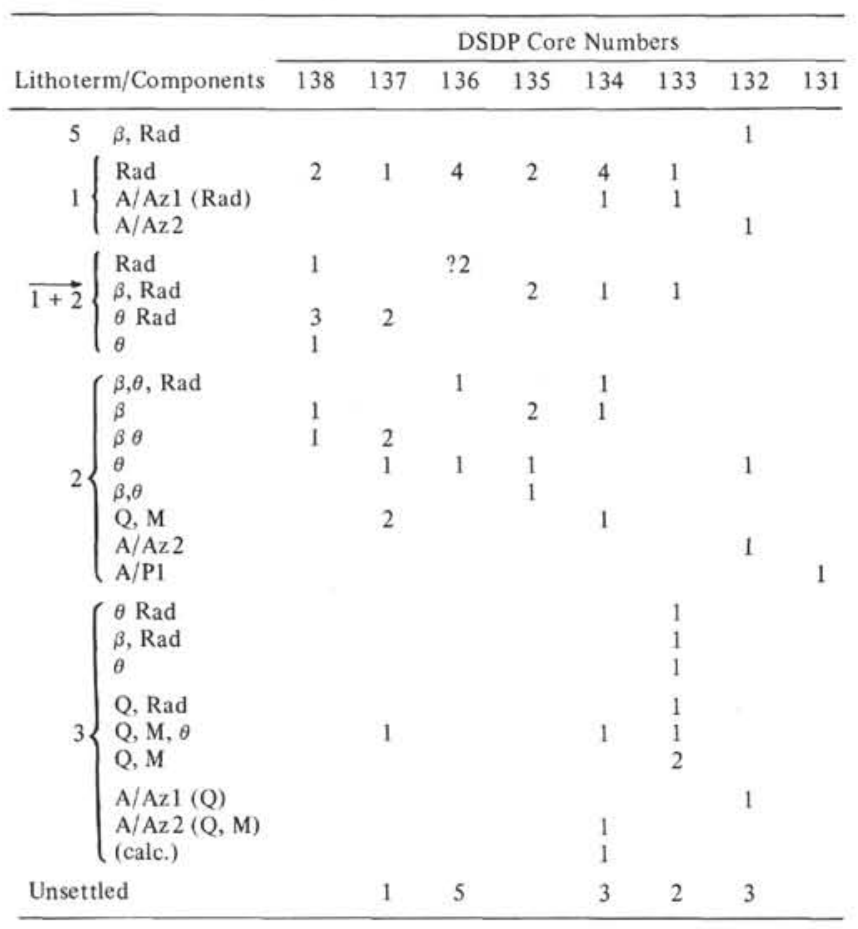

Statistically, a given outstanding component frequently precludes other ones, e.g., radiolarians, or quartz plus mica (plus organic debris incidentally), or mica plus plant debris, or organic debris. These observations support the theory that such an enrichment can be interpreted as the result of the reworking, redeposition, and sorting of pre-existing material.

Table 3 gives an idea of the diversity of the components observed. The abbreviations Rad., $\beta, \theta, \mathrm{Q}, \mathrm{M}$, and calc. represent, respectively: radiolarians, benthos, debris, quartz, mica, and micropebbles of sediment pertaining to Lithoterm 5. Table 3 also gives an idea of the frequency of the various samples within the cores, according to the dominating component (or components).

\section{Unit II: From Cores 130 to $\mathbf{1 0 3}$}

Partly disturbed sequential deposits characterize this unit. On one hand, sequential lithoterms may have been secondarily laminated and graded. On the other hand, sequential successions are interrupted by intrusive turbiditic or slumped bodies. The sedimentation rate here is relatively high $(25 \mathrm{~m} / \mathrm{m} . y$.). Four sub-units are distinguished. The first or lower one and the fourth or uppermost one are based on the mutual behavior of these two disturbing factors. In the first sub-unit, both types occur. The fourth sub-unit consists entirely of a large slump. The second and third sub-units exhibit a different average thickness of the sequences, which are shorter and longer, respectively. More precisely, in the third sub-unit it is mainly the terminal interval of the sequences which becomes thicker and in this way presages the overlying Unit III. The drill site intersected the paleo-CCD during sedimentation of this unit, probably early (near Core 120?).
At the Unit I/II boundary, diagnostic variations affect some biological and sedimentological features: (1) disappearance of nannofossil-rich and radiolarian-rich white colored limestone; (2) spread of plankton; (3) little or no reaction to $\mathrm{HCl}$; and (4) increase in clasticity (and kaolinite), in parallel with either Portuguese or Canadian coeval deposits.

The upper limit of Unit II is defined where sorted sequences disappear in favor of the "dark shales," and where R/AP assemblages become predominant or even exclusive, to the detriment of $T / \beta$ assemblages.

\section{Sub-Unit IIa: From Cores 130 to 121}

In the first sub-unit, the sequential deposits have been disturbed either by secondary laminations or by large turbiditic or slumped intrusions. Four main lithoterms (Figure 3 ) constitute this sub-unit. Lithoterm 1 , when present, is never thick. Lithoterms 2 and 3 are the most developed, as sometimes is Lithoterm 4 (Cores 128,125 , and 124). Lithoterm 3 can generally be subdivided into two parts, a sorted lower part and a crossbedded upper part.

Laminae are the most important features. They are frequently expressed by concentrations of organic or inorganic components, as a probably consequence of local reworking and sorting on the sea floor. As in Unit I, we tried to determine the original lithoterm (designated by an arrow) from which the laminations come, with the help of biological and lithological criteria.

\section{Data Analysis}

\section{Organogenic Components}

$\alpha$ Microfauna: There are some indications (solution marks, carbonate-depleted samples) that deposition took place below or at least near the CCD. It therefore becomes possible to take into account the R/AP assemblages as such i.e., residual assemblages after dissolution effects.

Transported benthos: Usually poor; when relatively rich, it coincides with the presence of debris, either in Lithoterm 2, or more rarely in Lithoterm 3 . It seems to be more abundant in the upper cores. Otherwise, the lack of $\beta$ (resulting in A/AP or A/AP ') is rarely observed. Transported benthos generally occur in Lithoterm 1, sometimes in the clastic and plankton-poor Lithoterm 3. Lagenidae and Gavelinellidae are largely represented. Sometimes Dorothia ouachensis is very abundant, as well as various species of Epistominidae when they have escaped dissolution. Sample 125-2, 8-10 $\mathrm{cm}$ is noteworthy because of its richness in Ophthalmidiidae, a group of fossils rarely present in adjacent samples.

Residual benthos: Always poorly represented.

Plankton: Highly variable, either very poor, or very luxuriant. Frequently abundant in the lower cores where it is coupled with laminations. Never abundant in Lithoterm 1 . The lack of any plankton is frequently observed $\left(\mathrm{A} / \beta^{\prime}, \mathrm{A} / \mathrm{AP}\right.$ ', $\left.\mathrm{A} / \mathrm{Az} 1\right)$; most of the samples belong either to Lithoterm 1 (with or without laminations) or to highly clastic and biodetrital Lithoterm 3 , and rarely Lithoterm 2. 
Radiolarians: From rare to very abundant, but very irregularly distributed. They seem more frequently abundant in the upper cores where they are also more frequently diversified, in this way presaging the next overlying sub-unit. They are well represented in Lithoterm 1. Other lithoterms also are often well supplied, particularly in the laminites or in allochthonous parcels in Lithoterm 4. Recrystallized skeletons predominate widely and occur in all kinds of assemblages; siliceous shells are infrequent, often encountered in the samples where they are abundant, and in every lithoterm, not only when R/AP prevails. Radiolarians are rarely lacking; this is the case in the upper cores especially and mainly occur in every lithoterm, but does not arise with assemblge R/AP.

Dissolution: Solution marks on calcareous shells often are obvious, especially among Epistomina; however, more resistant forms such as some agglutinated shells (Dorothia ouachensis) are also affected.

Reworking: Probable reworked species of foraminifers are frequent, in addition to those obviously reworked as Calpionellids (which are found either in pebbles or in the matrix of the breccia).

$\beta$ Macrofauna: Generally, the biodetrital character is marked; nevertheless (and paradoxically), organic debris do not predominate in samples from coarse turbiditic material. They are particularly abundant in samples with $T / \beta$, where they probably reflect a finer supply. The organic debris consist mainly of pelecypods, rare echinoids, frequent inoceramus, sporadic aptychus, and one belemnite (in Sample 128-4, 39-41 cm). Fish remains are frequent, but not numerous; spicules are rare. Some fractured samples yielded ammonites identified as Barremian.

$\gamma$ Plant debris: Very frequent, at times plentiful (in this case, sometimes associated with abundant mica) in every lithoterm, but preferably and more richly when a turbiditic supply exists. The preservation of vascular and tissular fibers is sometimes perfect.

\section{Inorganic Components}

Clasticity: Quartz is rarely lacking; it becomes sporadic and less abundant in the upper cores (126 to 121). Coarse rounded grains are observed occasionally. The abundance of $\mathrm{Q}$ is associated with Lithoterms 2 and 3; nevertheless, some samples of Lithoterm 1 (with or without laminae) are also prolific (Cores 125 and 127). Lithoterms 3 and 2 sometimes yield abundant quartz and organic debris together.

Glauconite: Frequently present (e.g., Cores 127, 122, and 121), mostly associated with Lithoterm 3 and rarely with 2 or 4 . Generally associated with organic debris. In rare samples, glauconite is observed in Lithoterm 1 (with $\mathrm{A} / \mathrm{AP}, \mathrm{A} / \mathrm{AP} \beta^{\prime}, \mathrm{A} / \mathrm{Az} 2$, or in polluted laminations with $\mathrm{A} / \beta$ or $\mathrm{A} / \beta^{\prime}$ ).

Pyrite: Frequent, sometimes plentiful, it is uncommon in the upper cores; indiscriminantly observed in all lithoterms and with a distribution similar to glauconite. Found in samples generally containing quartz and organic debris. In most cases, pyrite is associated with radiolarians (pyritized shells), sometimes with spicules, rarely with planktonic and sometimes benthic foraminifers, and rarely with micro-gastropods or pelecypods.

Hydrochloric Test: Dominantly calcareous in all cores; nevertheless, the highest sequential interval (Lithoterm 1, with R/AP or A/Az) often shows a weak or negative test.

\section{Assemblage-Lithofacies Relationships (Table 4)}

Assemblage diversity and the multiplicity of depositional conditions (laminations, turbiditic supply) make it difficult for a correlation to be established. If we compare "normal" assemblages (T/ $\beta$ and R/AP), a satisfying correlation is found between R/AP and Lithoterm 1 , and between $T / \beta$ and Lithoterms 2,3 , and 4 . Two unusual samples with $\mathrm{T} / \beta$ in Lithoterm 1 are explained either through bioturbation in contact with Lithoterm 2 (Core 126), or through the presence of exogenic fragments of Lithoterm 1 in Lithoterm 4 (Core 125).

Laminae have been tentatively associated with a given lithoterm, assuming that a correlation similar to that above can be extended to the laminated samples. Two exceptions in Core 129 (A/AP' in Lithoterm 3) probably resulted from errors in estimating $A / \beta^{\prime}$ assemblages, due to low quantities of AP and $\beta$.

For impoverished assemblages ( $\mathrm{A} / \mathrm{P}$ and $\mathrm{A} / \mathrm{Az}$ ), we observed wide scatter in the various lithoterms, with or without laminations. Limited sampling does not allow

TABLE 4

Quantitative Distribution of Assemblages According to the Different Lithoterms in Cores 130 to 121 of Hole 398D

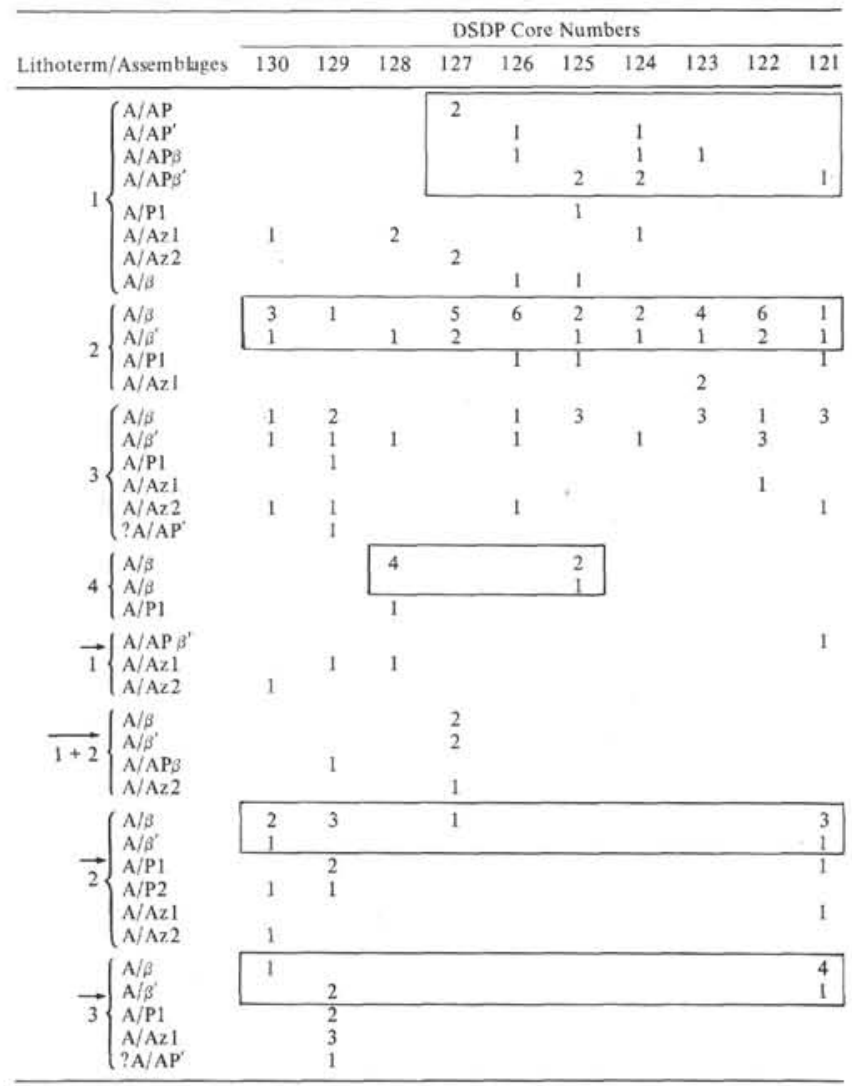


for suitable explanations. Some assemblages were easily situated and their lithology was directly attainable (for instance, Samples 90, 143 in upper; 154, 197, and 234 in middle; $105,115,119$, and 202 in lower sequential intervals). But the bulk has been indirectly assigned to a given lithoterm, according to organic or inorganic data. Such a procedure can evidently be criticized, inasmuch as no logical link seems to emerge. However, the great number of impoverished foraminiferal assemblages coinciding with radiolarian abundance, or with strong clasticity, is striking. Sometimes this can be determined as the result of the rearrangement inside of laminites; but at least as great a number of cases remains which cannot be explained in this way. Thus, we have a rather negative ascertainment at the present stage.

Lastly, we must inquire into the plankton/radiolarian ratio, when those parameters are either absent or abundant: (a) $\pi$ and Rad abundant: always in T/ $\beta$ and in Lithoterms 2 or 3 (4 incidentally), never in $\mathrm{R} / \mathrm{AP}$ and Lithoterm 1, but once in A/P1 and Lithoterm 1. (b) $\pi$ and Rad absent: always in $\mathrm{A} / \beta$ or $\mathrm{A} / \mathrm{Az} 2$ and in Lithoterms 2 or 3 , never in $\mathrm{A} / \mathrm{AP}^{\prime}$ or $\mathrm{A} / \mathrm{AP} \beta^{\prime}$; sometimes in Lithoterm 1 in the shape of A/Az2. (c) $\pi$ abundant, Rad absent: solely in $\mathrm{T} / \beta$ (and $\mathrm{A} / \mathrm{P} 2$ once), always in Lithoterm 2 (generally laminated). (d) $\pi$ absent, Rad abundant: mainly in Lithoterm 1 or in the finest level of 2 , with $\mathrm{A} / \mathrm{AP}^{\prime}, \mathrm{A} / \mathrm{AP} \beta^{\prime}$ or $\mathrm{A} / \mathrm{Az} 1$, but the situation is less distinct than previously. Sometimes this kind of ratio was observed in laminated and very clastic Lithoterm 3, with A/Az1; sometimes in Lithoterm 4 (artificial mixing ?). Lastly, some coupled $\mathrm{T} / \beta^{\prime}$ - Lithoterm 2 or A/Az1 - laminated Lithoterm 2 occur, which we cannot explain at present.

\section{Sub-Unit IIb: From Cores 120 to 117}

Microsequences are the characteristics of this second sub-unit, and three main criteria differentiate it from the preceding one: (1) R/AP assemblages prevail, as a consequence of the previously intersected CCD level; (2) siliceous and recrystallized radiolarians are equally numerous; and (3) the part played by turbiditic or slumped events is not preponderant. When upper sequential intervals become lengthened, we arrived at the next overlying sub-unit. The lithologic sequence of reference of the underlying Sub-unit IIa is also valid (Figure 3).

\section{Data Analysis \\ Organogenic Components \\ $\alpha$ Microfauna}

Transported benthos: Rarely abundant, solely in Lithoterms 2 and 3, occurring with abundant organic debris and radiolarians. Lagenidae and Gavelinellidae are the most important components, sometimes also Gyroidina; scarce Miliolids were probably transported from the neritic or shelf realm, as well as Trocholinas. Assemblages $\mathrm{A} / \mathrm{AP}$ or $\mathrm{A} / \mathrm{AP}^{\prime}$ (i.e., without transported benthos) are found in Lithoterms 1 as usual. Sometimes $\mathrm{A} / \mathrm{AP}$ or $\mathrm{A} \mathrm{AP}^{\prime}$ are observed also in
Lithoterms 2 and 3 (Cores 119 and 117); because the amount of $\beta$ and AP is very low in a calcareous sediment, we can suppose that they have been mis-estimated and are actually $\mathrm{A} / \beta$ or $\mathrm{A} / \beta^{\prime}$ assemblages.

Residual benthos: Uncommon or absent, with the exception of some R/AP in the two upper cores, where an evolution takes place toward the characteristically thick upper sequential intervals of the next sub-unit.

Plankton: Uncommon or absent $\left(\mathrm{A} / \beta^{\prime}, \mathrm{A} / \mathrm{AP}^{\prime}\right.$, $\mathrm{A} / \mathrm{AP} \beta^{\prime}$, and $\mathrm{A} / \mathrm{Az}$ are accordingly numerous); abundant only in Sample 118-1, 132-134 cm, in a slumped structure where a selective $(\pi, M)$ enrichment may have occurred. The lack of plankton is noticeable, occurring with an abundance of radiolarians.

Radiolarians: Very rarely uncommon and never absent; very abundant as a rule (sometimes constituting nearly the entire of the washed residue), together with a wide morphological fan, in R/AP especially. Recrystallized and siliceous skeletons are equally represented.

Dissolution: Solution marks are often still obvious on calcareous shells, particularly on Epistominidae.

Reworking: Frequent.

$\beta$ Macrofauna; A biodetrital character is rarely observed; sometimes organic debris are absent (Core 118). The presence of debris correlates with $T / \beta$ and Lithoterm 3 in nearly all the samples concerned, generally together with glauconite and radiolarians. Inoceramus are very uncommon (Core 120). Fish remains are sporadic. Spicules are almost absent.

$\gamma$ Plant debris: Infrequent and not abundant in Lithoterms 1,2 , or 3 with their corresponding assemblages; exceptionally abundant plant debris together with abundant mica in Lithoterms 2 and 3 of several samples from Core 120.

\section{Inorganic Components}

Clasticity: Quartz generally absent or very rare. Few samples are very clastic, and when it occurs (mainly in the lower core), the clastic material coincides with $\mathrm{A} / \beta$ or $\mathrm{A} / \beta^{\prime}$ in Lithoterms 2 or 3 , often with abundant mica and radiolarians.

Glauconite: Rather infrequent, with the exception of the base of the sub-unit; it is generally connected with Lithoterm 3 , rarely 2 or 4 , exceptionally 1 ; it generally occurs with organic debris.

Pyrite: Very sporadic and uncommon; distribution similar to glauconite; it occurs mainly as pyritized radiolarians.

Hydrochloric test: Partially positive and negative tests are almost equivalent, the first ones predominate in samples with $T / \beta$, the second ones in samples with R/AP; totally positive tests become infrequent, and negative ones spread increasingly.

\section{Assemblage-Lithofacies Relationships (Table 5)}

R/AP-Lithoterm 1 and T/ $\beta$-Lithoterms 2 to 4 correlations (with or without laminations) lead to normalization. Exceptions are rare, although they are somewhat worrying when R/AP is found in Lithoterms 2 or 3, par- 
TABLE 5

Quantitative Distribution of Assemblages According to the Different Lithoterms in Cores 120 to 117 of Hole 398D

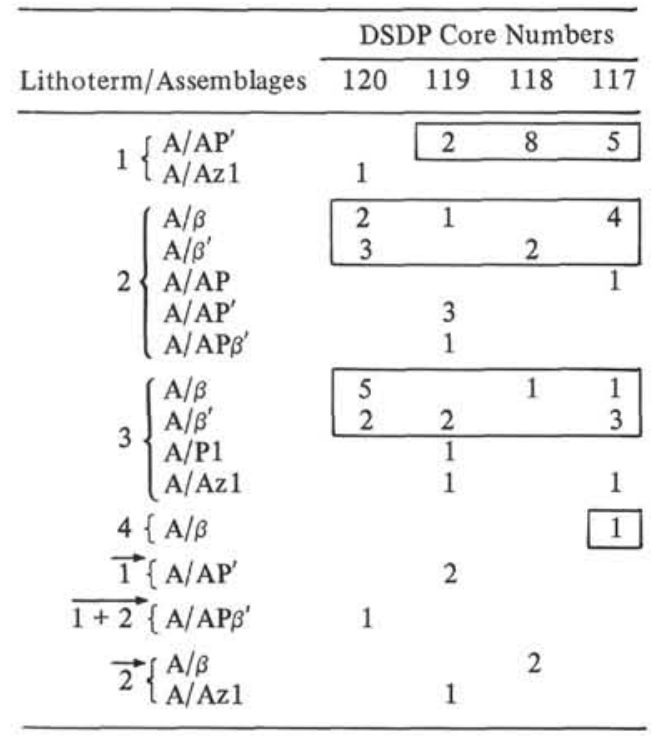

ticularly when this kind of lithology has been established without doubt (Samples 256, 260, and 265). Because of the amount of $\beta$ and AP is very low in a calcareous sediment, we probably are faced with misestimated $T / \beta$ assemblages. In another case (Sample $117-2,113-115 \mathrm{~cm})$, the assemblage may have been disturbed at the time of deposition, because the sample belongs to a very clastic and partially calcareous lower sequential interval.

Impoverished assemblages are uncommon. Radiolarians, as noted above, are never absent (consequently, neither A/P2 nor A/Az2 are observed); and the few $\mathrm{A} / \mathrm{Az} 1$ and the sole A/P1 we have observed are distributed in the different lithoterms without disclosing any rule at the present stage of study.

Lastly, the study of the plankton/radiolarians ratio has been meaningful. Neither $\pi$ and Rad abundant, nor $\pi$ and Rad absent, nor $\pi$ abundant and Rad absent have been encountered. $\pi$ absent and $\mathrm{Rad}$ abundant is, inversely, a very frequently observed ratio, and two kinds of correspondence are evidenced: either with noncalcareous Lithoterm 1 and with $\mathrm{A} / \mathrm{AP}^{\prime}, \mathrm{A} / \mathrm{AP} \beta^{\prime}$, eventually $\mathrm{A} / \mathrm{Az} 1$, or with calcareous or partially calcareous, glauconite-rich and benthos-rich samples in Lithoterm 2 and less frequently 3 , and with $A / \beta^{\prime}$ (and some probably wrongly established $\mathrm{A} / \mathrm{AP}^{\prime}$ and $\mathrm{A} / \mathrm{AP} \beta^{\prime}$, because of small quantities of $\beta$ and AP), eventually A/Azl.

\section{Sub-Unit IIc: From Cores 116 to 106 Pars}

This third sub-unit corresponds to the continuation of a sequential-type sedimentation, but less intensely laminated and with the constant presence and widening of the decarbonated upper sequential intervals. The other two intervals are also often thicker, resulting in an overall characterization as a "macro-sequential" subunit.

The typical features of the upper intervals relate them more to the forthcoming "dark shales" than to underlying Lithoterm 1; we could schematically say that this Lithoterm 1 should lie between Lithoterms II and I of the sub-unit presently being examined.

Lithologic differentiations (Figure 4) have increased here to extremes, and the sub-unit appears as a transitional grouping which retains diminished turbiditic supplies or influences, and foreshadows (but still polluated) the deposition of "dark shales."

\section{Data Analysis}

\section{Organogenic Components}

\section{$\alpha$ Microfauna}

Transported benthos: Highly variable quantitatively. As concerns $T / \beta$ assemblages, we can definitely separate a lower group of cores (116 to 110$)$ where $\beta$ is very rarely abundant, and an upper one (Cores 109 to 106) where, inversely, its abundance prevails. In Cores 109 to 106 , this richness even affects some samples with A/ $\mathrm{AP} \beta$ or $\mathrm{A} / \mathrm{AP} \beta^{\prime}$. Concerning R/AP assemblages, apart from these last exceptions, the part played by $\beta$ is very moderate; nevertheless, it must be emphasized that while not existing previously, $\beta$ now increases progressively from Core 112 upward (in other words, an increased quantity of $\mathrm{A} / \mathrm{AP} \beta$ or $\mathrm{A} / \mathrm{AP} \beta^{\prime}$ is found). The lack of $\beta$ in $\mathrm{A} / \mathrm{AP}$ or $\mathrm{A} / \mathrm{AP}^{\prime}$, or in decarbonated Lithoterm 1 (even 0 ), is frequently observed from Core 116 until Core 113, whereupon $\beta$ becomes sporadic as said above. Lagenidae are generally the most abundant foraminifers; Gyroidina and Gavelinella play a less important part than previously, nevertheless they again become more abundant upwards and more diversified, and they presage the usual Albian-rich microfaunas; Textularidae and Valvulinidae spread out in the same trend.

Residual benthos: Rare or absent in all $\mathrm{T} / \beta$ assemblages until Core 113, and sometimes abundant in R/AP. From Core 112 upward, it changes and even becomes fre-
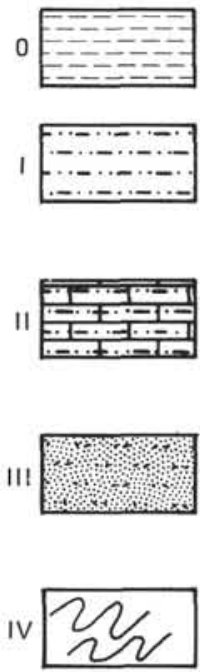

Figure 4. Lithologic sequence of reference for Cores 116 to 106 pars, Hole 398D.

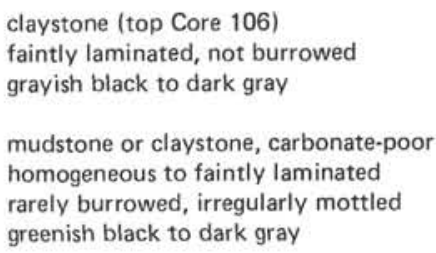

marly nannofossil-chalk to mudstone, carbonate-rich intensely burrowed, usually unmottled occasionally laminated

greenish gray or bluish gray to gray

clastic and/or turbiditic deposit

sand to silt to sandy or silty mudstone ripple lamination, crossbedding or graded bedding

grayish olive or yellowish gray to light gray or multicolored

debris or mud flows (Cores 116 and 112) 
quently abundant in both kinds of assemblages. We must emphasize that true A/AP are missing in this sub-unit.

Plankton: Generally uncommon and often absent (hence numerous $\mathrm{A} / \mathrm{AP}{ }^{\prime}, \mathrm{A} / \beta^{\prime}, \mathrm{A} / \mathrm{AP} \beta^{\prime}$, even $\mathrm{A} / \mathrm{Az} 2$, and never $\mathrm{A} / \mathrm{AP}$ ). However, among the $\mathrm{A} / \beta$, some plankton-rich samples are always observed, which correlate with Lithoterms II and III, even IV; they generally contain abundant radiolarians. This is especially the case with Core 106, where the quantity of samples with $\mathrm{A} / \mathrm{AP} \beta$ has increased at the same time. However, within this sub-unit a very significant feature appears which is not expressible as a quantitative evaluation. It consists of the development (from Core 108 upward) of the "large planktonic forms, coarsely perforated and pustulose" which develop beside the "small" ones. These new planktonic forerunners will increase immediately and produce the most diagnostic group during the last part of the Lower Cretaceous (Ticinella, Rotalipora, etc.).

Radiolarians: Generally abundant and very diversified morphologically, the fact that only one sample devoid of Rad was observed is noteworthy. A gentle and transient decrease occurs in Cores 109 and 108, in samples with mainly $T / \beta$ assemblages. Siliceous radiolarians are less numerous than the recrystallized ones.

Dissolution: Only the "large" newly appeared planktonics give evidence of solution marks (Core 106).

Reworking: Some samples $(117-5,21-23 \mathrm{~cm} ; 112-5$, $144-146 \mathrm{~cm}$; and $112-12-4,18-20 \mathrm{~cm}$ ) yielded reworked species which are Barremian or older.

$\beta$ Macrofauna: The biodetrital character is not very pronounced; debris are very rarely encountered, with the exception of irregularly distributed inoceramus. Concerning these last fossils, their presence in almost all samples with T/B in Cores 112, 109, and 107 is noteworthy. Fish remains are sporadic; nevertheless, they are more regularly present from Core 109 upward, in both $\mathrm{T} / \beta$ and $\mathrm{R} / \mathrm{AP}$ assemblages, and especially in $\mathrm{T} / \beta$ connected with Lithoterms II to IV where they were curiously missing previously.

$\gamma$ Plant debris: Frequent throughout all of the cores, perhaps more so in the upper ones; generally uncommon, sporadically abundant, and indiscriminately distributed in all lithoterms.

\section{Inorganic Components}

Clasticity: Quartz generally not very abundant or absent, with some exceptions (Core 111). When abundant, it occurs indiscriminately in all three lithoterms (I, II, and III) where it is almost always coupled with plant debris and frequently with mica. Abundance of mica is always connected with the presence of plant debris, which is also sometimes abundant.

Glauconite: Practically absent, with the exception of Cores 112 and 106; it occurs in $T / \beta$ or $T / \beta^{\prime}$, or Lithoterms II to IV.

Pyrite: Relatively frequent and sometimes abundant, with the exception of Cores 115,114 , and 109 , pyrite is lacking in Cores 116 and 111; it is indiscriminately distributed in all lithoterms.
Hydrochloric test: Quite variable throughout the cores, a feature which probably reveals great variability in the exogenous supply, and perhaps some irregularity in the solution processes. At the base of the series, positive and negative tests are more or less balanced; the negative test prevails in Cores 114 and 113, where even samples with $T / \beta$ or Lithoterm II are concerned. The ratio is reversed with the turbiditic supply in Core 112 and the base of Core 111. Again, the negative test prevails in Cores 111 to 109 and the extreme base of Core 108. The proportion is reversed again in Cores 108 and 107 , and a balanced proportion is observed in Core 106.

\section{Assemblage-Lithofacies Relationships (Table 6)}

Here again, R/AP-Lithoterm I (and 0 ) and T/ $\beta$ Lithoterms II to IV correlations are confirmed and prevail. Exceptions are uncommon, and the same explanation as before can be proposed when $\mathrm{A} / \mathrm{AP}^{\prime}$ occurs in Lithoterm II $(316,324)$ or A/APB ' in Lithoterm III (354) they could be misestimated $T / \beta^{\prime}$ assemblages, owing to the small quantities of $\beta$ and AP in a calcareous sediment. Conversely, it could be the same for assemblages which are actually $\mathrm{A} / \mathrm{AP} \beta^{\prime}$, but erroneously as T/ $\beta^{\prime}$, in Lithoterm I(331). Nevertheless, some other exceptions cannot be explained at present.

Impoverished assemblages are uncommon in this sub-unit. First, neither A/AP2 nor A/Az2 can exist because radiolarians are never lacking. Only one A/P1 was observed, in Lithoterm II, with a very rich radiolarian and planktonic assemblage; some A/Az1 were encountered in Lithoterms I and II without any possible explanation.

An examination of the plankton/radiolarian ratio substantiates the fact that samples devoid of radiolarians are never encountered, whether plankton is abundant or absent. The other two possibilities are well represented. First, abundance of both plankton and radiolarians (a ratio which was not encountered in Sub-

TABLE 6

Quantitative Distribution of Assemblages According to the Different Lithoterms in Cores 116 to 106 pars of Hole 398D

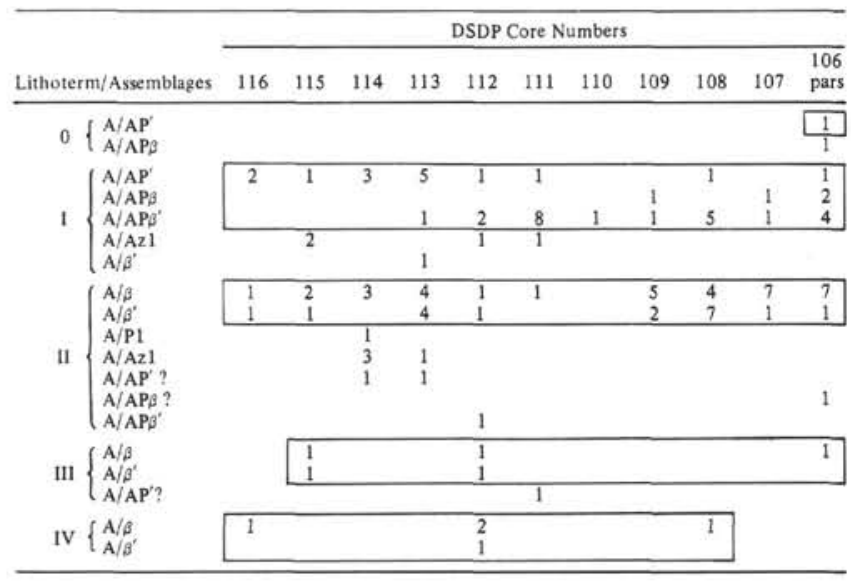


unit IIb) occurs sporadically in all cores (except 109), in $\mathrm{T} / \beta$ or Lithoterms II to IV (with two exceptions, Samples 396, 404). The last case, Rad abundantplankton absent, occurs very frequently in all cores, mainly in $\mathrm{A} / \mathrm{AP}^{\prime}$ and $\mathrm{A} / \mathrm{AP} \beta^{\prime}$ (generally with abundant AP) or in Lithoterms I and 0 , and secondarily sometimes in $T / \beta^{\prime}$, but without any rule at the present stage of knowledge.

If we consider the evolution of assemblages in Subunit IIc from a broad point of view, we must emphasize the far-reaching change which occurs around Cores 112 to 109 and affects various criteria. For instance, $\beta$ becomes more frequent and A/AP is less represented than $\mathrm{A} / \mathrm{AP} \beta$ from Core 112 upward; $\mathrm{AP}$ is more abundant from Core 111 upward; A/Azl is present in Lithoterm I until Core 111; $\beta$ is often abundant and AP more frequently abundant in $T / \beta$; fish remains and spicules are much more frequent from Core 109 upward. It is not easy to find an explanation (if one exists) which could be valid for all these shifting evidences. However we can affirm that two increasing parameters (AP and $\beta$ ) seem to develop concordantly (hence, the small quantity of $\mathrm{A} / \mathrm{P}$ or $\mathrm{A} / \mathrm{Az}$ ), and that we are tempted to interpret this phenomenon, respectively, as the expression of the progressive setting in of the "dark shale" sedimentary regime, and simultaneously as the expression of permanent interference by a turbiditic supply. These influences, while conflicting to a certain extent, would be responsible for the variability we insisted on in the section on "Data Analysis." Thus, we think that we are justified in defining Sub-unit IIc as transitional between two extreme sedimentary regimes.

\section{Sub-Unit IId: From Cores 106 Pars to 104}

This fourth and last sub-unit corresponds to a massive allochthonous complex. As noted above, premonitory events have been found in the underlying cores of Sub-unit IIc. It is not necessary for the present study to work out a lithologic sequence of reference; it is sufficient to refer to the core description made on board.

\section{Data Analysis}

\section{Organogenic Components}

\section{$\alpha$ Microfauna}

Transported benthos: It forms, of course, the main characteristic in such sediments; it is not always abundant, but very diversified. It corresponds to the benthic assemblage which is usually found at this stratigraphic level, with the exception of some species. Lagenidae and Gavelinellidae in the first rank, then Osangularia, Gyroidina, and Valvulineria predominate; Pleurostomellidae and Buliminidae are often present, but are generally few in number.

Residual benthos: AP are remarkably missing (with a minor exception), and this feature is the second characteristic. Note that they will reappear in Core 103, where they are generally abundant in R/AP assemblages.

Plankton: Its abundance, sometimes very great, forms the third characteristic; it is rarely lacking (top of Core 106), and it will abruptly lessen or disappear from the base of Core 103 upward.

"In-situ" or reworked microfauna: Benthic or planktonic unquestionably reworked specimens do exist in several samples (e.g., Spirillina neocomiana, Dorothia ouachensis, some small-sized Hedbergellas that are Neocomian or Barremian). But we may wonder if all the microfauna observed have not been reworked, too. The question is a weighty one because the age of the formation is based on the benthic and planktonic species we found in the samples. This question was answered in the Biostratigraphy section.

Radiolarians: Their scarcity and even their absence are the fourth characteristic of this sub-unit. Their morphologic diversity is small. Recrystallized tests are uncommon.

Dissolution: Several times (particularly in Core 105) solution traces are observed, even in benthic forms, but mainly in the "large" planktonic shells.

$\beta$ Macrofauna: Debris are paradoxically very sparsely represented (with only one exception). Aptychus are rare, Inoceramus few, other debris are as usual. Fish remains are very frequent, sometimes in abundance. Spicules are infrequent. One piece of Rhyncholites (cf. Akidocheilus ambiguus Till, 1907) was found (Sample $105-3,57-59 \mathrm{~cm})$.

$\gamma$ Plant debris: Almost absent in the allochthonous materials; they become frequent as soon as the base of Core 103 is reached.

\section{Inorganic Components}

Clasticity: Quartz sporadically abundant; mica is absent or rare.

Glauconite: Very frequent, especially in Core 104; it disappears from the base of Core 103 upward.

Pyrite: Absent in Cores 104 and 105.

Hydrochloric test: Very few samples in Cores 105 and 104 are negative.

\section{Assemblage-Lithofacies Relationships (Table 7)}

The turbiditic and slumped event, which was foreshadowed at least as early as Core 107 is fully developed in the top of Core 106 and in Cores 105 and 104. A/ $\beta$ assemblages predominate almost exclusively in Lithoterm IV which conventionally gives its name to this type of sediment (only one $\mathrm{A} / \beta^{\prime}$ was observed in probably packed Lithoterm II).

Three samples stand apart, because they are almost devoid $(437,439)$ or entirely devoid (419) of planktonics. They probably belong to a pelagic argillaceous sediment derived from a Lithoterm I or 0 which was packed in the slumping flow.

In the full length of the section on "Data Analysis," Core 103 is quite distinct and needs a special judgment. In this core, two parts can be distinguished (from the base to Sample 103-5, 48-50 cm and from Sample 103-3, $122-124 \mathrm{~cm}$ to the top), especially with the help of the amount of radiolarians and the amount of AP in R/AP, the frequency of clastic samples and the nature of hydrochloric tests. As a whole, Core 103 is very differ- 
TABLE 7

Quantitative Distribution of Assemblages According to the Different Lithoterms in Core 103 of Hole 398D

\begin{tabular}{|c|c|c|}
\hline & & $\begin{array}{l}\text { Sample Number } \\
\text { (Author's Chart 1) }\end{array}$ \\
\hline & According t & $\begin{array}{l}\text { to the lithologic reference } \\
\text { for Sub-Unit IIc }\end{array}$ \\
\hline I & $\begin{array}{l}\mathrm{A} / \mathrm{AP} \\
\mathrm{A} / \mathrm{AP} \\
\mathrm{A} / \mathrm{AP} \beta \\
\mathrm{A} / \mathrm{AP} \beta^{\prime}\end{array}$ & $\begin{array}{l}463 \\
446,448,458 \\
456 \\
461\end{array}$ \\
\hline II & $\left\{\begin{array}{l}\mathrm{A} / \beta \\
\mathrm{A} / \beta^{\prime} \\
\mathrm{A} / \mathrm{AP} \beta \\
\mathrm{A} / \mathrm{AP} \beta^{\prime}\end{array}\right.$ & $\begin{array}{l}447,452 \text { to } 454,459,460 \\
449 \\
450,451,457 \\
462\end{array}$ \\
\hline & $\begin{array}{r}\text { According t } \\
f\end{array}$ & $\begin{array}{l}\text { to the lithologic reference } \\
\text { for Sub-Unit IIIa }\end{array}$ \\
\hline D & $\mathrm{A} / \mathrm{AP}^{\prime}$ & 448 \\
\hline C & $\left\{\begin{array}{l}\mathrm{A} / \mathrm{AP}^{\prime} \\
\mathrm{A} / \mathrm{AP} \beta \\
\mathrm{A} / \mathrm{AP} \beta^{\prime}\end{array}\right.$ & $\begin{array}{l}446,458 \\
456 \\
461\end{array}$ \\
\hline B & $\left\{\begin{array}{l}\mathrm{A} / \beta \\
\mathrm{A} / \beta^{\prime} \\
\mathrm{A} / \mathrm{AP} \beta \\
\mathrm{A} / \mathrm{AP} \beta^{\prime}\end{array}\right.$ & $\begin{array}{l}447,452 \text { to } 454,459 \\
449 \\
450,451,457 \\
462\end{array}$ \\
\hline $\mathrm{C}^{\prime}$ & $\mathrm{A} / \mathrm{AP}$ & 463 \\
\hline S & $\mathrm{A} / \beta$ & 460 \\
\hline
\end{tabular}

ent from the other cores in Sub-unit IId and seems to be closer to the cores of the overlying Unit III. As a matter of fact, Core 103 might have been placed in Sub-unit IId because of the large number of samples with $T / \beta$ assemblages, or at least with polluted R/AP $(\mathrm{A} / \mathrm{AP} \beta$, $\mathrm{A} / \mathrm{AP} \beta^{\prime}$ ), whereas these assemblages are not found above. Thus, this core looks like a very intermediary core whose sediments already belong to the sedimentary regime which is going to prevail, but in which the large slumped episode of Cores 105 and 104 is still felt temporarily.

\section{Unit III: From Cores 103 to 79}

This unit belongs to a new sedimentary regime. "Dark shales" are accumulated with a high rate of sedimentation (75 to $100 \mathrm{~m} / \mathrm{m} . \mathrm{y}$.); they were deposited underneath the CCD, with a permanent but diffuse allochthonous supply (probably partially dissolved). At the end of this unit, the sediments progressively become more calcareous, because of the changing depth of the CCD or an increasing supply as discussed further.

In the lithologic sequence of reference (Figure 5), Lithoterm C predominates; it is black and not calcareous when typical, with prevailing R/AP assemblages (A/AP' being the most typical). Lithoterm D, mainly present in the lower cores, more or less corresponds to Lithoterm B, which develops in the cores with a greater calcareous supply. Lastly, Lithoterm $\mathrm{C}^{\prime}$ corresponds to the samples with a laminitic structure and whose assemblages often display a selective enrichment of a given organic or inorganic component. On the whole, lami- claystone, mainly carbonate depleted $(<1 \%)$

massive (to very fine laminations)

not burrowed (or never intensely)

black, grayish black, dark gray, olive-black

claystone, not expanding, mostly carbonate-rich sharp basal contact, grading upward to $\mathrm{C}$ laminated or graded texture

medium gray, dark gray, to light gray

claystone to marly chalk, carbonate-rich homogeneous to faintly irregularly laminated intensely or moderately burrowed grayish olive-green to yellow-olive-green

claystone as $\mathrm{C}$, mainly carbonate-rich parallel or wavy laminations, intercalated mainly between $C$ and $C$, rarely $C$ and $B$ not burrowed

dark gray, medium gray, to greenish gray

calcareous mudstone to marly chalk with mud or debris flows or turbiditic material burrowed, sometimes sandy laminations sharp basal contact (mainly on C, rarely on B) light greenish gray, grayish olive green

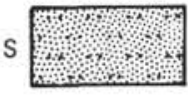

mud-chip siltstone or sandstone (Cores 97 and 101) sometimes graded varicolored grains

Figure 5. Lithologic sequence of reference for Cores 103 to 88 of Hole $398 D$.

nated structures (sometimes very fine) are frequent and are very characteristic of Unit III. The last two lithoterms play a minor part and are sometimes missing.

The lower boundary here includes Core 103 which, as noted above, has not been included in the Sub-unit IId. The upper boundary remains more subjective and corresponds to a moment in the sedimentary evolution when lithologic and biocoenotic differentiations started to change, and diminish, and to prefigure the more homogeneous behavior which will characterize the overlying beds.

\section{Sub-Unit IIIa: From Cores 103 to $\mathbf{8 8}$}

The first sub-unit corresponds to the most representative development of the dark shales (or so-called "black shales"), although the typical deposit does not actually compose the major thickness. The lithological sequence mainly involves Lithoterms $\mathrm{C}, \mathrm{C}^{\prime}$, and $\mathrm{D}$; the last two are best developed in the lower cores. A diffuse calcareous supply is almost continuously perceptible over the full length of this sub-unit; the supply is more significant from time to time, e.g., Cores 100, 98, 96 and 92, and, of course, the base of Core 103.

\section{Data Analysis}

\section{Organogenic Components}

\section{$\alpha$ Microfauna}

Transported benthos: Generally missing and sporadically present in $\mathrm{A} / \mathrm{AP} \beta$ or $\mathrm{A} / \mathrm{AP} \beta^{\prime}$ where it is rare, with the relative exception of Core 103, with the exception of Cores 96 and 93 (where these assemblages are rather numerous), and Core 92 (where $\beta$ becomes so 
abundant that even some $T / \beta$ can be distinguished). As a whole, the same families or genera are observed as in the underlying sub-unit, with some specific species which characterize Albian or "Gault" association. However, the dissolution had a considerable impoverishing effect, and the "survivors" are often flooded to some extent in the bulk of the agglutinated residual association.

Residual benthos: Rarely absent (very few A/P or $\mathrm{A} / \mathrm{Az}$ are observed, generally in calcareous Lithoterms $\mathrm{C}, \mathrm{C}^{\prime}$, or $\mathrm{D}$ ), and very often common to abundant, as might be expected.

Plankton: Generally lacking (hence the great quantity of $\mathrm{A} / \mathrm{AP}{ }^{\prime}$ or $\mathrm{A} / \mathrm{AP} \beta^{\prime}$, and even $\mathrm{A} / \mathrm{Az}$ ). A few rare examples are found in about 10 samples with A/AP or mainly A/AP $\beta$; these samples belong to Lithoterms C, $\mathrm{C}^{\prime}$, or $\mathrm{D}$ and rarely to $\mathrm{S}$ or $\mathrm{Tl}$. The Heterohelicidae family seems to start here (Core 97), in the shape of some rare exemplars of Gümbelina. In the stratigraphic section, we emphasized that the population of Globigerinidae was different, on the whole, from the Aptian one. Thus, the entire pelagic population has been renewed.

Radiolarians: Almost permanent, abundant, and morphologically diversified, they are the very characteristic of the microfaunal assemblage. Only one sample is devoid of radiolarians, as well as of other microfossils, in Lithoterm C. They are dominantly siliceous.

Dissolution: Solution marks were observed in only one sample $(88-6,27-29 \mathrm{~cm})$ on planktonic exemplars, in a laminated Lithoterm $C^{\prime}$.

$\beta$ Macrofauna: The biodetrital character is weakly expressed and found only in a few samples from Lithoterms C, $C^{\prime}$, or $\mathrm{D}$, with selectively enriched laminations. Debris are lacking above Core 92. Ammonites were abundantly recovered and enabled an early and a middle Albian age to be recognized. Fish remains are almost permanently present. Spicules (mainly of Spongiae, but also of other organisms such as Gorgonae and Ascidias) are present at the base of the sub-unit.

Plant debris: Almost permanently present, and sometimes abundant, with the exception of the three upper cores.

\section{Inorganic Components}

Clasticity: Quartz is very rare or absent, with the exception of the base of Core 103 and of a few samples belonging to laminites or Lithoterm $\mathrm{Tl}(560)$ or S (523). Mica is abundant in some samples of Lithoterms C, $\mathrm{C}^{\prime}$, or $\mathrm{D}$; in these cases, plant debris are always present and sometimes abundant $(510,531,548,562,621)$.

Glauconite: Missing.

Pyrite: Almost permanent, with the exception of some samples with $T / \beta$ in Cores 92 and 96 , i.e., two cores where the exogenous supply is especially perceptible.

Gypsum: Frequent; generally occurring in laminations within the sediment.

Hydrochloric test: The non-calcareous test dominates here, with the exception of Cores 98 to 92 , an interval where the calcareous/non-calcareous ratio is sometimes balanced or even reversed, because of the exogenous supply.

\section{Assemblage-Lithofacies Relationships (Table 8)}

This sub-unit is the most effective part of the series drilled. Thus, it seems advisable to investigate in some detail the relationships between faunal assemblages and sedimentary facies.

It has already been established that some characteristics predominate almost permanently: $\mathrm{A} / \mathrm{AP}^{\prime}$ and $\mathrm{A} / \mathrm{AP} \beta^{\prime}$, negative hydrochloric test, high frequency of plant debris and pyrite, abundance of radiolarians, lack of planktonic foraminifers. Other dominating features are less permanent: abundance of AP, the presence of fish remains, and an absence or uncommonness of $\beta$. As a whole, we can assert that the leading characteristic is made up by the doublet: $\mathrm{A} / \mathrm{AP}^{\prime}$ and hydrochloric negative test, i.e., the assemblage and the behavior of typical Lithoterm C. In many cores $(102,101,97,95,91,89$, and 88 ) the samples belong to Lithoterm $C$ one out of two times; conversely, $\mathrm{T} / \beta$ is very limited (in Core 92 alone).

If we pursue the analyses of the R/AP assemblages, we note that, if the $\mathrm{A} / \mathrm{AP}^{\prime}$-negative hydrochloric test correlation is considered normal, other kinds of correlations have to be considered as exceptions (the first three cases hereunder) or anomalies (last two cases):

1) A/AP with non-calcareous hydrochloric test; these samples $(544,546,598)$ are particularized by the presence of plankton, which appears rather unusual in such a sediment.

2) A/AP $\beta$ with non-calcareous hydrochloric test; these samples $(507,531,539,553)$ are particularized by the presence of plankton and benthos, which also seems rather unusual. Quartz, mica, and debris are frequent.

3) $\mathrm{A} / \mathrm{AP} \beta^{\prime}$ with non-calcareous hydrochloric test; these samples $(468,483,491,494,496,509,518,527$, $561,569,571,576,596,599,602)$ are particularized by the presence of benthos, still rather unusual. Quartz and debris are frequent.

4) $\mathrm{A} / \mathrm{AP}^{\prime}$ with calcareous hydrochloric test; these samples are by far the most numerous and occur in Lithoterms C, $\mathrm{C}^{\prime}$, and D. Sometimes quartz and debris are present; however, they probably owe their positive hydrochloric test to fine calcareous grains which are either disseminated in the sediment or concentrated in some laminae. This kind of sediment, with a sharp basal contact, is assigned a turbiditic origin.

5) A/AP with calcareous hydrochloric test; these samples are particularized by the presence of plankton.

If we now examine the last possible arrangement (563, 621) we are faced with assemblages which we consider as normal in calcareous sediments, i.e., $\mathrm{A} / \beta(580$, 581), $\mathrm{A} / \mathrm{AP} \beta$ (486, 560), and $\mathrm{A} / \mathrm{AP} \beta^{\prime}$ (523). These samples are particularized by the presence of benthos, plankton, and debris, often with glauconite and quartz; they occur in Lithoterms $\mathrm{Tl}$ or S. The ultimate arrangement (i.e., $T / \beta$ in non-calcareous sediments) theoretically has little probability and was not actually encountered. 
TABLE 8

Distribution of Assemblages According to the Different Lithoterms in Cores 102 to 88 of Hole 398D

\begin{tabular}{|c|c|c|c|c|c|c|c|c|c|c|c|c|c|c|c|c|}
\hline \multirow{2}{*}{\multicolumn{2}{|c|}{ Lithoterm/Assemblages }} & \multicolumn{15}{|c|}{ DSDP Core Numbers } \\
\hline & & 102 & 101 & 100 & 99 & 98 & 97 & 96. & 95 & 94 & 93 & 92 & 91 & 90 & 89 & 88 \\
\hline C & $\left\{\begin{array}{l}\mathrm{A} / \mathrm{AP} \\
\mathrm{A} / \mathrm{AP}^{\prime} \\
\mathrm{A} / \mathrm{AP} \beta \\
\mathrm{A} / \mathrm{AP} \beta^{\prime}\end{array}\right.$ & $\begin{array}{l}7 \\
1\end{array}$ & $\begin{array}{l}5 \\
1\end{array}$ & 4 & $\begin{array}{l}4 \\
1 \\
1\end{array}$ & & 3 & 3 & $\begin{array}{l}1 \\
5\end{array}$ & $\begin{array}{l}1 \\
1\end{array}$ & 1 & $\begin{array}{l}3 \\
1\end{array}$ & 3 & $\begin{array}{l}1 \\
1 \\
3\end{array}$ & $\begin{array}{l}4 \\
1 \\
\end{array}$ & 5 \\
\hline \multirow[t]{2}{*}{$\mathrm{C}^{\prime}$} & $\left\{\begin{array}{l}\mathrm{A} / \mathrm{AP} \\
\mathrm{A} / \mathrm{AP} \\
\mathrm{A} / \mathrm{AP} \beta \\
\mathrm{A} / \mathrm{AP} \beta^{\prime}\end{array}\right.$ & $\begin{array}{l}3 \\
1\end{array}$ & 2 & 1 & 6 & $\begin{array}{l}1 \\
3 \\
\end{array}$ & $\begin{array}{l}3 \\
1\end{array}$ & $\begin{array}{l}1 \\
2 \\
3\end{array}$ & 3 & 1 & 5 & & & & & $\begin{array}{l}1 \\
1\end{array}$ \\
\hline & $\begin{array}{l}\mathrm{A} / \mathrm{Az} 1 \\
\mathrm{~A} / \mathrm{Az} 2\end{array}$ & & & & & & 1 & 4 & & & 1 & & & & & \\
\hline \multirow[t]{2}{*}{ D } & $\left\{\begin{array}{l}\mathrm{A} / \mathrm{AP} \\
\mathrm{A} / \mathrm{AP} \\
\mathrm{A} / \mathrm{AP} \beta \\
\mathrm{A} / \mathrm{AP} \beta^{\prime}\end{array}\right.$ & & 2 & $\begin{array}{l}3 \\
3\end{array}$ & 1 & & & 1 & $\begin{array}{l}1 \\
1\end{array}$ & & & 1 & & & & \\
\hline & $\begin{array}{l}\mathrm{A} / \mathrm{AP} 1 \\
\mathrm{~A} / \mathrm{Az} 1 \\
\mathrm{~A} / \beta\end{array}$ & & & & 2 & & & & & & & $\begin{array}{l}1 \\
1\end{array}$ & 1 & & & \\
\hline \multicolumn{2}{|c|}{$\mathrm{T} 1\left\{\begin{array}{l}\mathrm{A} / \beta \\
\mathrm{A} / \mathrm{AP} \beta\end{array}\right.$} & & & & & & & & & & 1 & 2 & & & & \\
\hline & $\left\{\begin{array}{l}\mathrm{A} / \mathrm{AP} \beta \\
\mathrm{A} / \mathrm{AP} \beta^{\prime}\end{array}\right.$ & & & 1 & & & 1 & & & & & & & & & \\
\hline
\end{tabular}

In summary, we can schematize our data as follows:

Negative test: Either with $\mathrm{A} / \mathrm{AP}$ ' or A/AP: Lithoterms $\mathrm{C}$ or $\mathrm{D}$, sometimes $\mathrm{C}^{\prime}$; or, with $\mathrm{A} / \mathrm{AP} \beta$ or $\mathrm{A} / \mathrm{AP} \beta^{\prime}$ : Lithoterms $\mathrm{C}, \mathrm{C}^{\prime}$ or $\mathrm{D}$.

Positive test: Either Lithoterm $\mathrm{C}$ or $\mathrm{C}$ ', with "calcareous grains": A/AP'; or, Lithoterm C or $\mathrm{C}^{\prime}$, with $\beta, \pi$, debris: various R/AP; or, Lithoterm D, with $\beta$, $\pi$, debris; "calcareous grains": $\mathrm{A} / \mathrm{AP}$ ', $\mathrm{A} / \mathrm{AP} \beta^{\prime}, \mathrm{A} / \beta$.

Lastly, the assemblages without benthos $(\mathrm{A} / \mathrm{P}$ and $\mathrm{A} / \mathrm{Az}$ ) are infrequent in this sub-unit. $\mathrm{A} / \mathrm{Azl}$ is the most frequent and was observed in Lithoterm $\mathrm{C}^{\prime}$ and $\mathrm{D}$; A/Pl was observed once (579) in Lithoterm D. As can be expected, samples devoid of radiolarians cannot be numerous in such a sediment: $\mathrm{A} / \mathrm{Az} 2$ was observed once (559) in Lithoterm C ', and A/P2 was not encountered.

Among sedimentary processes which led to the deposits observed, the exogenous supply is most important, following the dark shales themselves. The exogenous supply is responsible for the diversification of biocenotic assemblages as well as lithologic facies. If we leave aside the samples which clearly belong to the residual deposit (non-calcareous and with A/AP'), we can see that the exogenous supply occurs permanently. It is revealed by sedimentological structures and figures and, from our point of view, is manifested by various components such as calcareous benthos, plankton, organic debris, and sometimes quartz and glauconite. If we cannot detect such perceptible components in the sieved residue, we nonetheless must admit the presence of fine calcareous particles.

Upward from cores where A/AP' predominate, we find this calcareous supply increased, while the black color tones down and the lamination becomes more pronounced. In this way, Cores 100 to $98,96,93$, and 92 successively correspond to a renewed supply, going so far as to contain actual small-sized turbidites. This evolutive curve is the reverse of the curve expressing the variation in the frequency of typical Lithoterm C, as has already been said.

In the hierarchy of sedimentary processes, third place goes to the lamination and to the sorting and selective enrichment which follow. Hence, the occurrence of numerous Lithoterms $\mathrm{C}^{\prime}$ and the varying behavior of the different R/AP assemblages, as has been related in detail. Frequently, the distinction of $C^{\prime}$ from $C$ or $D$ is rather a matter of thinness and visibility of the laminae; sometimes Lithoterm $\mathrm{Tl}$ also displays some laminations. On a large scale, the intensity of this sedimentary phenomen seems to decrease considerably in the upper cores, from Core 92 upward.

\section{Sub-Unit IIIb: From Cores 87 to 79}

This second sub-unit represents the first stage in the progressive "pollution" of the "dark shales" by turbiditic material: $\mathrm{T} / \beta$ assemblages and calcareous with $\mathrm{HCl}$ treated samples become more frequent; however, neither one nor the other of these criteria predominates. Another aspect, which is not actually characteristic, evolves independently at the same time and gives evidence of a progressive change; namely, solution marks become more perceptible.

The lithological sequence of reference (Figure 5) becomes more diversified and laminations are more developed. Nevertheless, Lithoterm C still predominates. It is possible that dissolution processes may be less significant from now on, and might be responsible, to some extent, for the apparent increase in the transported material. This is the crucial point of discussion, as developed below. 


\section{Data Analysis}

\section{Organogenic Components}

\section{$\alpha$ Microfauna}

Transported benthos: Rare, with the exception of the two lower cores and Lithoterm Tl; it occurs with abundant planktonics in Core 86. The same genera and species as before are present here, but they are more numerous and diverse. Transported benthos in R/AP assemblages is quantitatively low, while giving rise to a relatively great number of $\mathrm{A} / \mathrm{AP} \beta$ or $\mathrm{A} / \mathrm{AP} \beta^{\prime}$ in the different cores.

Residual benthos: Relatively frequent occurrences in the lower core and sporadic occurrences in the others, but the difference is great compared with underlying Sub-unit IIIa.

Plankton: Generally absent (hence, the small number of $\mathrm{A} / \beta$ and $\mathrm{A} / \mathrm{AP}$ ); Core 86 is again an exception, with its abundant exemplars in all the $A / \beta$ assemblages observed, and with abundant transported benthos; the same occurs in Core 81 (703). Lastly, abundant plankton was encountered in one sample (675) found in selectively enriched laminations. Solution marks are frequent.

Radiolarians: Generally common to abundant; nevertheless, they are never conspicuously abundant and diversified, or absent.

$\beta$ Macrofauna: Biodetrital samples are extremely rare, with the exception of Core 82 . Organic debris are mainly localized either in laminae or at the base of the mud turbidites. Fish remains are quite permanent in R/AP. Spicules are irregularly present; they are especially abundant in Core 82 ; they sometimes come from various organisms, such as Spongiae, Gorgonids, Alcyonnids, and Holothurids, Some ammonites enable the middle Albian to be recognized.

$\gamma$ Plant debris: Rather frequent and sometimes abundant; they are coupled with R/AP in Lithoterm C or in the laminations. Megaspores are encountered in Core 86 (642).

\section{Inorganic Components}

Clasticity: Quartz is rather permanently present, but scarcely abundant (in this case, it is generally correlated with Lithoterm $\mathrm{C}$ or with laminations and, once, with the lower layers of mud turbidites).

Glauconite: Almost absent.

Pyrite: Nearly permanent and often abundant (especially in the upper part of this sub-unit), particularly in samples with R/AP.

Gypsum: Frequent, especially from Core 82 upwards.

Hydrochloric test: The non-calcareous test predominates, although with numerous exceptions, particularly in the lower cores. Samples with $\mathrm{T} / \beta$ are calcareous as a rule, but we also find calcareous tests in samples with $\mathrm{A} / \mathrm{AP} \beta$ or $\mathrm{A} / \mathrm{AP} \beta^{\prime}$, or even $\mathrm{A} / \mathrm{AP}^{\prime}$ (Core 80 ).

\section{Assemblage-Lithofacies Relationships (Table 9)}

The R/AP-Lithoterm $\mathrm{C}$ and $\mathrm{T} / \beta$-Lithoterm $\mathrm{B}$ or $\mathrm{Tl}$ usual correlations may have some exceptions. We can see that most of the samples with R/AP in Lithoterm C
TABLE 9

Distribution of Assemblages According to the Different Lithoterms in Cores 87 to 79 of Hole 398D

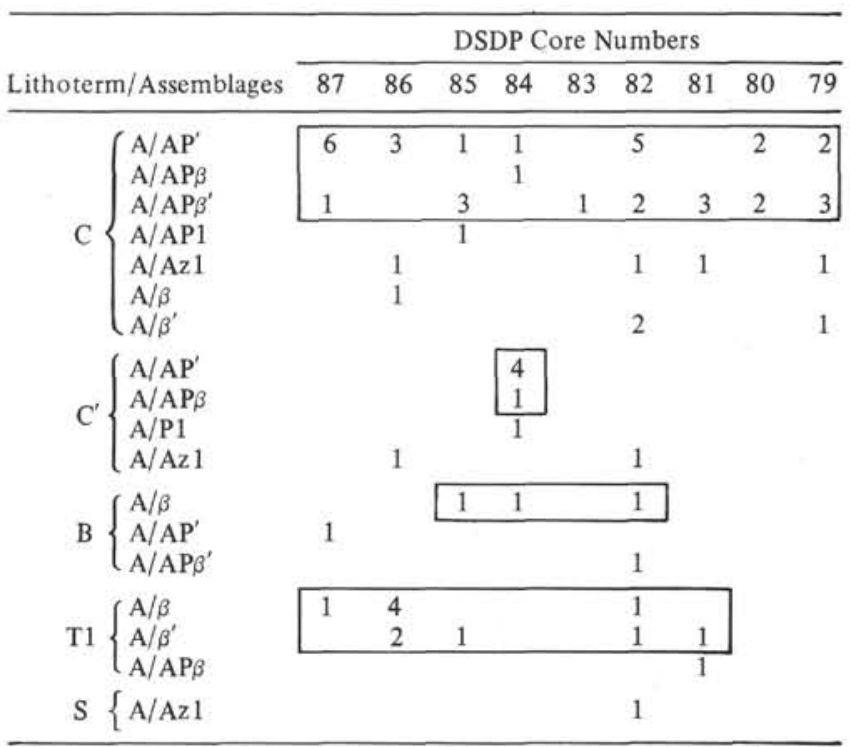

have a negative hydrochloric test; exceptional cases generally belong to polluted or laminated sediments. Samples with $T / \beta$ or $T / \beta^{\prime}$ are even encountered in this Lithoterm C.

Some typical samples seem to persist, which were deposited underneath the $\mathrm{CCD}$; they yield $\mathrm{A} / \mathrm{AP}^{\prime}$ (or $\mathrm{A} / \mathrm{Pl}$ ) assemblages, have a negative hydrochloric test, and are black in color $(664,693,715,720,723)$.

The laminated samples (or $\mathrm{C}^{\prime}$ ) display various kinds of selective enrichment (debris, benthos, plankton, mica, calcareous grains).

Lithoterms B and Tl generally display $T / \beta$ assemblages in a more-or-less calcareous sediment, but there are some exceptions which can be explained (small quantities of $\beta$ and AP for Sample 640, where A/AP' could actually be $T / \beta^{\prime}$ ) or not (Samples 687 with $\mathrm{A} / \mathrm{AP} \beta$ or 672 with $\mathrm{A} / \mathrm{AP}^{\prime}$ ), at the present stage of knowledge.

All these considerations and indecisions are clear evidence of some hindrance when we try to maintain the criteria we used previously; the lithological terms seem to be adulterated, as will be suspected increasingly later on.

\section{Unit IV: From Cores 78 to $\mathbf{7 1}$}

This unit looks like a hinge in the course of the progressive installation of calcareous series and the decrease of the sedimentation rate. $\mathrm{T} / \beta$ now predominate; however, some samples are still found in sediments which agree with the characteristics of a typical decarbonated residual deposit.

As a result, we encounter a great deal of indecision when we try to classify the assemblages into one or another category, as well as when we try to put the samples into this or that lithoterm.

The dominance of $T / \beta$ and the rarity of R/AP place this unit beside the overlying one, which appears frankly pelagic. However, owing to the still distinct lithoterms 
and the importance of laminated Lithoterm $C^{\prime}$, this unit is still connected with the previous sequential deposits of Unit III.

The last lithological sequence of reference (Figure 5) will also be utilized here. But the lithoterms will be modified by a strong adulteration resulting from the preponderant influence of calcareous material (either more abundant or less dissolved, or both).

\section{Sub-Unit IVa: From Cores 78 to 74}

The evolution which began in the underlying sub-unit continues here. The material brought in becomes more perceptible, enabling a new evolutionary stage to be discerned. $T / \beta$ assemblages are always present; the $T / \beta$ $\mathrm{A} / \mathrm{AP}$ ratio will even be reversed in Core 74 (which could in fact belong to the next sub-unit), and this dominance of $T / \beta$ over $R / A P$ will henceforth subsist.

\section{Data Analysis}

\section{Organogenic Components}

\section{$\alpha$ Microfauna}

Transported benthos: Rarely abundant; however, $\mathrm{T} / \beta$ assemblages are always present, and the presence of $\beta$ in $\mathrm{R} / \mathrm{AP}$ assemblages is frequent (hence, numerous $\mathrm{A} / \mathrm{AP} \beta$ or $\mathrm{A} / \mathrm{AP} \beta^{\prime}$ ). Genera and species are the same as before.

Residual benthos: Generally rare in R/AP and frequently absent in $T / \beta$ assemblages.

Plankton: Very poor and often absent (hence, numerous $\left.\mathrm{T} / \beta^{\prime}, \mathrm{A} / \mathrm{AP}{ }^{\prime}, \mathrm{A} / \mathrm{AP} \beta^{\prime}\right)$, with the exception of two samples $(759,776)$ with $\mathrm{T} / \mathrm{B}$ in debris flows $(\mathrm{Tl})$ or in laminated Lithoterm B.

Radiolarians: Always present and generally common to abundant.

Dissolution: Solution marks are frequently observed, especially in the lower core.

$\beta$ Macrofauna: The biodetrital nature is very weak, samples with debris occur sporadically and correspond to debris flows (Lithoterm $\mathrm{Tl}$ ) or to a diffuse supply (Lithoterms B and C). Fish remains almost permanent. Spicules are more sporadic. Ammonites are uncommon.

$\boldsymbol{\gamma}$ Plant debris: Very sporadic and uncommon; in two laminated samples, abundant plant debris and mica are encountered together.

\section{Inorganic Components}

Clasticity: Quartz is almost permanent, never abundant. We note several samples with $\mathrm{T} / \beta$ or $\mathrm{A} / \mathrm{Az}$ containing rather coarse and rounded grains in Lithoterm $\mathrm{C}$ in the lower core.

Glauconite: Not observed.

Pyrite: Almost permanent, frequently abundant, in the different assemblages and lithoterms.

Gypsum: Frequent.

Hydrochloric test: Positive and negative tests are more or less balanced, with the exception of Core 75 , where the former predominates (in this core, $A / \beta$, $\mathrm{A} / \beta^{\prime}$, and $\mathrm{A} / \mathrm{AP} \beta^{\prime}$ are predominant). Assemblage $\mathrm{T} / \beta$ belongs mainly to calcareous sediments.

\section{Assemblage-Lithofacies Relationships (Table 10)}

Lithoterms B and C correlate, as usual, to $\mathrm{T} / \beta$ and $\mathrm{R} / \mathrm{AP}$, respectively; however, there are many exceptions especially numerous $T / \beta$ in Lithoterm $C$. To be exact, $\mathrm{T} / \beta$ assemblages (which are "regularly" observable in Lithoterm B) are uncommon. With only one exception (780), $T / \beta$ assemblages $(743,765,773,774,775)$ belong to argillo-calcareous sediments, and they are not singularized by any peculiar abundance of $\beta, \pi$, or debris. We are probably faced with poor resedimented material or with impoverished material; it must be emphasized that dissolution is sometimes perceptible.

Similar $T / \beta$ assemblages are sometimes found in Lithocerm $C$. They indicate that the residual deposit has been polluted by a calcareous supply, either diffuse (Samples 738, 737, 731, 728, 762) and resulting in the presence of $\beta$ or $\pi$ or fragments (which have sometimes been subject to dissolution), or else concentrated by a selective enrichment of laminations (e.g., 776 enriched in $\beta, \pi$, mica, and plant debris). We find that assemblages AP are frequently absent (they may have been diluted by the material supplied). In some other cases, the $\mathrm{T} / \beta$ assemblages concerned reveal very low quantities of AP and $\beta$, consequently it could actually correspond to an $\mathrm{A} / \mathrm{AP} \beta$ assemblage if studied under better conditions (picking, sampling).

Some of the R/AP assemblages which are "regularly" observed in Lithoterm C, probably correspond to typical decarbonated residual deposits underneath the CCD (Samples 745, 747, 760, 783, yielding, of course, an A/AP' assemblage). For the rest (736, 741, $755,761,767,768,787,790)$, some pollution can be detected in various ways, depending on the case $(\beta, \pi$, debris, calcareous grains, solution marks). Lastly, one

TABLE 10

Distribution of Assemblages According to the Different Lithoterms in Cores 78 to 74 of Hole 398D

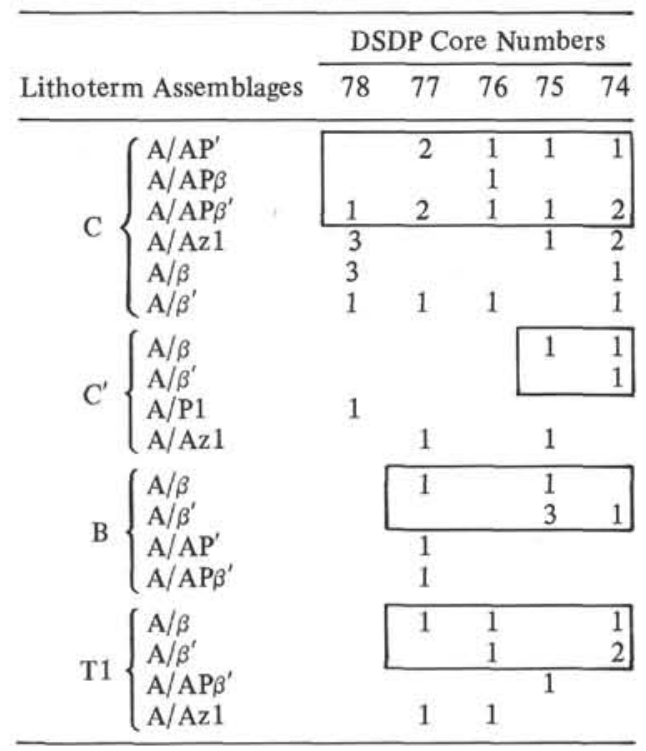


sample (760) corresponds to mixed (Lithoterms C and B) laminations, probably in a slump structure.

Similarly R/AP assemblages are sometimes found in Lithotherm B; they correspond either (753) to a mixed (C and B) sediment or (746) to a swept-away piece of Lithoterm C.

We now have to take into account the more-orless azoic assemblage and Lithoterm $\mathrm{C}^{\prime}$ and Tl. Note that only $\mathrm{A} / \mathrm{Azl}$ has been frequently observed in three categories of sediment: (1) mainly in Lithoterm C and probably in a typical residual deposit $(733,735,764$, 784, 791, 829); (2) then in Lithoterm Tl at the base of a sequence or in a debris flow $(752,757)$; and lastly in Lithoterm $\mathrm{C}^{\prime}$ or sandy laminations with calcareous grains $(749,770)$. On other hand, $\mathrm{A} / \mathrm{Pl}$ is observed only once in Lithoterm $\mathrm{C}^{\prime}$, probably a slump (734).

If we compare Lithoterm $\mathrm{C}^{\prime}$ and $\mathrm{T}$, it appears that they may chiefly contain the same varied assemblages (i.e., $\mathrm{A} / \beta, \mathrm{A} / \beta^{\prime}$, and $\mathrm{A} / \mathrm{Azl}$ ) and consequently they cannot be differentiated according to this criterion, although they are fundamentally different as to their origin (laminations or turbidity, respectively). The similarity of their assemblages conveys the identity of the origin of their material.

\section{Sub-Unit IVb: From Cores 73 to 71}

This short sub-unit corresponds to a more advanced stage in the progressive installation of a pelagic calcareous regime. $T / \beta$ predominates, as well as the positive hydrochloric test. Thus, for the majority of the samples, we are progressively going back to the conditions which prevailed in the lowest Unit I at Site 398. The discriminations between $\mathrm{AP}$ and $\beta$ is losing its meaning; socalled $\mathrm{A} / \mathrm{AP} \beta$ or $\mathrm{A} / \mathrm{AP} \beta^{\prime}$ assemblages mean that $\mathrm{AP}$ predominates quantitatively in the overall assemblage, which we will conversely call $\mathrm{A} / \beta$ or $\mathrm{A} / \beta^{\prime}$ if $\beta$ predominates. Nevertheless, rare typical decarbonated residual deposits still subsist.

The lithologic sequence of reference is the same as below.

\section{Data Analysis}

\section{Organogenic Components}

\section{$\alpha$ Microfauna}

Transported benthos: Rarely abundant (in the lower sequential interval of turbiditic supply or mud flows); but it is also rarely absent (A/APl or A/Azl in various lithoterms, mainly in the residual deposits still present in Lithoterm $C^{\prime}$ ). The amount of $\beta$ in the now uncommon assemblages $\mathrm{A} / \mathrm{AP} \beta$ or $\mathrm{A} / \mathrm{AP} \beta^{\prime}$ is always very small, insofar as we are authorized (as noted above) to distinguish them as still polluted residual assemblages. Qualitatively, the samples here contain the typical association of the usual argillaceous or marly sediments of the "Gault" or Albian.

Residual benthos: If still distinguishable, it is rare and poor.

Plankton: Present in 50 per cent of the samples, always in $A / \beta$, generally uncommon, with the exception of three samples in Lithoterm $\mathrm{Tl}$ (mud flow, samples
$805,806)$ or C ' (829). The group of "large" planktonics develops again here, more intensely than in the upper Aptian, and it will soon give rise to the prolific and characteristic Albian population.

Radiolarians: Always present and generally abundant; recrystallized skeletons are observed in some planktonic-rich samples in Lithoterm $\mathrm{Tl}$.

Dissolution: Perceptible in several samples.

$\beta$ Macrofauna: Organic debris very rare, in only three samples with $\mathrm{A} / \beta^{\prime}$ assemblages and belonging either to a coarse Lithoterm 5 (794) or to laminated C' $(809,818)$. Fish remains and spicules are frequent. There are some unidentifiable ammonites.

$\gamma$ Plant debris: Very sporadic and vanishing upwards.

\section{Inorganic Components}

Clasticity: Quartz generally uncommon and lessening upward, with the exception of four highly clastic samples belonging to Lithoterm $C^{\prime}(810,807)$ or S (794), and probably to a typical residual Lithoterm C (838). Abundant mica occurs in only one sample (826), belonging to a very polluted lithoterm with a great quantity of plant debris.

Glauconite: Absent.

Pyrite: Relatively frequent, particularly in the samples with $\mathrm{A} / \beta$ or $\mathrm{A} / \beta^{\prime}$; rarely abundant.

Gypsum: Abundant, but sporadically observed.

Hydrochloric test: The sediment is calcareous, with the exception of some samples belonging to typical residual Lithoterm $C$. Samples with $T / \beta$ are always calcareous.

\section{Assemblage-Lithofacies Relationships (Table 11)}

$\mathrm{R} / \mathrm{AP}$ or $\mathrm{T} / \beta$ assemblages correlate well with Lithoterm C or Lithoterms $C^{\prime}, \mathrm{B}, \mathrm{Tl}$, and $\mathrm{S}$ (respectively). Thus, R/AP-Lithoterm $C$ and $T / \beta$-Lithoterm B correlations are still found as usual, and we again note the similarity of $\mathrm{C}^{\prime}$ and $\mathrm{Tl}$, as was pointed out for the preceding sub-unit.

As said before, samples which may still represent a decarbonated residual deposit are now very few (i.e., 6 to $7 ; 3$ of which have already been slightly polluted). They typically contain $\mathrm{A} / \mathrm{AP}^{\prime}$ or $\mathrm{A} / \mathrm{Azl}$ assemblages, or $\mathrm{A} / \mathrm{AP} \beta^{\prime}$ when polluted. As in the foregoing unit, $\mathrm{A} / \mathrm{Azl}$ is observed in all kinds of sediments; $\mathrm{A} / \mathrm{Pl}$ is found in Lithoterm $C^{\prime}$.

Generally speaking, we must again emphasize the extensive homogenization which affects the majority of the samples taken and which is caused by the generalization of a calcareous type of sediments.

\section{Unit V: From Cores $\mathbf{7 0}$ to $\mathbf{5 7}$}

This last unit, with a large succession of cores, corresponds to the final stage which ends the evolution of the sedimentary regime we have been following approximately since Core 87 (Sub-unit IIIb). The result consists in a relatively thin, calcareous or chalky pelagic series, at least for a large share of the samples, generally with a prolific planktonic association. Another aspect consists in less lithologic diversity (less important terrigenous 
TABLE 11

Distribution of Assemblages According to the Different Lithoterms in Cores 73 to 71 of Hole 398D

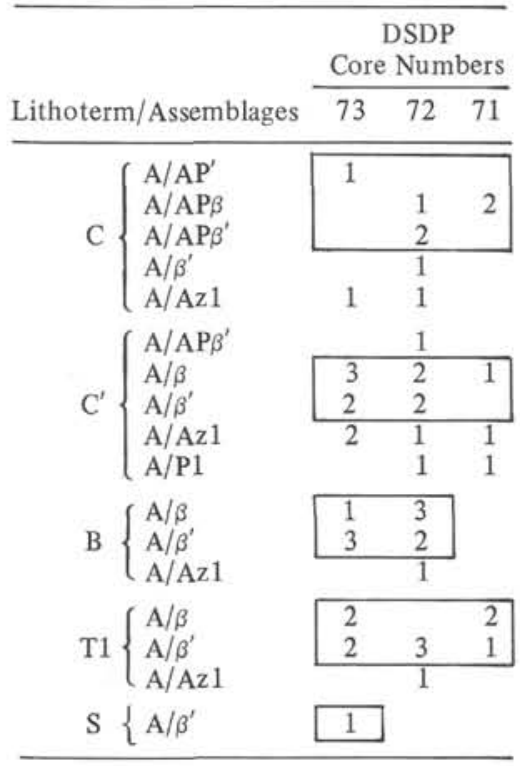

supply), with only two main distinguishable lithofacies, and third lithoterm which corresponds to a laminated texture and probably a mixing of the other two main facies (Figure 6).

\section{Data Analysis}

\section{Organogenic Components}

\section{$\alpha$ Microfauna}

Benthos: Quantitatively very variable, but very frequently abundant, the association is qualitatively as usual in these upper Albian-Vraconian levels. However, $\beta$ is sometimes absent, as will be seen later.

Residual benthos: In five samples in Cores 70 to 62 , only "residual" arenaceous foraminifers are observed. Since this feature coincides with others (such as lithoterm, color, hydrochloric test) which would previously have determined hemipelagic facies (Lithoterm C), we must examine their meaning in greater detail (see below).

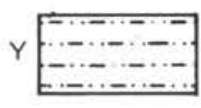

mudstone to calcareous mudstone (nannofossils?)

homogeneous to faintly laminated

generally unburrowed, not expanding

dark gray, greenish black

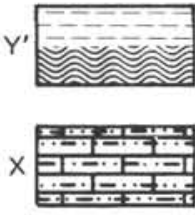

banded or laminated texture intermediary between $Y$ and $X$ or mixed grayish black, dark gray, olive gray

calcareous mudstone to marly nannofossil-chalk faintly laminated or mottled more-or-less intensively burrowed expanding, splintered texture greenish gray, bluish gray

Figure 6. Lithologic sequence of reference for Cores 70 to 57 of Hole $398 D$.
Plankton: One of the main characteristics for this unit consists of pelagic-rich $\mathrm{T} / \beta$ or $\mathrm{A} / \mathrm{P}$ assemblages. However, plankton is frequently missing, which is a surprising feature; it generally occurs in laminated samples where benthos may remain abundant. Otherwise, this lack of plankton coincides with samples which seem to belong to hemipelagic facies as noted above. Lastly, some plankton-rich samples are devoid of benthos (A/Pl, A/P2); they always correspond to laminites, generally with abundant radiolarians.

Radiolarians: Often abundant and diverse, with the exception of Cores 59 and 58 which, on the contrary, contain conspicuously numerous samples devoid of radiolarians. Concerning these last cores, we note that the samples come from laminations where plankton and sometimes benthos or quartz are concentrated. Samples with calcitized radiolarians are very few and scattered, but they suddenly become numerous and predominate in the upper two cores.

Dissolution: Perceptible in several samples, mainly when observation is made with high magnifications.

$\beta$ Macrofauna: Organic debris are very rare, and they have been observed in a few samples which probably correspond to otherwise enriched laminations (plankton, radiolarians, quartz). Fish remains are almost permanent and often abundant. Spicules are rare with the exception of Cores 63 to 60 .

$\gamma$ Plant debris: Rarely present, only in laminated samples.

\section{Inorganic Components}

Clasticity: Weak to nonexistent until Core 61; from Core 60 upwards, numerous quartz-rich samples occur in connection with $T / \beta$ assemblages.

Glauconite: Very rare (with $T / \beta$ in Core 63).

Pyrite: Frequent, often abundant, lessening upwards and almost disappearing in the upper core. This feature seems to correspond to the reverse evolution of recrystallized radiolarians.

Gypsum: Rare, and only in the lower cores.

Hydrochloric test: Positive test predominates. Nevertheless, fairly numerous samples with $\mathrm{A} / \mathrm{AP}^{\prime}, \mathrm{A} / \mathrm{Azl}$, or $\mathrm{A} / \mathrm{Pl}$ assemblages correspond to a negative test.

\section{Assemblage-Lithofacies Relationships}

Examination of individual samples has not been made; this would necessitate again working directly on the original core material.

The data on hand do not enable the problem of the sedimentary context to be solved. The general trend of evolution of the sediments above Core 87 clearly leds to an increasingly calcareous deposit, with increasingly calcareous foraminifers. Nevertheless, scattered samples still occur which, according to certain characteristics, we should have assigned to the carbonate-depleted hemipelagic facies in the underlying units. Thus, we are faced with an antinomy, depending on whether we take into account the preservation of a large quantity of calcareous material, or the persistence of residual deposits. In this way, we are faced with the question of the mutual position of the basin floor and the CCD. 
If we assume that the sedimentary evolution reached its final stage with the installation of a true pelagic regime, this would account for the presence of luxuriant associations of planktonic foraminifers; on the contrary, it cannot be explained how carbonate-depleted sediments with a residual fauna persist, even sporadically.

Conversely, if we accept that the same bathyal or abyssal regime persists during Unit $\mathrm{V}$, it must be assumed that at least a portion, and sometimes a voluminous quantity, of the calcareous material supplied has been preserved; on the contrary, this would account for the presence of these hemipelagic deposits with residual microfauna.

In this way, we note that a portion of the samples taken from Lithoterm Y (i.e., the equivalent of $\mathrm{C}$ previously) yields some but very few typical residual assemblages (i.e., five samples contain $\mathrm{A} / \mathrm{AP}^{\prime}$ assemblages, to which we can add six more samples yielding A/Azl assemblages all from a non-calcareous sediment). Another five to six non-calcareous samples with A/Azl could probably be added, but their corresponding lithoterm was not appropriately determined on shipboard.

The other samples taken from Lithoterm Y are calcareous or argillo-calcareous and generally contain $\mathrm{A} / \beta$ or $\mathrm{A} / \beta^{\prime}$ assemblages (plus one $\mathrm{A} / \mathrm{AP} \beta$ and three $\mathrm{A} / \mathrm{Pl}$ ). Of course, owing to the nature of the sediments, they can be interpreted in this case as being polluted; however, we would have to explain why AP are very rare (Core 65) and generally missing (Cores 61 to 57) possibly "diluted"?

Thus, this crucial problem needs more investigation or sampling to improve our understanding of the sediment itself, and to ascertain that the so-called R/AP assemblages here are really the equivalent of the R/AP which were typically observed in undeniable residual deposits. Moreover, data provided by other micropaleontological or mineralogical techniques must also be taken into consideration.

Lastly, we can note that some general stratigraphic features perhaps advance a decisive although indirect argument in favor of the second interpretation, at least for the uppermost part of the series. Reworked species, the short duration of the lower and middle Cenomanian, and the lack of a continuous series of Cenomanian planktonic associations are geologic features which would not fit very well with the opposite hypothesis of a quiet calcareous pelagic sedimentation. But it is correct to say, conversely, that such a regular stratigraphic succession (as we observed for the upper Albian and Vraconian) is not easy to imagine in a continuously turbiditic or slumping context. In summary, at least some implications of the alternative under consideration still remain open. At present, either observations or the general geological setting favor the concept of a still carbonatedepleted sedimentation, but one that is richly supplied with calcareous turbiditic material.

\section{REFERENCES}

Antonova, Z. A., Shmygina, T. A., Gnedina, A. G., and Kalugina, O. M. 1964. Foraminifères du Néocomien et de l'Aptien entre Pchekha et Ubin. V.N.I.I., Krasnodar fil., Trudy, v. 12, p. 3-72.

Arrhenius, G., 1963. Pelagic sediments. In Hill, M. N. (Ed.), The sea: New York and London (Interscience), v. 3, p. 655-727.
Bartenstein, H., 1974. Upper Jurassic-Lower Cretaceous primitive arenaceous foraminifera from DSDP Sites 259 and 261, Eastern Indian Ocean. In Veevers, J. J., Heirtzler, J. R., et al., Initial Reports of the Deep Sea Drilling Project, v. 27: Washington (U.S. Government Printing Office), p. 683-695.

Bartlett, G. A. and Smith, L., 1971. Mesozoic and Cenozoic history of the Grand Banks of Newfoundland, Canadian J. Earth. Sci., v. 8, p. 65-84.

Berger, W. H., 1972. Deep sea carbonates: dissolution facies and age-depth constancy, Nature, v. 236, p. 392-395.

Berger, W. H. and Winterer, E. L., 1974. Plate stratigraphy and the fluctuating carbonate line, Intern. Assoc. Sediment., Spec. Publ. No. 1, p. 11-48.

Brouwer, J., 1965. Agglutinated Foraminiferal faunas from some turbiditic sequences, I and II, Kon. Nederl. Akad. Wet., Proc., ser B, v. 68, p. 309-318, 319-334.

Chevalier, J., 1961. Quelques nouvelles espèces de foraminifères dans le Cretacé inférieur méditerranéen, Rev. Micropaleontol., v. 4, p. 30-36.

Dailey, D. H., 1970. Some new Cretaceous foraminifera from the Budden Canyon formation, northwestern Sacramento Valley, California, Contrib. Cushman Found. Foram. Res., v. 21, p. 100-111.

Guillaume, S. and Sigal, J., 1965. Le Stratotype du Barrémien. II. Les Foraminifères. In Colloq. Crétacé inférieur, Lyon, Sept. 1963, Bur. Rech. Géol. Min., Mém. 34, p. 117-129.

Hart, M. B., 1976. The mid-Cretaceous succession of Orphan Knoll (Northwest Atlantic): micropaleontology and palaeo-oceanographic implications, Canadian J. Earth Sci., v. 13, p. 1411-1421.

Hart, M. B. and Tarling, D. H., 1974. Cenomanian paleogeography in the North Atlantic and possible mid-Cenomanian eustatic movements and their implication, Paleogeogr., Paleoclim., Paleoecol., v. 15, p. 95-108.

Hesse, R., 1975. Turbiditic and non-turbiditic mudstone of Cretaceous flysch sections of the East Alps and other basins, Sedimentology, v. 22, p. 387-416.

Hiltermann, H., 1968. Neuere palaeontologische Daten zum Flysch-Problem, Erdoel-Erdgas, Z., v. 5, p. 151-157.

1975. Zur Stratigraphie and Mikro fossilführung der Mittelkarpaten, Munster. Forsch. Geol. Palaeont., v. 35, p. 1-50.

Krasheninnikov, V. A., 1974. Upper Cretaceous benthonic agglutinated foraminifera Leg 27. In Veevers, J. J., Heirtzler, J. R., et al., Initial Reports of the Deep Sea Drilling Project, v. 27: Washington (U.S. Government Printing Office), p. 631-661.

Ksazkiewicz, M., 1961. Life conditions in Flysch basins, Ann. Soc. Géol. Pologne, v. 31, p. 3-20.

Le Calves, Y., 1956. Les foraminifères du Pliocène de la Corse, Bull. Soc. Géol. France, n. s., v. 6, p. 583-595.

Longoria, J. F., 1974. Stratigraphic, morphologic and taxonomic studies of Aptian planktonic foraminifera, Rev. Esp. Microp., nùm. extraord., p. 1-107.

Maync, W., 1972. Lower Cretaceous foraminiferal fauna from Goeringe Bank, eastern North Atlantic. In Ryan, W. B. F., Hsü, K. J., et al., Initial Reports of the Deep Sea Drilling Project, v. 13: Washington (U.S. Government Printing Office), p. 1075-1111.

Moullade, M., 1966. Etude stratigraphique et micropaléontologique de Crétacé inférieur de la "fosse vocontienne", Docum. Labor. Géol. Fac. Sci. Lyon, no. 15, p. 1-369.

Neagu, T., 1975. Monographie de la faune des foraminifères éocrétacés du couloir de Dîmbovicioara, de Codlea et des Monts Pertsani (couches de Carhaga), Mém. Inst. géol. et géophys., Bucharest, v. 25, p. 1-141.

Pflaumann, H., 1967. Zur oekologie des bayerischen Flysches auf Grund der mikrofossilfuehrung, Geol. Rundsch., v. 56, p. 200-227.

Pokorny, V., 1960. Ecologie des associations de foraminifères "arénacés" du flysch, Acad. Sci. S.S.S.R., Vopr. Microp., no. 3, p. 10-16. (Translation J. Sigal, Bur. Rech. Géol. Min., No. 2685-3.)

Pujos-Lamy, A., 1973. Le déplacement des faunes de foraminifères benthiques actuels sur la pente continentale et dans la plaine abyssale du Golfe de Gascogne, Bull. Soc. Géol. France, ser. 7, v. 15, p. 392-400.

Saidova, K. M., 1965a. Sediment stratigraphy and paleogeography of the Pacific Ocean by benthic foraminifera during the Quaternary, Progr. Oceanogr., v. 4 , p. 143-151.

1965b. Distribution of benthic foraminifera in the Pacific, Okeanology, v. 5, p. 99-110.

Sastry, M. V. A. and Sastri, V. V., 1966. Foraminifera from the Utatur stage of the Cretaceous formations of Trichinopoly district, Madras. Rec. Geol. Surv. India, v. 94, p. 277-296.

Sigal, J., 1952. Aperçu sur la micropaléontologie stratigraphique de Crétacé. 20th Congr. Géol. Internat, Alger, Monogr. région, (1), no. 26, p. 1-45. 1966. Contribution à une monographie des Rosalines. 1. Le genre Ticinella Reichel, source des Rotalipores, Eclog. Geol. Helv. v. 59, p. 185-217.

Sliter, W. V., 1975. Foraminiferal life and residue assemblage from Cretaceous slope deposits, Geol. Soc. Am. Bull., v. 86, p. 897-906.

Sliter, W. V., Bé A., W. H., and Berger, W. H., 1975. Dissolution of deep-sea carbonates, Cushman Found. Foram. Res., Spec. Publ. 13, p. 1-159.

Stainforth, R. M., 1952. Ecology of arenaceous foraminifera, Micropaleontologist, v. 6, p. $42-44$.

van Stuijvenberg, J., Morel, R., and Jan du Chêne, R., 1976. Contribution à l'étude du Flysch de la région des Fayaux (Préalpes externes vaudoises), Eclog. Geol. Helv., v. 69, p. 309-326.

Thunnel, R. C., 1976. Optimum indices of calcium carbonates dissolution in deep-sea sediment, Geology, v. 4, p. 525-528. 
Vasicek, M., 1947. Remarks on the microbiostratigraphy of the Magura Flysch in Moravia, Vestn. Statn. Geol. Ustav. Czechoslov, v, 22, p. 235-256.

Veevers, J. J., 1977. Paleobathymetry of the crest of spreading ridges related to the age of the Ocean basins, Earth Planet. Sci. Lett., v. 34, p. 100-106.

Wonders, A. A. H., 1975. Cretaceous planktonic foraminifera of the Planomalina buxtorfi group from El Burrueco, Southern Spain, Kon. Nederl. Akad. Wet., Proc., ser. B, v. 78, p. 83-93.

\section{ADDITIONAL SELECTED REFERENCES}

Antonova, Z. A., Baidova, L. A., Kalugina, O. M., and Shmygina, T. A., 1974. La zonation des dépôts du Crétacé inférieur du Caucase NW d'après l'étude des foraminiféres, Soviet Geol., no. 7, p. 97-111.

Aubert, J. and Bartenstein, H., 1976. Lenticulina (L.) nodosa, additional observations in the worldwide Lower Cretaceous, Bull. Centre Rech., Pau-SNPA, p. 1-33.

Bartenstein, H., 1976a. Foraminiferal zonation of the Lower Cretaceous in North West Germany and Trinidad, West Indies, N. Jb. Geol. Pal., Mh., v. 3, p. 187-192.

1976b. Practical applicability of a zonation with benthonic foraminifera in the worldwide Lower Cretaceous, Geol. Mijnb., v. 55, p. 83-86. 1976c. Micropaleontological investigations. Benthonic index, foraminifera in the Lower Cretaceous of the Northern Hemisphere between East Canada and northwest Germany, Erdol Kohle, v, 29, p. 254-256.

1977. Stratigraphic parallelization of the Lower Cretaceous in the Northern Hemisphere, Newslett. Stratigr., v. 6, p. 30-41.

Bartenstein, H., Bettenstaedt, F., and Kovatcheva, T., 1971. Foraminiferen des bulgarischen Barreme, N. Jb. Geol. Pal., Abh., v. 139, p. 125-162.

Basov, V. A., Kaplan, M. E., Judovny, E. G., and N. V. Sharovskaya, 1975. Assemblages de foraminifères de divers environnéments faciologiques du Jurassique et du Néocomien du bassin marin Yenisei-Khatanga, Acad. Sci. SSSR, Siber. branch, Geol. a. Geoph., no. 3, p. 3-9.

Chevalier, J., 1960. Contribution à l'étude stratigraphique et micropaléontologique du Crétacé inférieur du Languedoc et de la Provence, Dipl. Etud. Supét., Paris, p. 1-151.

Damotte, R. and Magniez-Jannin, F., 1973. Ostracodes et foraminifères de l'Aptien inférieur du sondage du Bois du Perchois (Aube), Bull. Inform. Géol. Bass, Paris, no. 36, p. 3-48.

Dupeuble, P. A., Réhault, J. P., Auxiétre, J. L., Dunand, J. P., and Pastouret, L., 1976. Résultats de dragages et essai de stratigraphie des bancs de Galice et des Montagnes de Porto et de Vigo (Marge occidentale ibérique), Marine Geol., v. 22, p. 37-49.

Flandrin, J., Moullade, M., and Porthault, B., 1962. Microfossils caractéristiques de Crétacé inférieur vocontien, Rev. Micropaléontol., v. 4, p. 211-228.

Fletcher, B. N., 1975. The distribution of Lower Cretaceous (BerriasianBarremian) foraminifera in the Speeton Clay of Yorkshire, England. In Casey, R. and Rawson, P. F. (Eds.), The Boreal Lower Cretaceous, p. 161-168.

Geroch, S., 1959. Stratigraphic significance of arenaceous foraminifera in the Carpathian Flysch, Pal. Zeits., v. 33, p. 113-122.

1966. Lower Cretaceous small foraminifera of the Silesian series, Polish Carpathians, Ann. Soc. Geol. Pologne, v. 36, p. 413-480.

Gonzalez-Donoso, J. M., Linares, D., and Oloriz, F., 1974. Sobre la presencia de materiales de edad Aptense en el sector de Campillo de Arenas (Zona subbética, provincia de Jaen), Cuad. Geol., v. 5, p. 89-99.

Gorbachik, T. N., 1971. Les foraminifères due Crétacé inférieur de Crimée, Acad. Sci. SSSR, Vopr. Microp., v. 14, p. 125-139, 211-216.

Gorbachik, T. N. and Kretchmar, V., 1969. Subdivisions des dépôts Aptiens et Albiens de Crimée d'aprés les foraminifères plactoniques, Vestn. Univ. Moscow, no. 3, p. 46-56.

Gradstein, F. M., Williams, G. L., Jenkins, W. A. M., and Ascoli, P., 1975. Mesozoic and Cenozoic stratigraphy of the Atlantic continental margin, Eastern Canada Soc. Petrol. Geol., Mem. 4, p. 103-131.

Grégoire, C., 1966. On organic remains in shells of Paleozoic and Mesozoic Cephalopods (Nautiloids and Ammonoids), Bull. Inst. Roy. Sci. Nat. Belgique, v. 42, p. 1-36. (See also Voss-Foucart, 1971.)

Grün, W., 1969. Mikrofauna vom Flysch im Hagenbach Tal (Wienerwald), Oesterreich. Ann. Soc. Géol. Pologne, v. 39, p. 305-334.

Grün, W., Kittler, G., Lauer, G., Papp, A., and Schnabel, W., 1972. Studien in der Unterkreide des Wienerwaldes (Arbeitsgruppe Wienerwaldflysch), $J b$. Geol. B.-A., v. 115 , p. 103-186.

Hanzlikova, E., 1966. Die foraminiferen der Lothy-Schichten, Acta Musei Moraviae, v. 51, p. 95-132.

Hart, M. B., 1973. A correlation of the macrofaunal and microfaunal zonations of the Gault Clay in Southeast England. In Casey, R. and Rawson, P. F. (Eds.), The Boreal Lower Cretaceous, p. 267-288.

Hermes, J. J., 1966. Lower Cretaceous planktonic foraminifera from the Subbetic of Southern Spain, Geol. Mijnb., v. 45, p. 157-164.

1969. Late Albian foraminifera from the Subbetic of Southern Spain, Geol. Mijnb., v. 48, p. 35-66.
Hesse, R. and Butt, A., 1976. Paleobathymetry of Cretaceous turbidite basins of the East Alps relative to the calcite compensation level, J. Geol., v, 34, p. $505-533$.

Ion-Sandulescu, J., 1975. Microbiostratigraphie, associations et zones à Foraminifères due Crétacé du Flysch externe des Carpates orientales (Roumanie), Rev. Esp. Microp., v. 7, p. 99-111.

Ksazkiewicz, M., 1976. La profondeur du bassin du flysch carpathique, Bull. Soc. Géol. France, sér. 7, v. 18, p. 191-196.

Kuenen, P. H., 1968. Turbidity currents and organisms, Eclog. Geol. Helv,, v. 61 , p. $525-544$.

Kuhry, B., 1971. Lower Cretaceous planktonic foraminifera from the Miravetes, Argos and Repressa formations (SE-Spain), Rev. Esp. Micropaleontol., v. 3, p. 219-237.

Moorkens, T. L., 1976. Paloekologische Bedeutung einiger Vergesellschaftungen von sandschaligen foraminiferen aus dem NW europaeischen Alttertia er und ihre Beziehung zu Muttergesteinen, Compendium 75/76, Erdoel Hohle Z., p. 77-95.

Moullade, M., 1960. Sur quelques foraminifères du Crétacé inférieur des Baronnies (Drôme), Rev. Micropaleontol., v. 3, p. 131-142.

1965. Nouvelles propositions pour l'établissement d'une zonation micropaléontologique de l'Aptien et de l'Albien vocontiens, C. R. Somm. Soc. Géol. France, no. 2, p. 48-49.

, 1974. Zones de foraminifères du Crétacé inférieur mésogèen, $C . R$ Acad. Sci. Paris, v. 278, p. 1813-1816.

Mutti, E. and Richi-Lucchi, F., 1972. Le torbiditi dell'Apennino settentrionale: introduzione all'analisi di facies, Mem. Soc. Geol. Ital., v. 11, p. 161-199.

Neagu, T., 1962. Clavulinoides gaultimus (Morozowa, 1948) dans le Flysch crétacé en Roumanie, Ann. Soc. Géol. Pologne, v. 32, p. 415-426.

1972. The Eo-Cretaceous foraminiferal fauna from the area between the Dolomitza and Prahova valleys (Eastern Carpathians), Rev. Esp. Micropaleontol., v. 4, p. 181-224.

Porthault, B., 1974. Le Crétacé supérieur de la "fosse vocontienne" et des régions limitrophes (France SE). Micropaléontologie, stratigraphie, paléogéographie, Thèse, Fac. Sci. Lyon, p. 1-342.

Ramalho, M. M. et Rey, J., 1975. Etat des connaissances actuelles sur le Jurassique terminal et le Crétacé basal du Portugal, Bur. Rech. Géol. Min., Mém. 86, Colloq. Limite Jurass-Crét., p. 265-273.

Rey, J., 1972. Recherches géologiques sur le Crétacé inférieur de l'Estramadura (Portugal), Thèse, Fac. Sci., Toulouse, p. 1-529.

Rey, J. and Ramalho, M. M., 1974. Le Crétacé inférieur de l'Algarve occidental (Portugal), Comun. Serv. Geol. Port., v. 57, p. 155-181.

Reyment, R. A., 1957. Ueber Farbspuren bei einigen Ammoniten, N. J. Geol. Pal., Mh., p. 343-351.

Ricci-Lucchi, F., 1975. Depositional cycles in two turbidite formations of Northern Apennines (Italy), J. Sediment Petrol., v. 45, p. 3-43.

Sandulescu, J., 1967. Contribution à la connaissance des Foraminifères éocrétacés des Carpates orientales (zones internes), Assoc. Géol. carpatobalk., 7th Congr., Belgrade, Strat., p. 337-344.

Scheibnerova, V., 1974. Aptian-Albian benthonic foraminifera from DSDP Leg 27. Sites 259, 260 and 263, Eastern Indian Ocean. In Veevers, J. J., Heirtzler, J. R., et al., Initial Reports of the Deep Sea Drilling Project, v. 27: Washington (U.S. Government Printing Office), p. 697-741.

Schlanger, S. O. and Jenkyns, H. C., 1976. Cretaceous organic anoxic events: causes and consequences, Geol. Mijnb., v. 55, p. 179-184.

Sigal, J., 1967. Essai sur l'état actuel d'une zonation stratigraphique à l'aide des principales espèces de Rosalines (Foraminifères), C. R. Somm. Soc. Géol. France, no. 2, p. 48-49.

1969. Contribution à une monographie des Rosalines. 2. L'espèce Rotalipora apenninica (O. Renz, 1936). Origine phylétique et taxonomie, Ist Intern. Conf. Plankt. Microfoss. Proc., Geneva, 1967, v. 2, p. 622-639.

1977. Essai de zonation du Crétacé mediterranéen à l'aide des foraminifères planctoniques, Géol. Méditerranéenne, v. IV, p. 49-108.

Smith, L., 1973. Late Mesozoic and Cenozoic of the Sable Island Bank and Grand Banks. In Earth Sci. Symp. on Offshore East Canada, Geol. Surv. Canada, Paper. 71-23, p. 267-283.

Stelck, C. R., 1972. The upper Albian Miliammina manitobensis Zone in northeastern British Columbia, Geol. Assoc. Canada, Spec. Paper 13, p. 253-275

Subbotina, N. N. et al., 1964. Foraminifères des dépôts crétacés et paléogènes de la dépression de Sibérie orientale, V.N.I.G.R.I., Trudy, v. 234, p. 1-456.

Suleimanov, I. S., 1969. La systématique de la famille des Trochamminidae Schwager, 1877 et des Ammodiscidae Reuss, 1862, Doklad. Acad. Sci. Ukr. SSR, No. 6, p. 50-51.

Thiede, J. and van Andel, T. H., 1977. The paleoenvironment of anaerobic sediments in the late Mesozoic South Atlantic Ocean, Earth Planet. Sci. Letl., v. 33 , p. 301-309.

Tsirekidze, L. R., 1976. Microforaminifères des dépôts du Crétacé inférieur de la périphérie S et E du massif de Dzizuls, Vopros. Strat. Paleont. Cret. Gruzii, Tbilisi, Acad. Sci. Gruz., Geol. Inst., Trudy, n. s., v. 50, p. 5-68.

Voss-Foucart, M. F. and Grégoire, C., 1971. Biochemical composition and submicroscopic structure of matrices of nacreous conchioline in fossile Cephalopods (Nautiloids and Ammonoids), Bull. Inst. Roy. Sci. Nat. Belgique, v. 47 , p. 1-42. 
APPENDIX II: Key to Sediment Summary Chart 1A (on microfiche), back pocket.

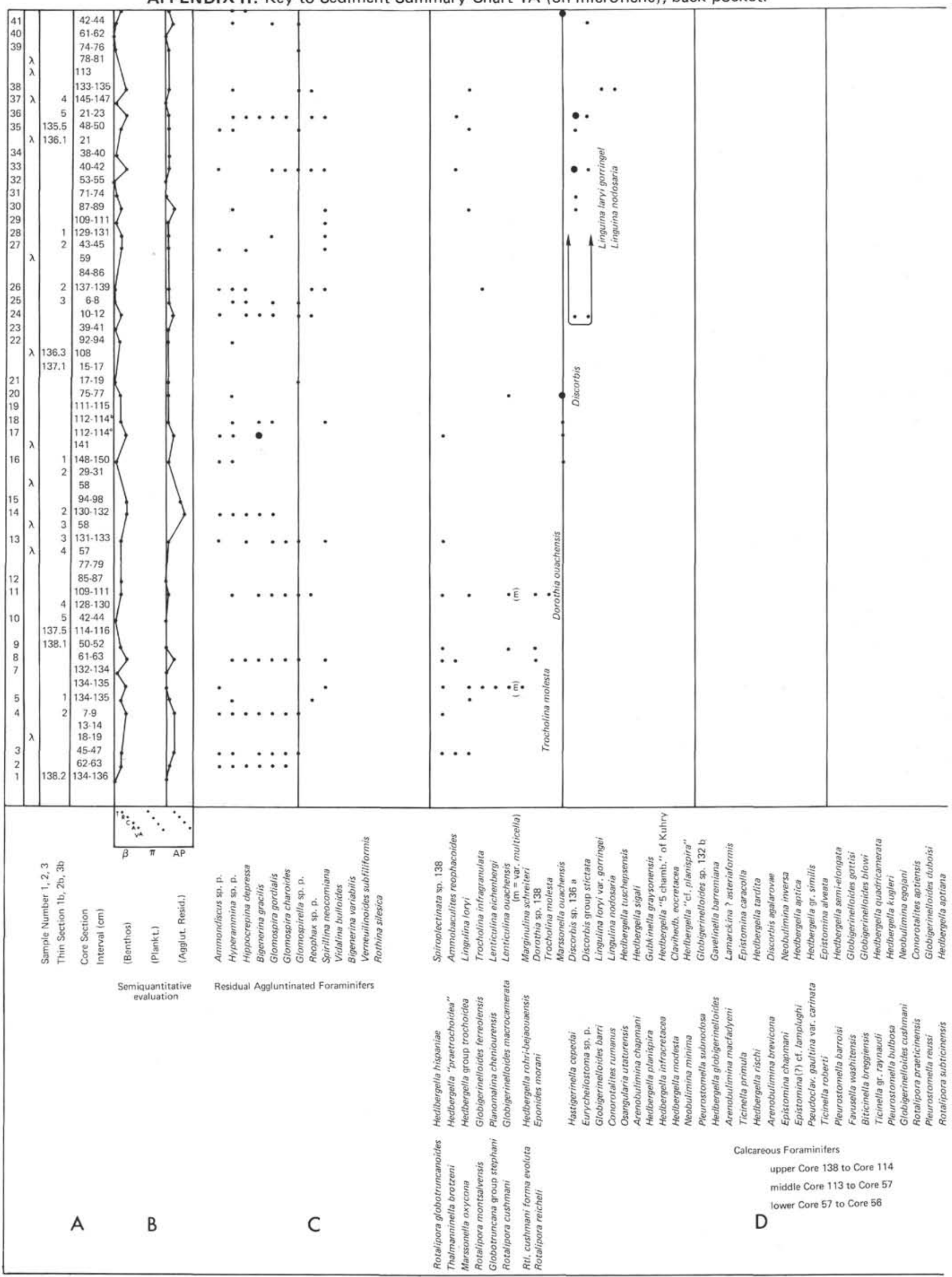




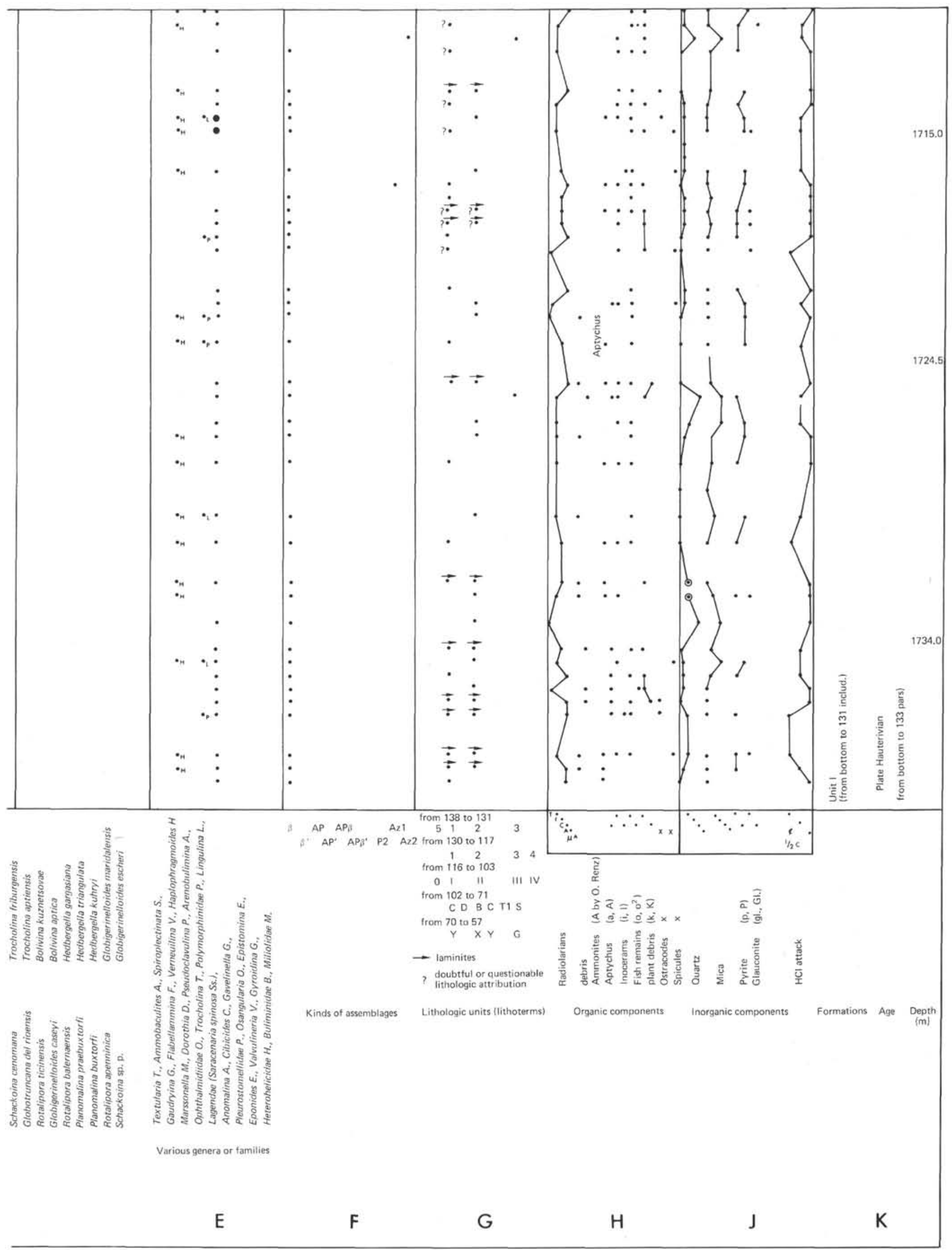




\section{PLATE 1}

Figure 1 Ammodiscus sp., $110 \times$. Barremian (Sample 130-5, 91-93 cm).

Figure 2 Reophax cf. minutissima Bartenstein and Brand, 1951. $75 \times$. Hauterivian (Sample 137-4, 109-111 $\mathrm{cm})$.

Figure 3 Hyperammina gaultina ten Dam, 1950. $50 \times$. Hauterivian (Sample 134-2, 120-122 cm).

Figure 4 Hyperammina sp. 1 Bartenstein, 1974. $25 \times$. Early Albian (Sample 94-2, 23-25 cm).

Figure 5 Hippocrepina depressa Vasicek, 1947. $75 \times$. Hauterivian (Sample 135-5, 21-23 cm).

Figure 6 Hippocrepina sp.a. $50 \times$. Early Albian (Sample 100-3, 45-47 cm).

Figure 7 Hippocrepina sp.b. $25 \times$. Early Albian (Sample 96-5, 99-101 cm).

Figures 8, 9 Bigenerina gracilis Antonova, 1964. $75 \times$. Hauterivian (Samples 137-2, 130-132 cm and 137-1, $112-114 \mathrm{~cm})$. Microspheric and macrospheric specimens.

Figure 10 Glomospira gordialis (Jones and Parker, 1860). $80 \times$. Early Aptian (Sample 111-4, 57-59 cm).

Figure 11 Glomospira irregularis (Grzybowski, 1897). $80 \times$. Late Aptian (Sample 105-3, 125-127 cm).

Figure 12 Glomospira charoides (Jones and Parker, 1860). $140 \times$. Early Aptian (Sample 111-5, 80-82 cm).

Figure 13 Spirillina neocomiana. Moullade, 1961. $100 \times$. Hauterivian (Sample 138-1, 133-135 cm).

Figure 14 Glomospirella multivoluta (Romanova, 1955). $125 \times$. Hauterivian (Sample 135-1, 70-72 cm).

Figure $15 \quad$ Spiroplectinata sp. $75 \times$. Hauterivian (Sample 138-2, $45-47 \mathrm{~cm}$ ).

Figure 16 Ammobaculites cf. reophacoides Bartenstein, 1952. $70 \times$. Barremian (Sample 130-4, 20-22 cm).

Figure 17 Lingulina loryi (Berthelin, 1880). $75 \times$. Hauterivian (Sample 135-4, 133-135 cm).

Figure 18 Lingulina loryi var. gorringei Maync, 1972. $75 \times$. Hauterivian (Saminelloides escheri [Kaufmann, 1865]). $300 \times$. Late Aptian (Sample 113-3, 32-34 cm).

Figure 19 Trocholina infragranulata Noth, 1951. $200 \times$. Early Aptian (Sample 127-4, 16-18 cm).

Figure 20 Lenticulina eichenbergi Bartenstein and Brand, 1951, $50 \times$. Hauterivian (Sample 138-1, 133-135 c m ).

Figure 21 Marssonella ouachensis Sigal, 1952. $65 \times$. Early Aptian (Sample 120-4, 112-114 cm).

Figure 22 Lenticulina ouachensis Sigal, 1952. $50 \times$. Hauterivian (Sample 138-1, 133-135 cm).

Figure 23 Lenticulina ouachensis var. multicella Bart., Bettenst., and Bolli, 1957. $50 \times$. Hauterivian (Sample $138-1,133-135 \mathrm{~cm})$.

Figure 24 Lenticulina nodosa (Reuss, 1863). $50 \times$. Hauterivian (Sample 138-1, 133-135 cm).

Figures 25, 26 Hedbergella tuschepsensis Antonova, 1964. $300 \times$. Barremian (Sample 133-2, 139-141 cm). Spiral and umbilical views.

Figures 27, 28 Hedbergella sigali Moullade, 1966. $300 \times$. Barremian (Sample 133-2, 139-141 cm). Spiral and umbilical views.

Figure 29 Gubkinella graysonensis (Tappan, 1940). $300 \times$. Barremian (Sample 133-2, 139-141 cm).

Figures 30, 31 Clavihedbergella eocretacea Neagu, 1975. $300 \times$. Barremian (Samples 129-6, 17-19 cm and 129-7, $33-41 \mathrm{~cm})$. Spiral and umbilical views. 


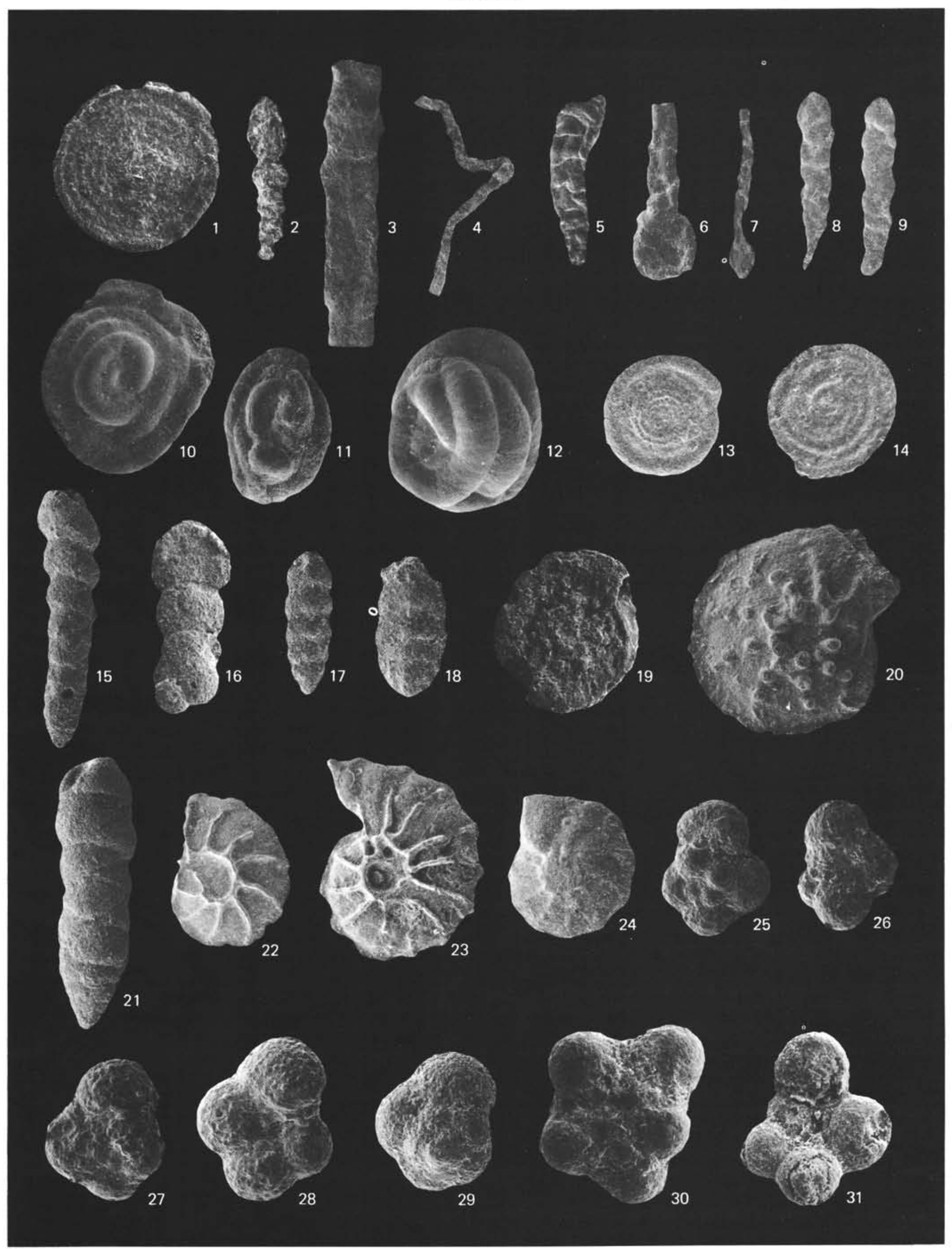




\section{PLATE 2}

Figures 1, 2 Hedbergella aff. planispira auct. $200 \times$. Early Aptian (Sample 127-1, 47-49 cm). Spiral and umbilical views.

Figures 3, 4 Hedbergella ventriosa Antonova, 1964. $200 \times$. Early Aptian (Sample 127-4, 16-18 $\mathrm{cm})$. Spiral and umbilical views.

Figures 5, 6 Gavelinella barremiana Bettenstaedt, 1952. $100 \times$. Barremian (Sample 130-3, 46-48 $\mathrm{cm})$. Umbilical and spiral views.

Figures 7, $8 \quad$ Lamarckina (?) asteriaformis Kuznetsova and Antonova, 1964. $80 \times$ and $100 \times$. Barremian (Sample 129-5, 88-90 cm). Spiral and umbilical views.

Figures 9, 10 Epistomina caracolla (Roemer, 1841). $80 \times$ and $70 \times$. Barremian (Samples 129-6, $22-23 \mathrm{~cm}$ and $129-5,88-90 \mathrm{~cm})$. Spiral and umbilical views.

Figures 11, 12 Hedbergella tardita Agalarova, 1964. $400 \times$. Late Aptian (Sample 108-4, 110-112 $\mathrm{cm})$. Spiral and umbilical views.

Figures 13, 14 Hedbergella aptica (Agalarova, 1951). $250 \times$. Early Aptian (Samples 123-5, 8-10 cm and $122-6,46-48 \mathrm{~cm})$. Spiral and umbilical views.

Figures 15, 16 Hedbergella similis Longoria, 1974. $200 \times$ and $180 \times$. Early Aptian (Samples $123-4,128-130 \mathrm{~cm}$ and $121-1,128-130 \mathrm{~cm})$. Spiral and umbilical views.

Figure 17 Neobulimina inversa Antonova and Gnedina, 1964. $300 \times$. Barremian (Sample $129-7,18-20 \mathrm{~cm})$.

Figure 18 Epistomina alveata Espitalie and Sigal, 1963. $60 \times$. Early Aptian (Sample 122-4, $131-133 \mathrm{~cm})$. Umbilical view.

Figure 19 Hedbergella quadricamerata Antonova, 1964. $400 \times$. Early Aptian (Sample 127-4, $16-18 \mathrm{~cm})$. Spiral view.

Figure 20 Blowiella blowi (Bolli, 1959) or "prae-gottisi." $400 \times$. Early Aptian (Sample 121-6, $5-7 \mathrm{~b} \mathrm{~cm})$.

Figure 21 Globigerinelloides gottisi (Chevalier, 1961). $200 \times$. Early Aptian (Sample 122-6, $46-48 \mathrm{~cm})$.

Figure 22 Neobulimina egojani Antonova, 1964. $150 \times$. Early Aptian (Sample 122-2, 27-29a $\mathrm{cm})$.

Figure 23 Globigerinelloides duboisi (Chevalier, 1961). $200 \times$. Late Aptian (Sample 117-7, $38-40 \mathrm{~cm})$.

Figures 24, 25 Hedbergella aptiana Bartenstein, 1965. $220 \times$ and $200 \times$. Early Aptian (Samples $123-5,8-10 \mathrm{~cm}$ and $123-4,18-20 \mathrm{~cm})$. Spiral and umbilical views.

Figure 26 Trocholina friburgensis Guillaume and Reichel, 1957. $180 \times$. Early Aptian (Sample $124-4,6-8 \mathrm{~cm})$.

Figure 27 Trocholina aptiensis lovtcheva, 1962. 65×. Early Aptian (Sample 121-5, 133-135b $\mathrm{cm})$. 
PLATE 2
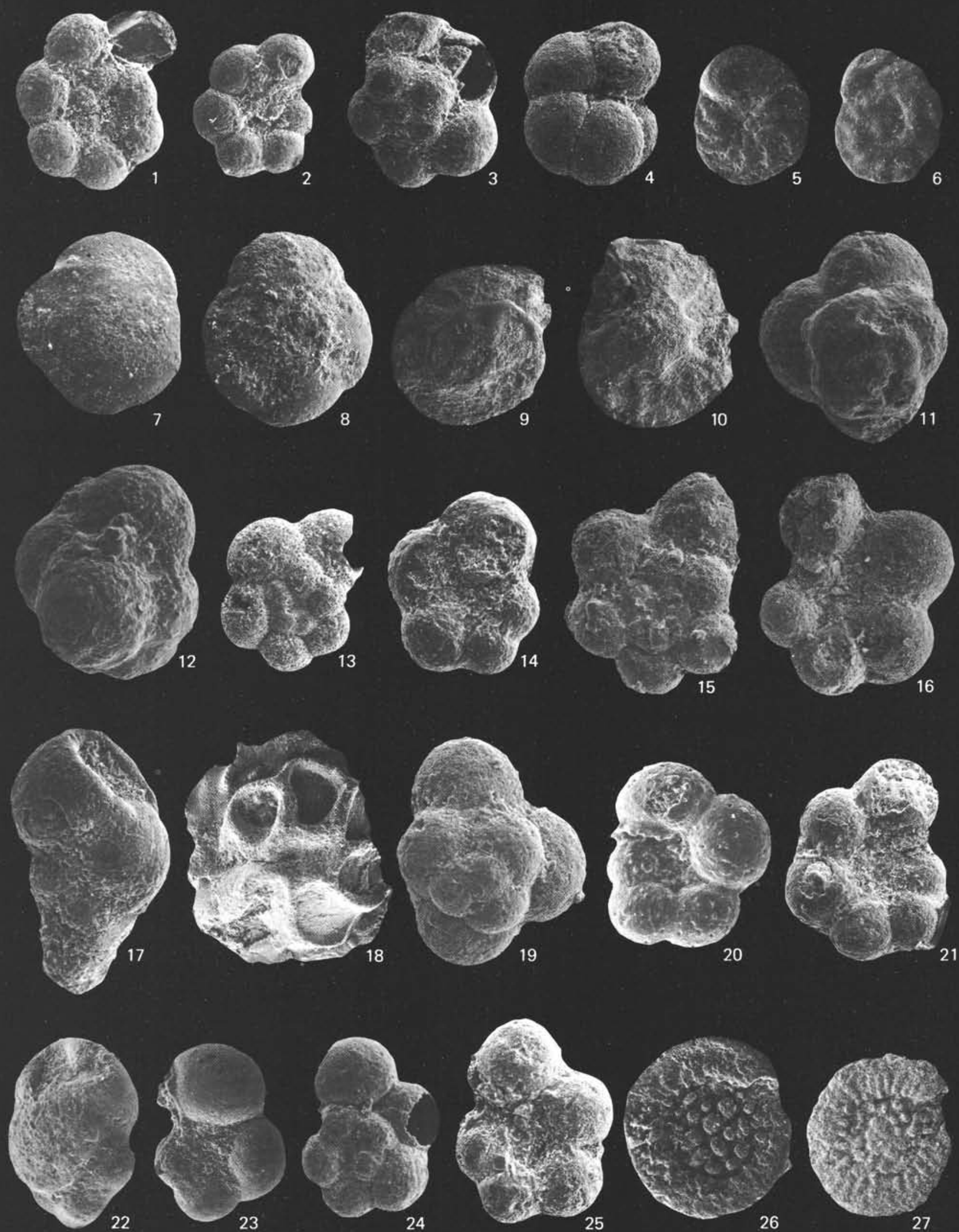


\section{PLATE 3}

Figure 1 “Bolivina” aptica Tajrov, 1961. $150 \times$. Early Aptian (Sample 121-5, 133-135 cm).

Figure 2 “Bolivina” kusnetsovae Antonova, 1964. $200 \times$. Late Aptian (Sample 114-2, 35-37 cm).

Figures 3, 4 Hedbergella gargasiana Moullade, 1961. $400 \times$. Late Aptian (Sample 112-5, 10-12 cm). Spiral and umbilical views.

Figure 5 Bigenerina variabilis (Vasicek, 1947). $70 \times$. Early Albian (Sample 101-6, 63-65 cm).

Figure 6 Verneuilinoides group of subfiliformis Bartenstein, 1952. $90 \times$. Late Aptian (Sample 112-3, 105$107 \mathrm{~cm})$.

Figure 7 Hedbergella triangulata Antonova, 1964. $400 \times$. Late Aptian (Sample 114-5, 12-14 cm). Umbilical view.

Figure $8 \quad$ Globigerinelloides maridalensis (Bolli, 1959). $300 \times$. Late Aptian (Sample 112-3, 32-34 cm).

Figure 9 Globigerinelloides escheri (Kaufmann, 1865). $300 \times$. Late Aptian (Sample 113-3, 32-34 cm).

Figures 10, 11 Hedbergella trochoidea (Gandolfi, 1942). $80 \times$. Late Aptian (Samples 104-4, 12-14 cm and 104-4, $111-113 \mathrm{~cm})$. Spiral and umbilical views.

Figure 12 Globigerinelloides ferreolensis (Moullade, 1961). $100 \times$. Late Aptian (Sample 109-1, 48-50 cm).

Figure 13 Planomalina cheniourensis Sigal, 1952. $80 \times$. Late Aptian (Sample 108-5, 44-46 cm).

Figures 14, 15 “Hedbergella”' aff. Ticinella bejaouaensis Sigal, 1966. $80 \times$. Late Aptian (Sample 104-2, 9-11 cm). Spiral and umbilical views.

Figures 16, 17 Hastigerinelloides cepedai Obregon, 1959. $200 \times$ and $150 \times$. Late Aptian (Samples 104-2, 67-69 cm and $106-3,18-20 \mathrm{~cm})$.

Figure 18 Eurycheilostoma cf. grandstandensis Tappan, 1957. $200 \times$. Late Aptian (Sample 106-2, 83-85 cm).

Figure 19 Eurycheilostoma $\mathrm{cf}$. robinsonae Tappan, 1957. $200 \times$. Late Aptian (Sample 104-4, 12-14 cm).

Figure 20 Globigerinelloides barri (Bolli, Loeblich, and Tappan, 1957). $100 \times$. Late Aptian (Sample 104-2, 9-11 cm). Oblique views.

Figures 21, 22 Osangularia utaturensis Sastry and Sastri, 1966. $100 \times$ and $80 \times$. Late Albian (Sample 62-3, 9-11 $\mathrm{cm}$ ) and Vraconian (Sample 61-2, 56-58 cm). Spiral and umbilical views.

Figures 23, 24 Hedbergella planispira (Tappan, 1940). $300 \times$ and $200 \times$. Middle Albian (Sample 69-3, 25-27 cm) and Late Albian (Sample 68-1, 38-40 cm). Spiral and umbilical views.

Figure 25 Neobulimina cf. minima Antonova, 1964. $250 \times$. Early Albian (Sample 95-4, 36-38 cm).

Figures 26, 27 Hedbergella (? Praeglobotruncana) modesta (Bolli, 1959). $200 \times$. Middle Albian (Sample 71-4, $12-14 \mathrm{~cm})$. Spiral and umbilical views. 

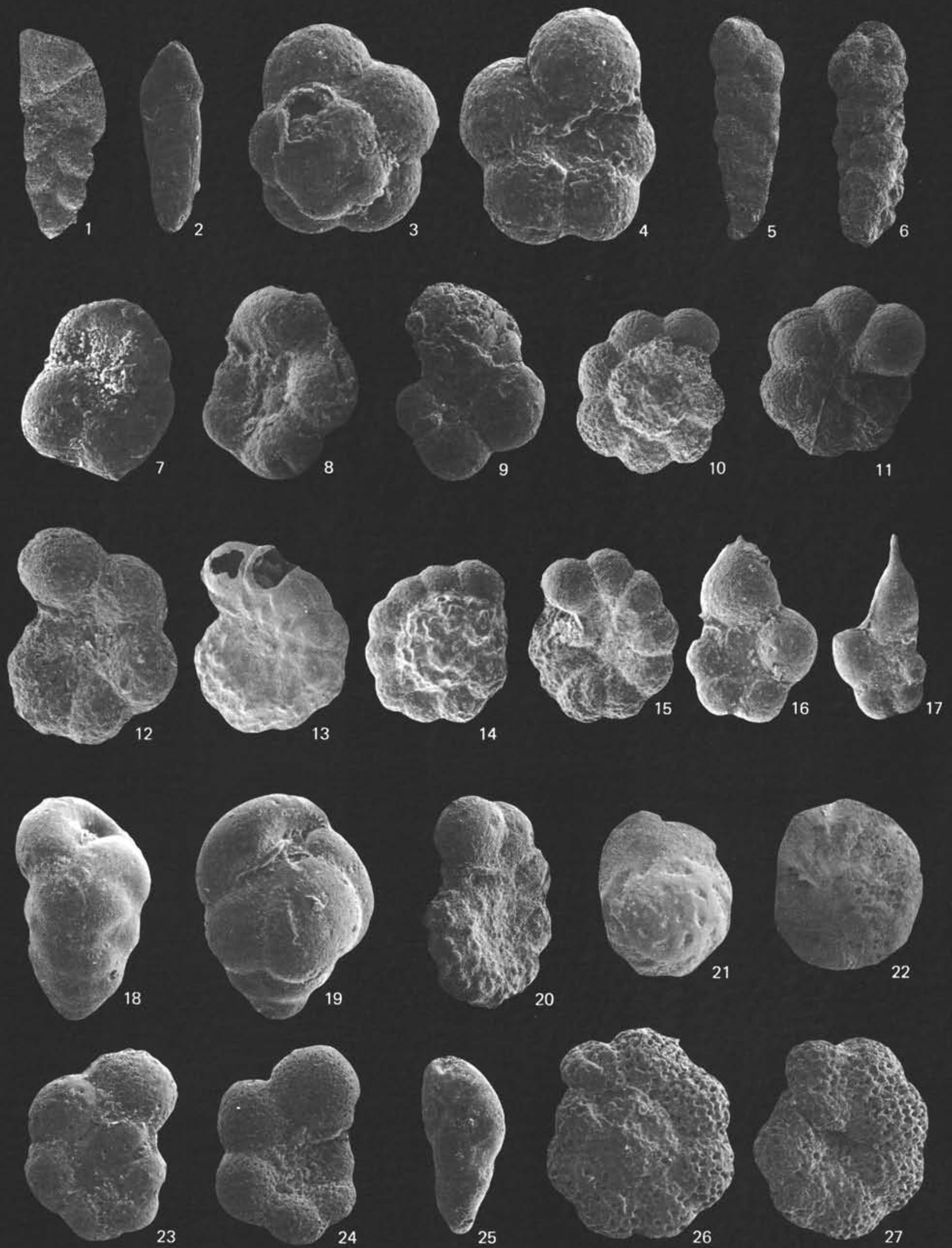


\section{PLATE 4}

Figures 1, 2 Pleurostomella subnodosa Reuss, 1860. $60 \times$. Early Albian (Sample 92-2, 55-57 $\mathrm{cm})$. Microspheric and macrospheric specimens.

Figures 3, 4 Hedbergella globigerinelloides (Subbotina, 1949). $250 \times$ and $300 \times$. Middle Albian (Sample 81-3, 131-133 cm). Spiral and umbilical views.

figures 5, 6 Ticinella primula Luterbacher, 1963. $150 \times$ and $200 \times$. Late Albian (Sample 69-5, $80-85 \mathrm{~cm})$. Spiral and umbilical views.

Figure 7 Pseudoclavulina gaultina var. carinata Neagu, 1962. $40 \times$. Late Albian (Sample $65-5,13-15 \mathrm{~cm})$.

Figure $8 \quad$ Pleurostomella barroisi Berthelin, 1880. $120 \times$. Late Albian (Sample 63, CC)..

Figures 9, 10 Ticinella roberti (Gandolfi, 1942). $70 \times$ and $100 \times$. Late Albian (Sample 65-4, $18-20 \mathrm{~cm})$. Spiral and umbilical views.

Figure 11 Ticinella (Biticinella) breggiensis (Gandolfi, 1942). $100 \times$. Late Albian (Sample $67-3,78-80 \mathrm{~cm})$. Front view.

Figures 12, 13 Pleurostomella (Clarella) bulbosa (ten Dam, 1950). $60 \times$ and $70 \times$. Late Albian (Sample 66, CC). Macrospheric and microspheric specimens.

Figures 14, 15 Rotalipora praeticinensis Sigal, 1966. $100 \times$. Late Albian (samples 66-1, 122-125 cm and $67-3,78-80 \mathrm{~cm})$. Spiral and umbilical views.

Figures 16, 17 Rotalipora (thalmanninella) subticinensis Gandolfi, 1957. $80 \times$. Late Albian (Sample $65-5,135-137 \mathrm{~cm})$. Spiral and umbilical views.

Figure 18 Schackoina cf. cenomana (Schacko, 1897). $300 \times$. Late Albian (Sample 65-5, $135-137 \mathrm{~cm})$. Spiral view.

Figures 19, 20 Rotalipora (Thalmanninella) ticinensis (Gandolfi, 1942). $70 \times$ and $100 \times$. Late Albian (Sample 62-3, 61-63 cm). Spiral and umbilical views.

Figure $21 \quad$ Globigerinelloides caseyi (Bolli, Loeblich and Tappan, 1957). $100 \times$. Late Albian (Sample 63-3, 143-145 cm).

Figures 22, 23 Rotalipora balernaensis Gandolfi, 1957. $80 \times$. Vraconian (Sample 60-2, 6-8 cm). Spiral and umbilical views.

Figures 24, 25 Rotalipora balernaensis forma evoluta. $80 \times$ and $100 \times$. Vraconian (Sample 60-2, 6-8 $\mathrm{cm})$. Spiral and umbilical views.

Figure 26 Planomalina praebuxtorfi Wonders, 1975. $80 \times$. Late Albian (Sample 63-2, 18-20 cm).

Figures 27, 28 Planomalina buxtorfi (Gandolfi, 1942). $50 \times$ and $60 \times$. Vraconian (Sample 59-3, $7-9 \mathrm{~cm})$. Normal and uncoiling specimens.

Figures 29, 30 Rotalipora apenninica (Renz, 1936). $50 \times$ and $60 \times$. Early Cenomanian (Samples $57-1,105-107 \mathrm{~cm}$ and $57-3,17-19 \mathrm{~cm})$. Spiral and umbilical views. 

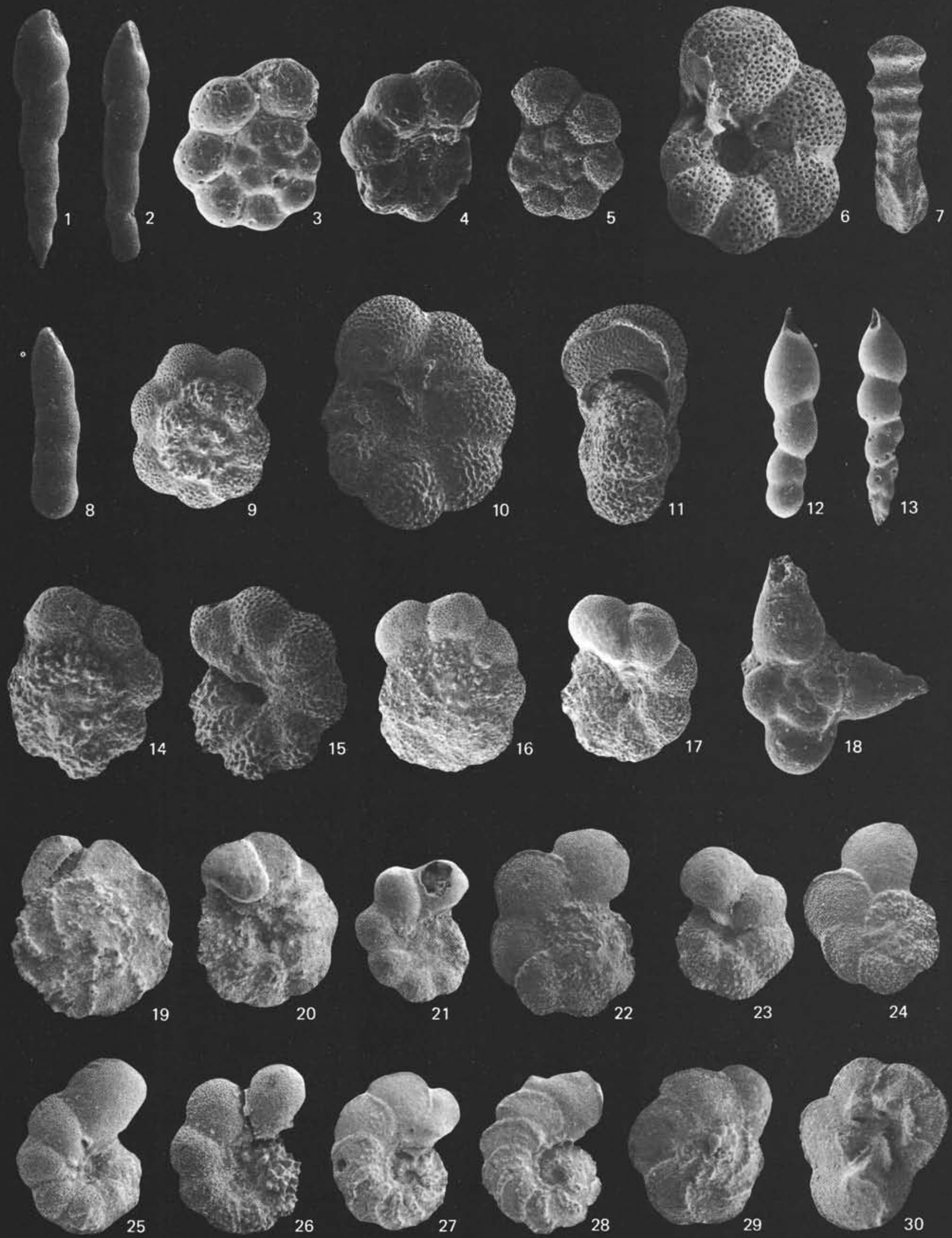


\section{PLATE 5}

Figure 1

Figure 2

Figure 3

Figure 4

Figure 5

Figure 6

Figure 7

Figures 8, 9

Rotalipora globotruncanoides Sigal, 1948. $60 \times$. Early Cenomanian (Samples 57-5, 8-10 cm and $56-5,146-148 \mathrm{~cm})$. Spiral and umbilical views.

Figures 10, 11 Rotalipora (Thalmanninella) brotzeni Sigal, 1948. $100 \times$ and $80 \times$. Early Cenomanian (Sample $56-5,146-148 \mathrm{~cm})$. Spiral and umbilical views.

Figure 12 Marssonella oxycona (Reuss, 1860). $100 \times$. Early Cenomanian (Sample 57-4, 86-88 cm).

Figures 13, 14 Rotalipora montsalvensis Mornod, 1950. $80 \times$ and $90 \times$. Early Cenomanian (Sample 56-6, $105-107 \mathrm{~cm})$. Spiral and umbilical views.

Figures 15, 16 Rotalipora cushmani (Morrow, 1934). $50 \times$. Middle Cenomanian (Sample 56-3, 45-47 cm). Spiral and umbilical views.

Figures 17, 18 Rotalipora reicheli Mornod, 1950. $70 \times$ and $60 \times$. Middle Cenomanian (Sample 56-3, 45-47 $\mathrm{cm})$. Spiral and umbilical views.

Figures 19-25 n.gen., n.sp. (aff. Hedbergella planispira).

19, 20. $200 \times$. Late Albian (Sample 65-5, 135 $137 \mathrm{~cm})$.

21, 22. $200 \times$. Late Albian (Sample 65-5, 133$135 \mathrm{~cm})$.

23. $500 \times$. Detail of specimen Figure 19 .

24, 25. $1000 \times$. Detail of specimen from late Albian (Sample 65-5, 135-137 cm). 

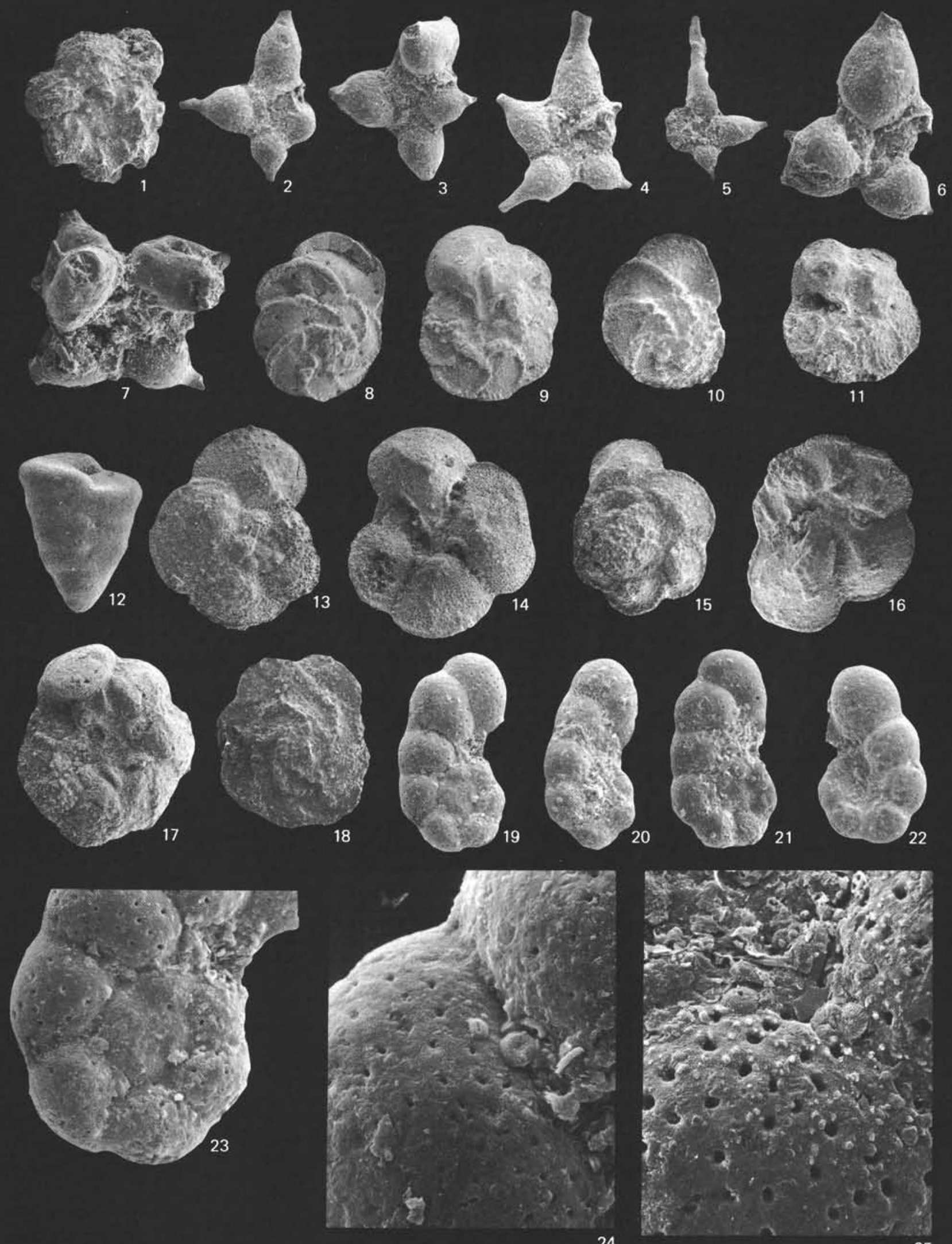


\section{APPENDIX}

\section{Lower Cretaceous Ostracodes}

N. Grekoff ${ }^{1}$ and J, F. Babinot ${ }^{2}$

Ostracodes are poorly represented in both Lower and Upper Cretaceous sediments. Hauterivian to Vraconian series, which were especially investigated, yielded only about 50 specimens from 800 samples (generally no more than one specimen to a sample). They can be attributed to 10 to 12 genera or higher taxa. Additionally, they are generally small and their preservation is poor, with the exception of one or two of the largest ones. Carapaces are closed and, consequently, anatomic criteria are irrelevant to a modern taxonomic determination.

From a systematic point of view, we note that Cytherurinae and small Cytheridae are relatively predominant, and that Monoceratina, Paracypris, Cytherella, and Bairdia are frequent. Only one form which was determined belongs to the specific group Schuleridae jonesiana (Bosquet, 1846).

No precise stratigraphic conclusion can be formulated because the vertical extension of the different genera is too large. Schuleridea jonesiana has been encountered in Europe from the Aptian to the Cenomanian, and agrees with the age given by planktonic foraminifers from Hole 398D.

Paleoecologically two different populations that originated in two paleoenvironments can be distinguished:

1) Small species, which are most numerous in the selected population, with a thin and smooth shell, probably correspond to a deep marine, in-situ association. The genera Cytheropteron and Monoceratina agree with such a hypothesis; it is known that some species of

'(A 14), 140, Route de la Reine, 92100, Boulogne, France.

2 Laboratoire de Géologie, Historique, Université de Marseille, 1 Place Victor Hugo, 13331 Marseille, Cedex 3, France.
Paracypris, Cytherella, Cytherelloidea, and Brachycythere can live at great depths. Their small size and scarcity support this interpretation.

2) By contract, a few specimens (i.e., some highly calcified Cytherella, some punctuate Bairdia, large and well-preserved Schuleridea jonesiana) belong to populations which inhabit shallower or littoral waters on the continental shelf. Thus, they at least have been displaced if not reworked; Table 2 clearly shows that in three instances they come from cores where reworked microfossils (Calpionellids and foraminifers) were found in slumped sediments.

In summary, the following taxa were recognized:

Hauterivian: ?Cytherurinae (Samples 138-1, 133-135 cm)

Bairdia (Sample 135-4, 133-135 cm)

Monoceratina (Samples 135-4, 133-135 cm and $135-3,86-88 \mathrm{~cm})$

Cyprididae (Sample 134-1, 60-62 cm)

Paracypris (Sample 133-3, 105-107 cm)

Barremian: Monoceratina (Sample 130-4, 20-22 cm)

?Paracypris (Samples 126-4, 27-29 $\mathrm{cm}$ and $126-1,113-115 \mathrm{~cm})$

Lower Aptian: Paracypris (Sample 125-4, 49-51 cm)

Cytherella (Samples 125-4, 27-29 $\mathrm{cm}$ and $124-4,6-8 \mathrm{~cm})$

Cytheropteron (Sample 125-2, 8-10 cm)

? Brachycythere (Sample 123-1, 77-79 cm)

Bairdia (punctuate) (Sample 122-2, 27-29 cm)

Cytherelloidea (Sample 121-6, 94-96 cm)

Upper Aptian: Paracypris (Samples 120-4, 112-114 cm and $105-3,57-59 \mathrm{~cm})$

Cytherella (Sample 106-2, 83-85 cm)

?Monoceratina (Sample 105-2, 143-145 cm)

Upper Aptian: Schuleridea jonesiana (Sample 65-4, 101-103 cm)

Cytherurinae (Sample 63-6, 85-90 cm)

(along with marine Cytheridae and Cyprididae in the different stages and substages). 